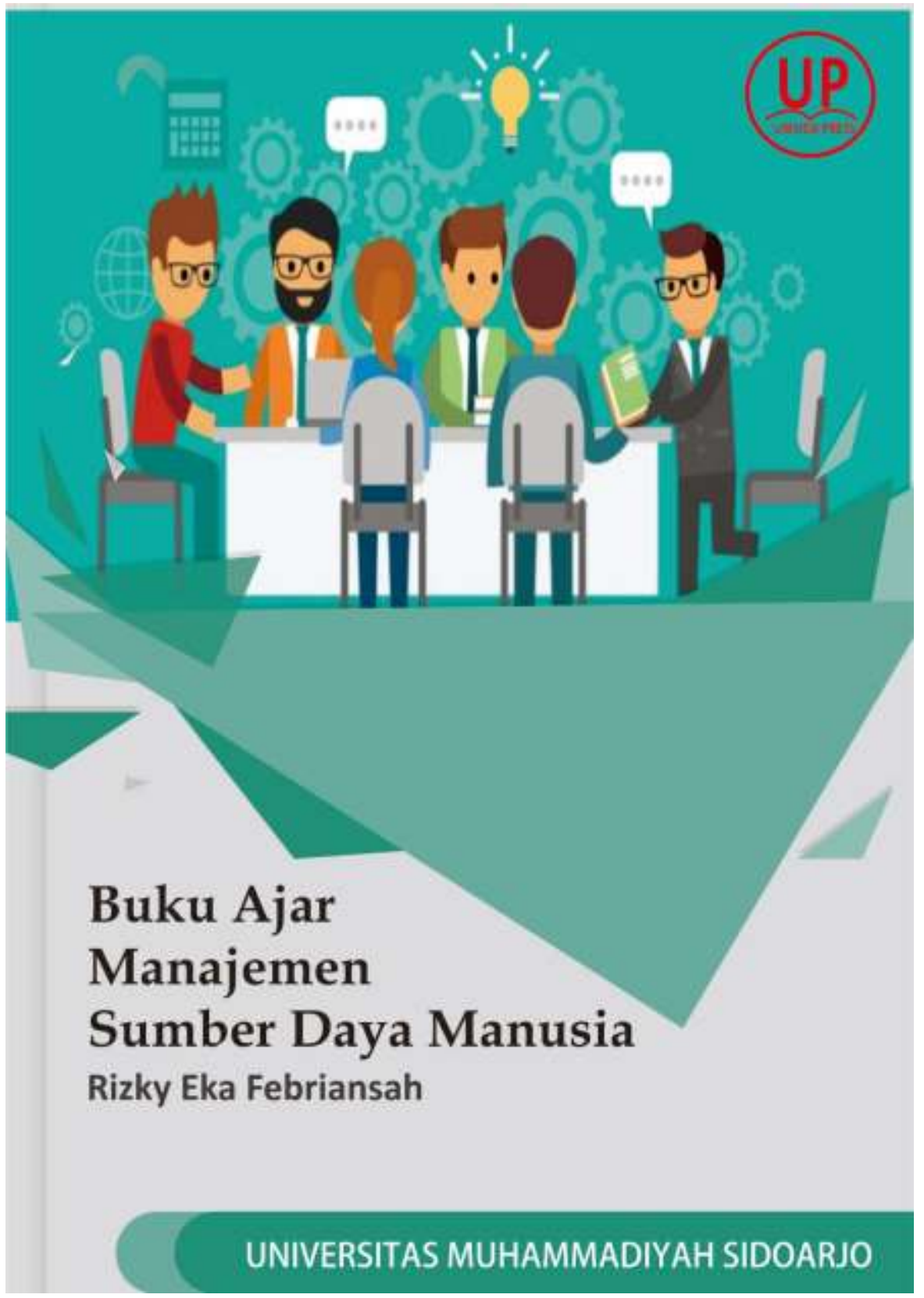




\section{BUKU AJAR \\ MANAJEMEN SDM}

Disusun oleh:

Rizky Eka Febriansah, S.Mb., M.SM

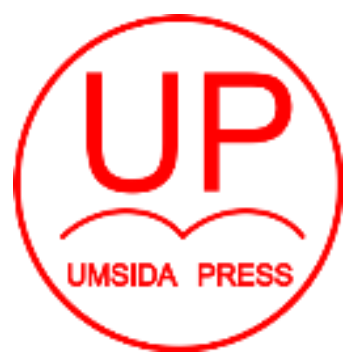

Diterbitkan oleh UMSIDA PRESS

Jl. Mojopahit 666 B Sidoarjo

ISBN: 978-602-5914-26-3

Copyright@2018.

Authors

All rights reserved 


\section{BUKU AJAR}

\section{MANAJEMEN SDM}

\section{Penulis :}

Rizky Eka Febriansah, S.Mb., M.SM

\section{ISBN :}

978-602-5914-26-3

\section{Editor :}

Septi Budi Sartika, M.Pd

M. Tanzil Multazam, S.H., M.Kn.

\section{Copy Editor :}

Fika Megawati, S.Pd., M.Pd.

Design Sampul dan Tata Letak :

Mochamad Nashrullah, S.Pd

\section{Penerbit :}

UMSIDA Press

\section{Redaksi :}

Universitas Muhammadiyah Sidoarjo

Jl. Mojopahit No 666B

Sidoarjo, Jawa TImur

Cetakan pertama, Agustus 2018

(C) Hak cipta dilindungi undang-undang

Dilarang memperbanyak karya tulis ini dengan suatu apapun tanpa ijin tertulis dari penerbit. 


\section{KATA PENGANTAR}

Puji syukur kehadirat Allah SWT atas segala anugerah dan rahmat-Nya, sehingga Buku Ajar Manajemen SDM untuk Fakultas Ekonomi dan Bisnis Universitas Muhammadiyah ini dapat terselesaikan dengan baik.

Buku Ajar Manajemen SDM ini terdiri dari 14 Bab Materi Perkuliahan, yang merupakan satu kesatuan materi yang dipelajari oleh mahasiswa secara menyeluruh dan tak terpisahkan selama satu semester karena merupakan satu kesatuan yang utuh dalam Capaian Kompetensi dari Manajemen SDM di Rencana Pembelajaran Semester .

Tujuan diterbitkan buku ajar ini untuk membantu mahasiswa agar dapat menguasai konsep pengelolaan Sumber Daya Manusia dalam ekonomi dan bisnis secara mudah, dan utuh. Di samping itu pula, buku ajar ini dapat digunakan sebagai acuan bagi dosen yang mengampu mata kuliah Manajemen Sumber Daya Manusia. Isi modul ini memuat 5 komponen utama yaitu; Pendahuluan, Penyajian Materi, Rangkuman, Latihan dan Daftar Pustaka. Buku Ajar Manajemen SDM Ekonomi dan Bisnis ini diterbitkan oleh Universitas Muhammadiyah Sidoarjo (UMSIDA) Press untuk kalangan sendiri. Buku Ajar ini merupakan buku terbitan edisi pertama yang tentunya masih butuh disempurnakan. Oleh karena itu, saran dan masukan oleh para pengguna sangat kami harapkan untuk kesempurnaan isi buku ajar ini di masa yang akan datang.

Sidoarjo, Januari 2018

Penulis

\section{DAFTAR ISI}


Daftar Isi.

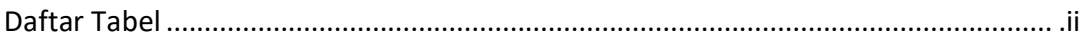

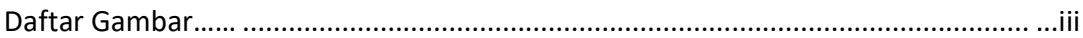

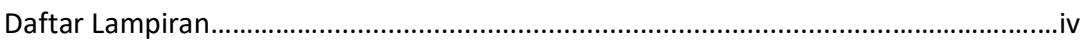

BAB I : Manajemen Sumber Daya Manusia dan Ruang Lingkupnya............................1

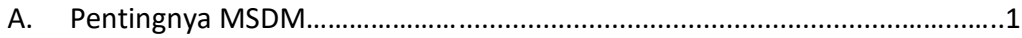
B. Definisi, peranan, dan komponen MSDM.............................................2

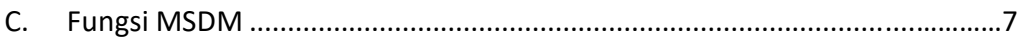

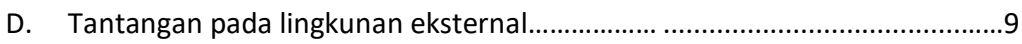
E. Mengintegrasikan SDM dalam keputusan Stratejik................................11

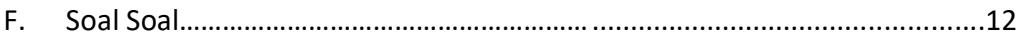

BAB 2 Pengadaaan Sumber Daya Manusia.........................................................13

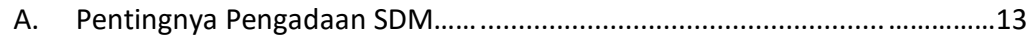

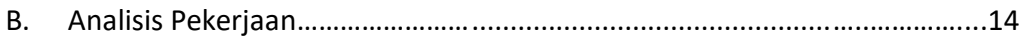

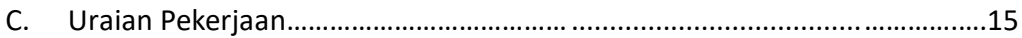

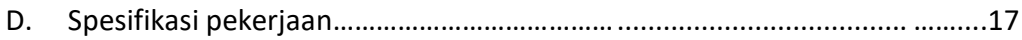

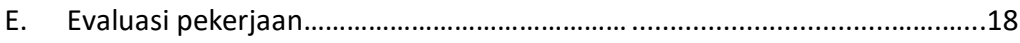

F. Penyederhanaan dan pengayaan kerja....................................................20

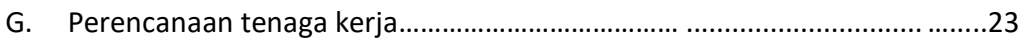

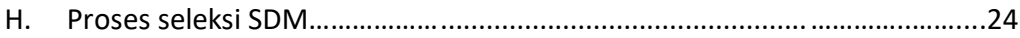

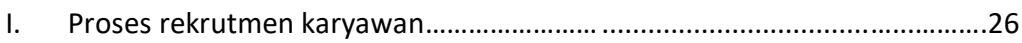

J. Orientasi dan penempatan karyawan ....................................................29

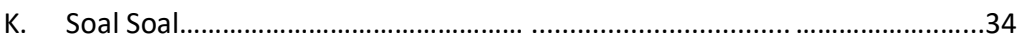


BAB 3: Pengembangan Karyawan

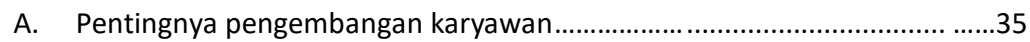

B. Tujuan dan manfaat pengembangan SDM...............................................36

C. Pelatih dalam pengembangan SDM......................................................39

D. Jenis dan teknik dalam pengembangan SDM......................................40

E. Perencanaan karir individu.......................................................

F. Manajemen karir organisasi....................................................48

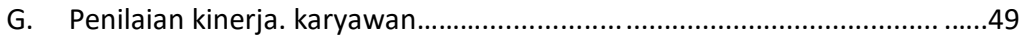

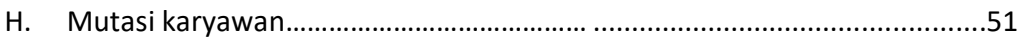

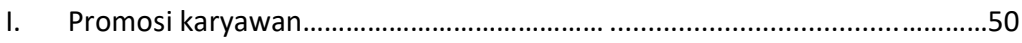

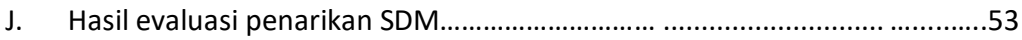

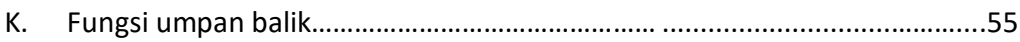

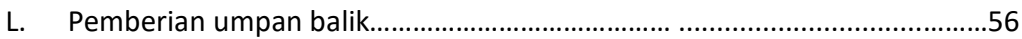

M. Keterkaitan prestasi dengan kompensasi stratejik................................59

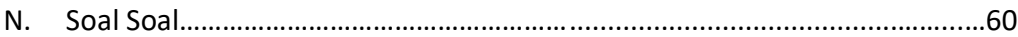

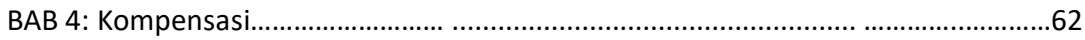
A. Pentingnya kompensasi. .62
B. Jenis dan Pembagian kompensasi... .64
C. Sistem dan kebijaksanaan kompensasi .68
D. Faktor yang mempengaruhi besar kecilnya kompensasi...... 76
E. Soal Soal. . .78

BAB 5 : Pengintegrasian Sumber Daya Manusia .79

A. Pentingnya pengintegrasian sumber daya manusia..............................79

B. Hubungan antar manusia .81 


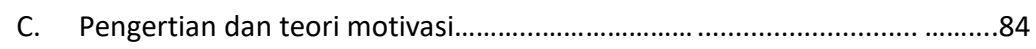

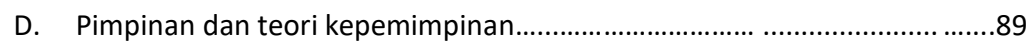

E. Kesepakatan kerja bersama dan collective bargaining..............................91

F. Hubungan pemberian kompensasi individu untuk meningkatkan

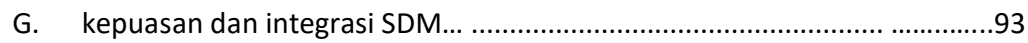

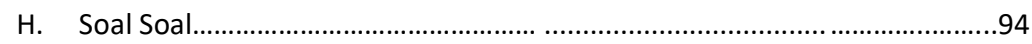

BAB 6 : Pemeliharaan Sumber Daya Manusia ..........................................................96
A. Pentingnya pemeliharaan SDM........................................................96

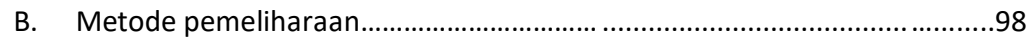

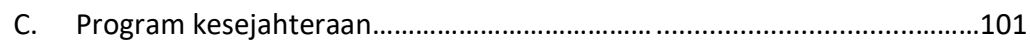
D. Keselamatan dan kesehatan kerja (K3) ...........................................103

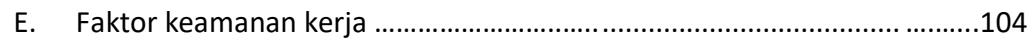

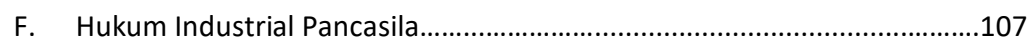

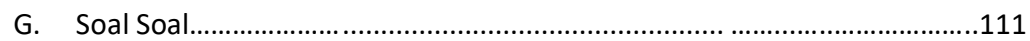

BAB 7 : Perencanaan Sumber Daya Manusia .......................................................112
A. Pentingnya perencanaan sumber daya manusia....................................112
B. Metode, informasi, dan peramalan SDM.............................................115
C. Prosedur dan perencanaan SDM...........................................................117

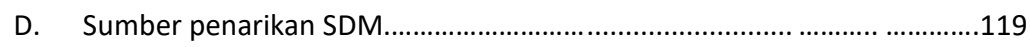

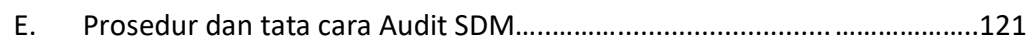

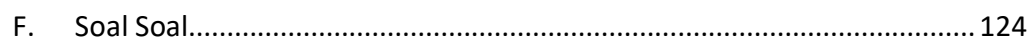

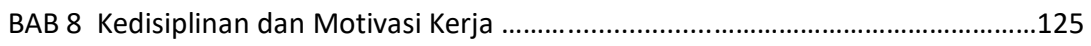

A. Pentingnya kedisiplinan dan motivasi kerja.......................................125 


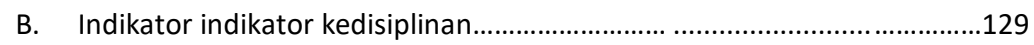

C. Persaingan dan konflik dalam organisasi..................................................132

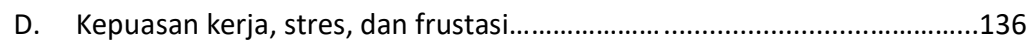

E. Bimbingan konseling karyawan untuk meningkatkan kedisiplinan.................................................................138

F. Menejemen performa untuk meningkatkan

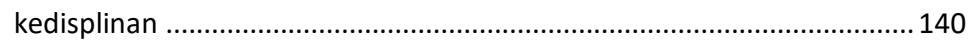

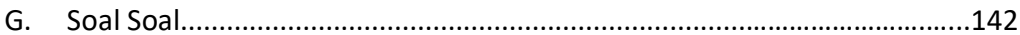

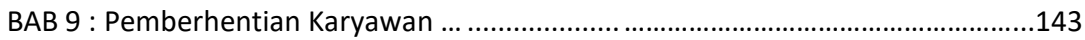

A. Pentingnya pemberhentian tenaga kerja..............................................143

B. Alasan alasan dalam pemberhentian......................................................144

C. Menjelaskan proses pemberhentian......................................................147

D. Undang Undang dan konsep pemberhentian......................................150

E. Pemberian uang pesangon dan menentukan

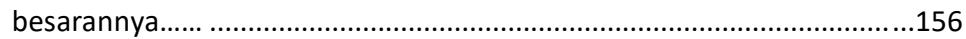

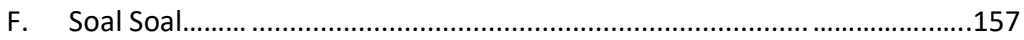

BAB 10 : Pengelolaan Tunjangan Sumber Daya Manusia ......................................158

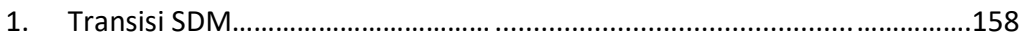

2. Perspektif strategis pengelolaan tunjangan..........................................159

3. Jenis tunjangan waktu bekerja ..............................................................162

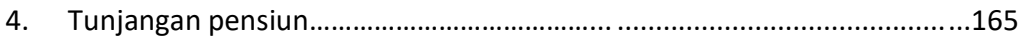

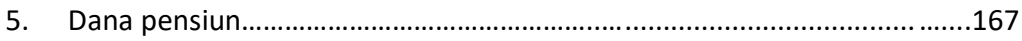

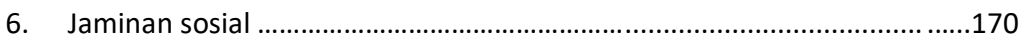

7. Tunjangan perawatan kesehatan..........................................................172

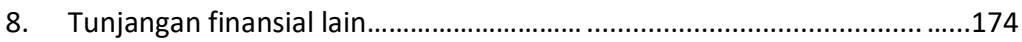

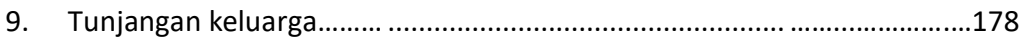




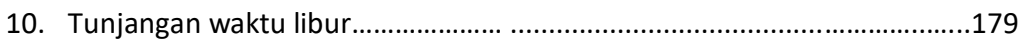

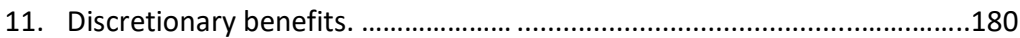

12. Administrasi tunjangan......................................................................181

13. Perspektif stratejik kompensasi untuk menghasilkan komitmen Karyawan........................................................................182

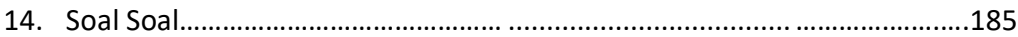

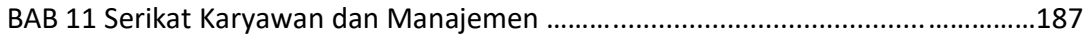

A. Sejarah dan awal mula munculnya serikat kerja....................................187

B. Kerangka hubungan antara serikat karyawan, manajemen, dan pemerintah .................................................................189

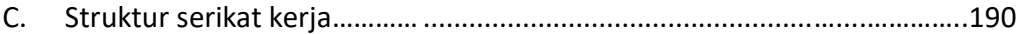

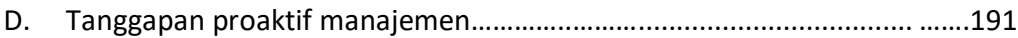

E. Penyelesain dan mediasi konflik antara serikat kerja dan manajemen....................................................................193

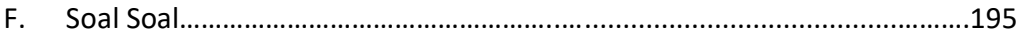




\section{DAFTAR PUSTAKA}

Aguinis, Herman. (2013). Performance Management. Edisi Internasional Cetakan Ketiga. Singapura: Pearson.

Handoko, T. Hani. (2012). Manajemen Personalia dan Sumberdaya Manusia. Edisi Kedua Cetakan 19. Yogyakarta: BPFE.

Hasibuan, Malayu. (2016). Manajemen Sumber Daya Manusia. Edisi Revisi Cetakan 19. Jakarta: Bumi Aksara.

Mangkuprawira, Sjafri. (2011). Manajemen Sumber Daya Manusia Stratejik. Edisi Kedua. Bogor: Ghalia Indoesia.

Martochhio, Joseph. (2013). Strategic Compensation from Human Resource Management Approach. Edisi Internasional Cetakan Ketiga. Singapura: Pearson.

Mathis, Robert \& Jackson, John. (2012). Manajemen Sumber Daya Manusia. Edisi Bahasa Inggris. Buku 2. Jakarta: Salemba Empat.

Mello, Jeffrey. (2011). Strategic Management of Human Resources. Edisi Internasional Cetakan Ketiga. Singapura: Cengage Learning.

Wibowo. (2016). Manajemen Kinerja. Edisi Kelima Cetakan 10. Jakarta: Rajawali Pers. 


\section{Manajemen Sumber Daya Manusia dan Ruang Lingkupnya}

\section{A. Pentingnya Manajemen SDM}

MSDM adalah ilmu dan seni mengatur hubungan dan peranan tenaga kerja agar efektif dan efisien membantu terwujudnya tujuan perusahaan, karyawan dan masyarakat. Unsur-unsur manajemen terdiri dari man, money, method, materials, machines, dan market disingkat $6 \mathrm{M}$.

Unsur men (manusia) berkembang menjadi suatu bidang ilmu manajemen sumber daya manusia atau MSDM yang merupakan terjemahan dari man power management. MSDM adalah suatu bidang manajemen yang khusus mempelajari hubungan dan peranan manusia dalam perusahaan. Dengan demikian, fokus yang dipelajari dari MSDM hanyalah masalah yang berhubungan dengan tenaga kerja manusia saja.

Manusia selalu berperan aktif dan dominan dalam setiap kegiatan organisasi, karena manusia menjadi perencana, pelaku dan penentu terwujud tujuan organisasi. Secanggih atau semutakhir apapun peralatan yang dimiliki perusahaan 
tidak akan ada manfaatnya bagi perusahaan jika peran aktif karyawan tidak diikutsertakan.

\section{B. Peranan dan Komponen MSDM}

Terdapat 3 Komponen utama dalam manajemen sumber daya manusia yaitu pengusaha, karyawan, dan pemimpin/manajer.

\section{Pengusaha (Bussinessman)}

Pengusaha adalah setiap individu atau kelompok yang menginvestasikan modalnya untuk mendapatkan pendapatan (income) dan besarnya pendapatan tersebut tidak stabil atau tidak menentu. Hal tersebut sebanding dengan laba yang dicapai perusahaan tersebut.

\section{Karyawan}

Dalam manajemen sumber daya manusia karyawan atau staff atau worker adalah inti utama dari sebuah perusahaan. Karyawan merupakan kekayaan utama suatu perusahaan, karyawan berperan aktif dalam menetapkan rencana, sistem, proses dan tujuan yang ingin digapai oleh suatu perusahaan. Karyawan adalah penjual jasa yaitu pikiran dan tenaganya dengan 
imbalan yang telah ditetapkan sebelum dia bekerja. Terdapat dua jenis karyawan berdasarkan posisinya dalam perusahan yaitu:

a) Karyawan Operasional: Pengertian karyawan operasional adalah setiap individu yang secara langsung harus mengerjakan sendiri pekerjaannya sesuai dengan arahan dan perintah atasan

b) Karyawan Manajerial: Pengertian karyawan manajerial adalah setiap orang yang berhak mengatur dan mengendalikan dan memerintah bawahannya untuk melakukan pekerjaannya dan dikerjakan sesuai dengan perintah. Karyawan manajerial terbagi atas dua lagi yaitu manajer lini dan manajer staf.

\section{Pemimpin /Manajer}

Pemimpin adalah seseorang yang memiliki wewenang dan menggunakannya untuk mengarahkan, memerintahkan, mengontrol orang lain dan juga secara langsung bertanggungjawab atas pekerjaan yang dilakukan oleh orang tersebut dalam mencapai tujuan bersama. 
Manajemen seperti yang kita ketahui adalah ilmu yang memberikan kita pengetahuan tentang cara cara menyelesaikan masalah dan mencapai tujuan menggunakan orang lain. Oleh karenanya, anda perlu mengetahui peranan MSDM sehingga anda paham pentingnya sumber daya manusia, yang notabenenya merupakan inti dari manajemen itu sendiri.

Berikut beberapa peranan MSDM :

1. Menentukan dan menetapkan penarikan, seleksi, dan penempatan karyawan berdasarkan asas the right man in the right job.

2. Menentukan dan menetapkan jumlah, kualitas, dan penempatan tenaga kerja yang meliputi dengan kebutuhan perusahaan berdasarkan job description (deksripsi kerja), job specification (spesifikasi pekerjaan), job requirement (kebutuhan pekerjaan), dan terakhir job evaluation (evaluasi kerja).

3. Menentukan dan menetapkan program kesejahteraan, pengembangan, promosi dan pemberhentian. 
4. Memproyeksikan atau memprediksi penawaran dan permintaan sumber daya manusia (SDM) pada masa yang akan datang.

5. Memprediksi situasi perekonomian pada umumnya dan perkembangan perusahaan pada khususnya.

6. Mengawasi dengan cermat undang undang perburuhan dan kebijaksaan pemberian balas jasa perusahaan perusahaan sejenis.

7. Mengawasi kemajuan serikat buruh dan perkembangannya

8. Melaksanakan pendidikan, latihan, dan penilaian prestasi karyawan.

9. Mengatur dan mengendalikan mutasi karyawan baik secara vertikal maupun horizontal.

10. Mengatur pensiun, pemberhentian dan pesangonnya.

\section{Fungsi MSDM}

Hasibuan (2003:21), menjelaskan secara singkat fungsifungsi manajemen sebagai berikut:

1. Perencanaan (Planning). Merencanakan tenaga kerja secara efektif dan efisien agar sesuai dengan kebutuhan perusahaan dalam mewujudkan tujuan. 
2. Pengorganisasian (Organizing). Menyusun suatu organisasi dengan mendesain struktur dan hubungan antara tugas-tugas yang harus dikerjakan oleh tenaga kerja yang dipersiapkan.

3. Pengarahan (Directing). Kegiatan mengarahkan semua karyawan agar mau bekerjasama dan bekerja secara efektif dan efisien dalam membantu tercapainya tujuan perusahaan, karyawan, dan masyarakat.

4. Pengendalian (Controlling). Kegiatan mengendalikan semua karyawan agar mentaati peraturan-peraturan perusahaan dan bekerja sesuai dengan rencana.

5. Pengadaan Tenaga Kerja (Procurement). Proses penarikan, seleksi, penempatan, orientasi, dan induksi untuk mendapatkan karyawan yang sesuai dengan kebutuhan perusahaan.

6. Pengembangan (Development). Proses peningkatan keterampilan teknis, teoritis, konseptual, dan moral karyawan melalui pendidikan dan pelatihan.

7. Kompensasi (Compensation). Pemberian balas jasa langsung (direct), dan tidak langsung (indirect), uang 
atau barang kepada karyawan sebagai imbalan jasa yang diberikan kepada perusahaan.

8. Pengintegrasian (Integration). Kegiatan untuk mempersatukan kepentingan perusahaan dan kebutuhan karyawan, agar tercipta kerjasama yang serasi dan saling menguntungkan.

9. Pemeliharaan (Maintenance). Kegiatan untuk memelihara atau meningkatkan kondisi fisik, mental, dan loyalitas karyawan agar mereka mau bekerja sama sampai pensiun.

10. Kedisiplinan (Discipline). Keinginan dan kesadaran untuk mentaati peraturan-peraturan perusahaan dan norma - norma sosial.

11. Hubungan Tenaga Kerja (Separation). Putusnya hubungan kerja seseorang dari suatu perusahaan.

\section{Tantangan MSDM Pada Lingkungan Internal}

Departemen SDM sering kali menghadapi tantangan dari dalam organisasi yang dilayaninya. Tantangan tersebut muncul karena perusahaan mengejar sasaran ganda. Sasaran tersebut memerlukan "trade-offs" antara tujuan finansial, 
pemasaran, produksi, dan personalia. Beberapa tantangan internal adalah:

a. Karakter Organisasi, merupakan produk semua ciri organisasi: orang-orangnya, tujuan-tujuannya, struktur organisasi, tehnologi, peralatan yang digunakan, kebijakan, ukuran, umur, keberhasilan dan kegagalannya. Jadi, dalam menyusun rencana dan kebijakan personalia, MSDM harus menyesuaikan dengan karakter tersebut.

b. Serikat Karyawan, mempunyai tantangan nyata bagi organisasi yang memiliki organisasi buruh, dan tantangan potensial bagi yang tidak memiliki serikat karyawan. Dalam perusahaan yang mempunyai serikat karyawan, manajemen dan serikat mengadakan perjanjian kerja yang mengatur berbagai prasyarat kerja yang berpotensi membatasi kebijakan manajemen SDM.

c. Sistem Informasi, kualitas kontribusi Manajemen SDM tergantung pada kualitas informasiyang digunakan sebagai pengambilan keputusan.

d. Perbedaan Individual Karyawan, misal perbedaan kepribadian, phisik, bakat dan intelegensia. 
e. Sistem Nilai Manajer dan Karyawan, berbagai sistem nilai dan norma yang dianuut para manajer dan karyawan merupakan kendala tambahan yang dihadapi Manajemen SDM.

\section{E. Tantangan MSDM Pada Lingkungan Eksternal}

Organisasi dikelilingi oleh suatu lingkungan eksternal yang terdiri dari beberapa variabel, yang sebagian besar tidak dapat dikendalikan. Keputusan dan kebijakan MSDM harus diambil dengan memperhatikan kekuatan eksternal tersebut, seperti:

a. Tantangan Teknologi; bertdampak melalui 2 cara : (1). Dampak yang merubah industri secara keseluruhan, misal kemajuan transportasi dan komunikasi meningkatkan mobilitas angkatan kerja. (2). Otomatisasi, misalnya penggunaan komputer dalam perusahaan.

b. Tantangan Ekonomi; perubahan ekonomi berdampak pada : permintaan akan karyawan baru, tumbuh dan berkembangnya program-program pelatihan. Dari perubahan tersebut berdampak pada perusahaan adalah peningkatan kerja, penawaran benefit yang baik, dan perbaikan kondisi kerja. 
c. Keadaan Politik dan Pemerintah; misalnya kebijakan pemerintah tentang UMP (upah minimum propinsi), keputusan tentang PHK, dan lainnya.

d. Tantangan Demografis; misalnya perubahan tingkat pendidikan, umur, persentase penduduk yang termasuk angkatan kerja.

e. Geografis; misalnya perusahaan yang berlokasi di daerah terpencil, akan mempengaruhi tingkat kompensasi karyawan.

f. Sosial Budaya; misalnya banyaknya partisipasi tenaga kerja wanita, banyaknya orang dengan mudah memperoleh pendidikan.

g. Pasar Tenaga Kerja; ada 3 faktor yang mempengaruhi kegiatan pemenuhan kebutuhan personalia perusahaan, yaitu: (1). Reputasi perusahaan dimata angkatan kerja, (2). Tingkat pertumbuhan angkatan kerja, (3). Tersedianya tenaga kerja dengan pengetahuan dan ketrampilan yang dibutuhkan.

h. Kegiatan Para Pesaing; misalnya pembajakan para manajer, kenaikan gaji/tahun di suatu bank akan berpengaruh pada bank-bank lainnya. 


\section{F. Mengintegrasikan MSDM Dengan Keputusan Stratejik}

Di kalangan praktisi dan akademisi sumberdaya manusia, istilah Manajemen Sumber Daya Manusia (MSDM) Stratejik digunakan untuk mengisyaratkan adanya pemahaman dan kebutuhan bahwa kegiatan MSDM yang diaplikasikan seharusnya dapat memberi kontribusi pada terlaksananya bisnis yang efektif. Keterkaitan antara aktifitas MSDM, kebutuhan bisnis, dan efektifitas perusahaan adalah inti suatu sudut pandang yang disebut MSDM Stratejik. Dua hipotesis yang digunakan dalam MSDM Stratejik adalah: (1) efektifitas MSDM memerlukan suatu pemahaman tentang pentingnya perpaduan MSDM dengan tujuan stratejik organisasi, dan (2) efektifitas MSDM yang mengarah pada perbaikan kinerja organisasi.

Esensi tujuan dari MSDM Stratejik adalah terwujudnya daya saing bisnis maka model MSDM stratejik sangat membutuhkan program-program pengembangan dan pengaplikasian SDM berbasis kompetensi. Para karyawan, baik karyawan manajerial maupun operasional, perlu dikembangkan kompetensinya sesuai dengan tuntutan pasar. Dan untuk itu maka organisasi selayaknya mampu 
mengaktifkan dirinya sebagai learning organization dengan segala prinsipnya yang antara lain berupa adanya proses pembelajaran secara berkelanjutan dan setiap kebijakan bisnisnya berbasis sains / ilmu pengetahuan.

MSDM Stratejik dalam praktiknya dikarakteristikkan oleh adanya (1) integrasi vertikal, yaitu memahami organisasi dan konteksnya; (2) integrasi horisontal, yakni menciptakan sistem msdm yang koheren; (3) menunjukkan keefektifan, mengungkapkan bagaimana sistem MSDM mempengaruhi kinerja organisasi; dan (4) kemitraan, para profesional sumber daya manusia bersinergi secara apik dalam pelaksanaan tugasnya, baik dengan manajer lini ataupun dengan karyawan non-manajerial.

\section{G. Soal Soal}

1. Jelaskan pentingnya peranan MSDM!

2. Apakah Unsur MSDM itu?

3. Masalah apa saja yang akan dihadapi MSDM dalam menjalankan kebijakannya pada sebuah organisasi?

4. Masalah apa saja yang dibahas dalam MSDM?

5. Jelaskan 4 faktor yang mencirikan MSDM stratejik! 


\section{Pengadaan}

\section{Sumber Daya Manusia}

\section{A. Pentingnya Pengadaan SDM}

Pengadaan adalah mekanisme dari perekrutan, seleksi, penempatan, orientasi dan induksi untuk mendapatkan karyawan yang efektif dan efisien dalam membantu tercapainya tujuan perusahaan. Pengadaan (procurement) adalah fungsi operasional pertama MSDM. Pengadaan karyawan merupakan masalah yang penting dan kompleks karena untuk mendapatkan dan menempatkan orang orang yang kompeten dan bisa saling bekerja sama dengan individu lainnya tidaklah semudah membeli dan menempatkan mesin.

Tenaga kerja adalah aset utama organisasi yang menjadi perencana dan pemeran aktif dari setiap kegiatan organisasi. Mereka mempunyai daya pikir, perasaan, kebutuhan, status, latar pendidikan, usia, dan gender yang heterogen yang dibawa kedalam perusahaan. Karyawan yang cakap, pandai, dan terampil belum menjamin performa kerja yang baik jika moril kerja dan kedisiplinannya rendah. Mereka baru bermanfaat dan menunjang terwujudnya tujuan perusahaan 
jika mereka memiliki keinginan tinggi untuk berprestasi. Karyawan yang, kurang cakap, kurang kapabel, dan kurang terampil mengakibatkan pekerjaan tidak terselesaikan tepat pada waktunya. Kuantitas dan kualitas karyawan harus sesuai dengan kebutuhan organisasi, agar efektif dan efisien dalam menunjang tercapainya tujuan.

\section{B. Analisis Pekerjaan}

Analisis jabatan/pekerjaan (job analysis) sebagai bagian dari pengadaan MSDM dalam sebuah organisasi merupakan suatu penentuan dari isi suatu jabatan yang melingkupi tugas, tanggung jawab, dan hubungan dengan individu atau bagian lain dalam organisasi, serta persyaratan yang dibutuhkan agar seorang karyawan mampu melaksanakan tugas pekerjaan dalam jabatan yang dipangkunya dengan baik. Melalui analisis jabatan akan diperoleh beragam ukuran yang merupakan basis bagi kegiatan-kegiatan dalam fungsi manajemen lainnya.

Analisis jabatan dibutuhkan untuk mengumpulkan informasi-informasi guna merumuskan deskripsi pekerjaan (job description), spesifikasi pekerjaan (job specification), dan evaluasi pekerjaan (job evaluation). Analisis jabatan memiliki keterkaitan dengan berbagai peran dari manajemen sumber 
daya manusia, karena dapat menghasilkan deskripsi jabatan atau pekerjaan yang memuat gambaran mengenai isi dari sebuah jabatan baik yang menyangkut tugas dalam pekerjaan (assignment), standar kinerja (performance standard), bobot jabatan (job value), maupun persyaratan pemangku jabatan (job specification) yang akan dapat digunakan sebagai dasar untuk melaksanakan pekerjaan dalam lingkup penarikan karyawan (recruitment).

Analisis pekerjaan juga meiliki fungsi dalam menghasilkan penilaian kinerja (performance appraisal) yang adil dan objektif. Penilaian kinerja adalah perbandingan antara standar kinerja (performance standard) dengan kenyataan kinerja (actual performance) karyawan yang dapat menjadi dasar penentuan keputusan MSDM dalam pemberian pengembangan (development) kompensasi, (compensation), atau promosi jabatan (promotion) bagi karyawan.

\section{Uraian Pekerjaan}

Uraian Pekerjaan / Deskripsi Jabatan / Job Description adalah paparan yang mencakup pekerjaan dasar dari suatu jabatan yang termasuk tugas, wewenang, tanggung jawab dan informasi-informasi penting lainnya yang melekat pada 
jabatan tersebut. Contoh Informasi-informasi dalam deskripsi jabatan tersebut diantaranya seperti nama Jabatan, lokasi dan lingkungan pekerjaan, informasi pelaporan, ringkasan pekerjaan, sifat dan tujuan pekerjaan, tugas-tugas yang harus dilakukan, kondisi kerja, mesin dan peralatan yang bisa digunakan dalam penyelesaian kerja, serta bahaya dan risiko yang terlibat didalam pekerjaan tersebut.

Tujuan dalam pembuatan uraian pekerjaan adalah:

1. Menghimpun data pekerjaan yang berkaitan dengan jabatan yang bersangkutan untuk memudahkan karyawan memahami tugas pokok dan fungsinya.

2. Memberikan pandangan yang jelas mengenai jenis kandidat yang dibutuhkan oleh departemen / divisi tertentu dalam menjalankan tugas dan pekerjaan di departemen / divisi tersebut.

3. Untuk menginformasikan ke karyawan mengenai bagaimana standar prestasi karyawan tersebut dinilai, rentang komunikasi dalam pekerjaan, serta hak yang didapat dan kewajiban yang harus dipenuhi jika terpilih untuk menjabat di posisi pekerjaan tersebut. 


\section{Spesifikasi Pekerjaan}

Spesifikasi Jabatan (Job Specification) atau dikenal dengan spesifikasi karyawan adalah pernyataan tertulis mengenai kualifikasi pendidikan, tingkat pengalaman, pengetahuan dan kecakapan kerja, keterampilan fisik, kestabilan emosional, persyaratan teknis dan kemampuan komunikasi yang diperlukan untuk melakukan pekerjaan dan tanggung jawab yang terlibat dalam pekerjaan. Spesifikasi Jabatan juga melingkupi persyaratan kesehatan fisik, kesehatan mental, kecerdasan, bakat, daya ingat, kepemimpinan, kemampuan beradaptasi, fleksibilitas, perilaku, kreativitas, etika, dan status karyawan.

Tujuan dalam pembuatan spesifikasi jabatan adalah:

1. Spesifikasi jabatan menolong kandidat (pelamar) menganalisis apakah dirinya memenuhi persyaratan yang dibutuhkan untuk mengisi lowongan pekerjaan tertentu atau tidak.

2. Spesfikasi Jabatan dapat mendukung tim rekrutmen perusahaan untuk memahami apakah kandidat yang melamar telah memenuhi tingkat kualitas, kualifikasi, 
karakteristik, dan persyaratan lainnya untuk mengisi jabatan yang dibutuhkan oleh organisasi.

3. Spesifikasi Jabatan memberikan informasi terperinci mengenai tanggung jawab, keterampilan fisik dan teknik yang diinginkan, dan kemampuan dalam berkomunikasi untuk melakukan dan menyelesaikan pekerjaan tertentu.

4. Spesifikasi Jabatan membantu perusahaan dalam memilih kandidat yang paling tepat, apakah dari sumber internal atau sumber eksternal, dalam mengisi jabatan lowong yang dibutuhkan oleh perusahaan.

\section{E. Evaluasi Pekerjaan}

Evaluasi pekerjaan atau penilaian kinerja adalah tindakan pengukuran yang dilakukan pimpinan / manajer yang dilakukan secara sistematis untuk menentukkan apakah seorang karyawan melakukan pekerjaannya sesuai dengan tugas dan tanggung jawabnya di sebuah periode tertentu. Hasil evaluasi tersebut digunakan sebagai umpan balik yang memberikan informasi tentang hasil pekerjaan karyawan dan kinerja organisasi. Disamping itu, juga digunakan untuk menentukan kebutuhan pengembangan secara tepat, 
memberikan tanggung jawab yang pantas kepada karyawan sehingga dapat melaksanakan pekerjaan dengan lebih baik di masa depan, dan sebagai basis untuk menentukan kebijakan dalam hal promosi jabatan atau penentuan kompensasi.

Tujuan evaluasi pekerjaan adalah untuk membenahi atau menaikkan kinerja organisasi melalui peningkatan performa dari SDM perusahaan. Secara lebih spesifik, tujuan dari evaluasi pekerjaan adalah:

1. Meningkatkan saling pengertian dan komunikasi antara karyawan tentang persyaratan kerja.

2. Menyimpan dan mengakui hasil kerja seorang karyawan, sehingga mereka lebih termotivasi untuk bekerja dengan lebih baik

3. Memberikan kesempatan kepada karyawan untuk mendiskusikan keinginan dan aspirasinya serta meningkatkan kepedulian terhadap karier atau pekerjaan yang di embannya sekarang.

4. Mendefinisikan atau menyusun kembali sasaran di masa depan, sehingga karyawan terdorong untuk berprestasi sesuai dengan kapasitasnya. 


\section{F. Penyederhanaan dan Pengayaan Kerja}

Penyederhanaan pekerjaan adalah penerapan secara terencana dari logika untuk menemukan cara yang lebih mudah dan lebih baik untuk melaksanakan sesuatu tugas/pekerjaan untuk menghilangkan pemborosan dalam bentuk waktu, tenaga, uang, kerja, material, alat dan sebagainya.

Penyederhaan pekerjaan bertujuan untuk menghasilkan spesialisasi yang lebih mendetail dalam pelaksanaan pekerjaan di perusahaan tersebut. hal Ini berarti pekerjaan disederhanakan. Tugas yang ada dalam pekerjaan dibagi menjadi dua. Pekerjaan yang masih ada berisi tugas-tugas yang lebih sedikit.

Simplifikasi pekerjaan ini mengakibatkan hal-hal berikut :

a. Struktur organisasi di perusahaan semakin melebar.

b. Pekerjaan menjadi terlalu spesialisasi, sehingga mengakibatkan kebosanan yang pada gilirannya menimbulkan kesalahan dalam pekerjaan atau bahkan menyebabkan turnover yang tinggi.

c. Karyawan semakin produktif sehingga keuntungan ekonomis dari spesialisasi akan didapat. 
Pengayaan pekerjaan ialah perluasan pekerjaan dan tanggung jawab secara vertikal yang akan dikerjakan seseorang karyawan dalam jabatannya. Perluasan pekerjaan ini melambangkan suatu transisi / perubahan yang direncanakan (planned-change) pada bermacam kegiatan pekerjaan untuk memberikan variasi yang lebih tinggi kepada seseorang karyawan yang memiliki pengetahuan dan ketrampilan yang lebih baik. Perluasan secara vertikal dilakukan untuk memberikan kepuasan lebih besar pada karyawan dan peluang bagi pengembangan pribadinya. Para karyawan diberi kesempatan untuk terlibat aktif dalam kegiatan manajerial pekerjaan mereka disamping operasionalnya.

Pengayaan pekerjaan tidak hanya berguna bagi karyawan, tapi juga menguntungkan perusahaan. Keuntungan tersebut dapat dilihat dari 5 dimensi yang dikembangkan oleh Greenberg \& Baron, yaitu:

1. Keberagaman keterampilan (skill variety). Makin banyak ragam keterampilan yang digunakan oleh karyawan dalam pelaksanaan kerjanya, pekerjaan 
akan semakin menantang dan dapat mengurangi tingkat kebosanan.

2. Jati diri tugas (task identity). Tingkat sejauh mana penyelesaian pekerjaan secara keseluruhan dapat dilihat hasilnya dan dapat dikenali sebagai hasil kinerja seseorang. Seorang karyawan akan lebih mudah mendapatkan kepuasan kerja saat ia menyelesaikan sebuah tugas yang menyeluruh tetapi masih tetap saling berkaitan.

3. Tugas yang penting (task significance). Tingkat sejauh mana sebuah pekerjaan memiliki dampak yang signifikan bagi kehidupan orang lain, baik rekan kerja di dalam perusahaan yang sama maupun orang lain di lingkungan eksternal organisasi. Jika tugas dirasakan penting dan berarti oleh karyawan, maka ia cenderung lebih termotivasi dalam menyelesaikan pekerjaannya dengan baik.

4. Otonomi. Tingkat kebebasan karyawan dalam melaksanakan pekerjaannya, yang mempunyai pengertian bahwa karyawan tidak bergantung pada individu lain serta memiliki keleluasaan dalam menuntaskan pekerjaan dan memutuskan prosedur 
apa yang akan digunakan untuk menyelesaikannya. Semakin tinggi tingkat otonomi yang dimiliki karyawan, semakin tinggi kepuasan kerja yang ia peroleh.

5. Umpan balik (feedback). Memberikan informasi kepada karyawan tentang hasil pekerjaan mereka sehingga karyawan dapat segera memperbaiki kualitas dan kinerja pekerjaan.

\section{G. Perencanaan Tenaga Kerja}

Perencanaan tenaga kerja adalah proses penyusunan rencana ketenagakerjaan secara sistematis yang dijadikan dasar dan acuan dalam penyusunan kebijakan, stategi, dan pelaksanaan program pembangunan ketenagakerjaan yang berkesinambungan. Hasibuan, mengutip pula pendapat Dale Yoder, Menyimpulkan bahwa perencanaan tenaga Kerja, memuat hal hal sebagai berikut:

1) Penggunaan tenaga kerja yang efektif

2) Peramalan perkiraan kebutuhan SDM organisasi

3) Pengembangan kebijakan dan program untuk memenuhi kebutuhan karyawan

4) Mereview dan mengawasi kinerja karyawan 
Selanjutnya, dikatakan bahwa sasaran perencanaan tenaga kerja adalah untuk memastikan bahwa organisasi :

a) Mendapatkan dan mempertahankan kuantitas dan kualitas tenaga kerja yang diperlukan.

b) Mampu mengantisipasi masalah-masalah yang muncul dari potensi kelebihan atau kekurangan tenaga kerja.

\section{H. Proses Seleksi MSDM}

Seleksi MSDM dilakukan oleh perusahaan untuk memperoleh karyawan yang berkualifikasi dan berkompeten yang akan menjabat serta mengerjakan semua tugas pada perusahaan. Seleksi adalah suatu kegiatan pemilihan dan penentuan pelamar yang akan diterima atau ditolak untuk menjadi karyawan perusahaan. Seleksi ini didasarkan kepada spesifikasi tertentu dari setiap perusahan bersangkutan.

Secara umum, tujuan seleksi adalah:

1. Mendapatkan para karyawan yang qualified dan memiliki keahlian sebagaimana yang dibutuhkan oleh perusahaan. 
2. Menimbang kemampuan calon karyawan atau pelamar, apakah ia dapat menyelesaikan pekerjaan tertentu yang disyaratkan.

3. Untuk menyediakan dan membangun kader-kader karyawan yang dapat menunjang kegiatan organisasi di masa yang akan datang.

Dalam seleksi SDM, terdapat dua metode yang telah dikenal secara luas yaitu:

a. Metode non ilmiah, yaitu seleksi yang dilakukan tidak didasarkan kepada standar, kriteria, atau spesifikasi kebutuhan nyata pekerjaan, tetapi hanya didasarkan kepada pengalaman dan perkiraan saja. Seleksi ini biasanya tidak berpedoman kepada uraian pekerjaan dan spesifikasi pekerjaan dari jabatan yang akan diisi. Unsur-unsur yang diseleksi biasanya meliputi; 1) surat lamaran, 2) ijazah terakhir dan transkrip nilai, 3) surat keterangan dan pengalaman kerja, 4) rekomendasi / referensi dari pihak yang dapat dipercaya, 5) walk interview, 6) keadaan dan penampilan fisik, 7) keturunan dari pelamar, dan 8) gaya tulisan pelamar. 
b. Metode ilmiah, yaitu seleksi dengan memasukkan analisis cermat tentang unsur-unsur yang akan diseleksi supaya diperoleh karyawan yang kompeten dengan penempatan yang tepat. Seleksi ilimah dilakukan dengan cara berikut; 1) metode kerja yang jelas dan terstruktur, 2) berorientasi kepada performa kerja, 3) berorientasi kepada kebutuhan riil perusahaan, 4) berdasarkan kepada job analysis, dan 5) berpegang kepada undang-undang perburuhan.

\section{Proses Rekrutmen Karyawan}

Setiap perusahaan ataupun organisasi memiliki proses dan prosedur dalam penyeleksian karyawan baru. Berikut ini adalah proses rekrutmen karyawan baru pada umumnya.

1) Wawancara awal (preliminary interview). Proses wawancara awal bertujuan untuk mengeliminasi para pelamar yang tidak memenuhi persyaratan yang diinginkan oleh organisasi berdasarkan data dan informasi yang disodorkan oleh pelamar kerja. Dalam wawancara awal ini, para pelamar akan diberikan deskripsi singkat mengenai organisasi dan pekerjaan yang terkait. 
2) Pengujian seleksi (selection test). Calon karyawan yang dinyatakan lulus pada proses wawancara awal akan diuji untuk menilai seberapa cakap pelamar tersebut mampu melakukan pekerjaan yang berkaitan dengan jabatan yang dibutuhkan oleh organisasi. Pengujian atau tes ini dapat berupa pengujian kompetensi, pengujian keterampilan teknikal, pengujian ilmu pengetahuan, dan pengujian kepribadian.

3) Wawancara ketenagakerjaan (employment interview). Wawancara kerja merupakan pertukaran informasi antara pewawancara dengan pelamar yang berpotensi untuk diangkat sebagai karyawan. Wawancara ini umumnya berwujud percakapan formal yang diselenggarakan untuk mengetahui apakah calon karyawan yang diwawancarai tersebut telah sesuai dalam mengisi posisi yang dibutuhkan. Sesi Interview dapat dilakukan secara one to one (antara pewawancara dan calon karyawan), panel interview (antara komite penyeleksi dengan calon karyawan) atau group interview (antara pewawancara dengan beberapa orang calon karyawan). 
4) Pengecekan latar belakang dan referensi. Pengecekan latar belakang dan pemeriksaan referensi adalah suatu alur untuk melakukan verifikasi terhadap informasi yang diberikan oleh pelamar. Perusahaan akan menghubungi atau mengirimkan surat resmi teman dekat, kerabat dan keluarga, atau perusahaan terdahulu dari pelamar. Pengecekan dan pemeriksaan tersebut dilakukan perusahaan untuk memastikan informasi yang diberikan oleh pelamar tersebut adalah sesuai dan benar adanya.

5) Evaluasi medis. Setelah melewati beberapa proses seleksi, mekanisme selanjutnya ialah evaluasi medis / cek kesehatan terhadap pelamar yang paling berkapasitas untuk diangkat sebagai karyawan. Meski evaluasi medis memiliki biaya yang cukup tinggi, perusahaan tetap mengadakan evaluasi medis dengan tujuan untuk memastikan bahwa pelamar memiliki kesehatan fisik yang baik sehingga menurunkan absensi, memangkas biaya pengobatan dan biaya asuransi jiwa, ataupun agar mendapatkan SDM yang memenuhi persyaratan kesehatan fisik untuk sebuah pekerjaan tertentu. 
6) Keputusan penyeleksian (selection decision). Sesudah mendapatkan seluruh informasi yang dibutuhkan dan melengkaoi semua persyaratan yang ditentukan, langkah yang paling krusial dalam proses rekrutmen adalah keputusan pemilihan. Keputusan pemilihan disimpulkan berdasarkan perolehan dari wawancara tahap awal, pengujian seleksi, wawancara kerja, pengecekan latar belakang dan penyelidikan referensi, serta evaluasi kesehatan. Di proses inilah perusahaan akan menetapkan apakah pelamar tersebut layak diterima sebagai karyawan atau tidak.

7) Surat pengangkatan (appointment letter). Langkah penutup dalam tahap rekrutmen SDM adalah mengangkat pelamar yang telah terpilih menjadi karyawan dengan mencetak surat pengangkatan.

\section{J. Orientasi dan Penempatan Karyawan}

Orientasi adalah upaya pendidikan dan pelatihan awal bagi para karyawan baru yang memberikan mereka gambaran mengenai perusahaan, jabatan, dan kelompok kerja. Orientasi terdiri dari 2 model, yaitu: 
a) Induksi: yakni pada tahap awal, karyawan baru mempelajari mengenai hal yang berkaitan dengan perusahaan dan sistem tata kelolanya. Hal-hal yang umum dijelaskan adalah sejarah perusahaan, bidang usaha perusahaan, struktur organisasi perusahaan, kesejahteraan karyawan, peraturan-peraturan dalam perusahaan, hak dan kewajiban karyawan, peraturan promosi, dan karyawan lama beserta kedudukannya dalam perusahaan. Induksi dapat dilakukan manajer SDM atau atasan langsung / penyelia karyawan bersangkutan.

b) Sosialisasi: yaitu proses induksi yang berjangka lebih panjang dimana karyawan baru mendalami normanorma, budaya, sistem nilai, dan pola perilaku yang diisyaratkan oleh departemen perusahaan atau organisasi.

Tujuan diadakan orientasi bagi karyawan baru diantaranya adalah:

1) Pengenalan prosedur pekerjaan.

2) Merekatkan hubungan dengan perusahaan. 
3) Memberikan karyawan baru perasaan memiliki dengan menunjukan bagaimana pekerjaan mereka selaras dengan keseluruhan perusahaan.

4) Mengurangi rasa gelisah dan stres yang dialami oleh karyawan baru.

5) Menekan biaya start-up.

6) menginformasikan peran mereka masing-masing.

7) Memberitahukan mengenai organisasi dan kebijakannya.

8) Mengenalkan karyawan baru dengan rekan-rekan kerja mereka.

Penempatan karyawan adalah penugasan (assignment) atau penugasan kembali (reassignment) seorang individu pada jabatan baru. Tujuan penempatan karyawan ialah untuk menugaskan orang yang tepat pada jabatan yang sesuai dengan minat dan kemampuanya, sehingga SDM yang tersedia menjadi lebih produktif.

Terdapat dua jenis penempatan yaitu:

1) Penempatan secara vertikal: (1) Promosi, yaitu Karyawan dipindahkan ke posisi lain yang lebih tinggi, baik dari segi bayaran, tanggung jawab, dan/atau level 
organisasionalnya. (2) Demosi, Karyawan dipindahkan ke posisi lain yang lebih rendah, baik dari segi bayaran, tanggung jawab, dan/atau level organisasionalnya.

2) Penempatan secara horizontal: (1) Job rotation, karyawan dipindahkan secara permanen atau dalam jangka waktu tertentu ke posisi lain yang setara, baik dari segi bayaran, tanggung jawab, dan/atau level organisasionalnya. (2) Job enrichment, memperkaya rancangan tugas untuk memberikan kepuasan kerja dengan cara melibatkan pekerja lebih jauh dengan perencanaan, penyelenggaraan, pengambilan keputusan, dan pengawasan pekerjaan. (3) Job enlargement, sebuah teknik penempatan di mana jumlah tugas yang berhubungan dengan pekerjaan semakin melebar untuk menambah variasi yang lebih besar dalam pekerjaan, sehingga mengurangi kemonotonan dalam bekerja.

Pemberian informasi mengenai penempatan pada karyawan baru akan menambah wawasan mereka pada perusahaan dan mengurangi tingkat kecemasan mereka terhadap pekerjaan barunya. Terdapat beberapa faktor yang mempengaruhi penempatan kerja dalam perusahaan: 
a) Perkembangan Perusahaan.

Perkembangan bisnis memicu terjadinya pengisian jabatan pekerjaan baru, baik melalui promosi internal maupun promosi eksternal.

b) Reorganisasi.

Reorganisasi dari perusahaan akan menimbulkan jenis yang beragam dalam hal kegiatan - kegiatan manajemen SDM, misalnya jika terjadi merger, akuisisi, restrukturisasi perusahaan. Aktifitas reorganisasi akan mempengaruhi aktivitas departemen SDM, seperti rancangan pekerjaan, kompensasi, manfaat, hubungan pekerja, dan program pensiun dini. Hal ini akan mempengaruhi keputusan penempatan karyawan.

c) Keadaan Perekonomian.

Imbas dari menurunnya pertumbuhan ekonomi adalah secara signifikan akan menyusutkan ketersediaan pekerjaan, baik bagi para karyawan yang permanen, temporer, serta sekaligus bagi pencari kerja. Sebaliknya, jika kondisi ekonomi menanjak, maka departemen SDM akan proaktif dalam melaksanakan kegiatannya, seperti pemeliharaan dan 
promosi untuk karyawan yang ada, serta rekrutmen dan seleksi untuk karyawan yang baru.

d) Atrisi.

Atrisi merupakan perampingan jumlah karyawan yang disebabkan terjadinya terminasi, pengunduran diri, pengalihan keluar dari unit bisnis, dan meninggal.

\section{K. Soal Soal}

1. Mengapa analisis pekerjaan menjadi bagian yang sangat vital bagi kesuksesan pengadaan SDM?

2. Jelaskan tujuan tujuan dari penyelenggaraan evaluasi pekerjaan!

3. Jelaskan keuntungan dari penyederhanaan pekerjaan!

4. Terangkan tujuan tujuan dari perencanaan tenaga kerja!

5. Apakah perbedaan dari perekrutan metode ilmiah dan non ilmiah?

6. Bagaimanakah Manajemen SDM mengetahui kebenaran informasi yang diberikan oleh pelamar? Jelaskan!

7. Mengapa program induksi harus dilakukan ke karyawan baru perusahaan? Jelaskan!

8. Jelaskan definisi dan perbedaan penempatan secara vertikal dan horizontal! 


\section{Pengembangan}

Karyawan

\section{A. Pentingnya Pengembangan Karyawan}

Pengembangan sumber daya manusia dapat dimaknakan sebagai seperangkat kegiatan yang terarah dan sistematis, dirancang untuk menyediakan para karyawannya dengan kemampuan dan keterampilan yang dibutuhkan dalam menyelesaikan pekerjaannya secara efektif dan efisien, baik pada saat ini maupun di masa mendatang.

Pengembangan sumber daya manusia dalam sebuah organisasi perlu dilakukan secara terencana dan berkesinambungan. Progam pengembangan SDM idealnya disusun secara cermat dan berdasarkan metode-metode ilmiah serta berpatokan pada keterampilan yang dibutuhkan organisasi saat ini maupun masa depan. Pengembangan SDM haruslah bertujuan untuk meningkatkan kemampuan teknis, teoritis, konseptual serta moril karyawan supaya prestasi dan performa kerjanya baik dan mencapai hasil yang maksimal. 
Seiring berkembangnya zaman, pengembangan SDM dirasa semakin penting faedahnya karena tuntutan jabatan, kemajuan teknologi, dan semakin ketatnya persaingan diantara perusahaan yang sejenis. Setiap sumber daya manusia yang ada di dalam sebuah perusahaan dituntut agar bekerja secara efektif dan efisien, sehingga daya saing perusahaan semakin besar. Pengembangan SDM dilakukan baik untuk tujuan nonkarier maupun karier bagi sumber daya manusia melalui pelatihan atau pendidikan.

\section{B. Tujuan dan Manfaat Pengembangan SDM}

Dalam arti luas, tujuan dari pengembangan SDM adalah untuk memastikan bahwa perusahaan mempunyai individu yang berkualitas untuk mencapai tujuan organisasi baik dalam jangka pendek maupun jangka panjang. Tujuan tersebut bisa dicapai dengan memastikan bahwa setiap individu yang tersedia dalam organisasi memiliki pengetahuan, keterampilan, dan keahlian dalam memenuhi tingkat kemampuan yang disyaratkan dalam melaksanakan pekerjaaan secara efektif dan efisien.

Dalam arti spesifik, pengembangan SDM memiliki tujuan: 
1) Meningkatkan produktivitas kerja. Dengan pengembangan; technical skill, human skill, dan managerial skill karyawan akan meningkat sehingga produktivitas dan prestasi kerjanya semakin tinggi.

2) Mencapai efisiensi. Pengembangan SDM bermaksud dalam meningkatkan efisiensi (tenaga, waktu, bahan baku, mengurangi ausnya mesin-mesin, dll) agar pemborosan berkurang. Berkurangnya pemborosan akan memangkas biaya produksi sehingga daya saing perusahaan semakin tinggi.

3) Meminimalisir kerusakan. Pengembangan SDM memiliki intensi untuk mengurangi kerusakan barang, produk, dan mesin karena karyawan kian ahli dan terampil dalam pelaksanaan pekerjaannya.

4) Mengurangi kecelakaan. Pengembangan bertujuan untuk mengurangi tingkat kecelakaan karyawan, sehingga jumlah beban pengobatan perusahaan dapat ditekan.

5) Meningkatkan pelayanan. Pengembangan dimaksudkan agar pelayanan SDM kepada nasabah perusahaan menjadi semakin baik, karena pemberian 
pelayanan yang baik merupakan daya tarik yang sangat penting bagi konsumen dan partner perusahaan.

6) Memelihara moril pegawai. Dengan pengembangan, moril SDM akan lebih baik karena keahlian dan keterampilannya menjadi lebih sesuai dengan pekerjaannya sehingga mereka semakin antusias dalam menyelesaikan pekerjaanya dengan hasil yang baik.

7) Meningkatkan peluang karier. Dengan pengembangan, kesempatan karyawan dalam peningkatan kariernya akan semakin terbuka lebar karena keahlian, keterampilan, dan prestasi kerjanya menjadi lebih baik.

8) Meningkatkan kemampuan konseptual. Melalui pengembangan, SDM bertambah cakap dan semakin cepat dalam mengambil keputusan yang lebih baik karena technical skill, human skill, dan managerial skill nya lebih baik.

9) Meningkatkan kepemimpinan. Melalui pengembangan, kepemimpinan seorang manajer akan lebih baik, komunikasinya lebih cakap, motivasinya lebih tertata sehingga pembinaan kerjasama vertikal dan horizontal semakin sinergis. 
10) Peningkatan kompensasi. Dengan pengembangan, kompensasi (gaji, insentif, dan tunjangan) SDM akan meningkat karena prestasi kerja mereka semakin tinggi.

\section{Pelatih pengembangan SDM}

Pelatih atau instruktur yaitu individu / tim yang memberikan pelatihan atau pendidikan terhadap para karyawan. Pelatih memegang peranan penting terhadap perkembangan kemampuan para karyawan peserta pengembangan. Pelatih yang akan merealisasikan pengembangan adalah pelatih internal, pelatih eksternal, serta gabungan internal dan eksternal.

1) Pelatih internal.

Pelatih internal adalah individu atau tim pelatih yang ditugaskan oleh perusahaan untuk memberikan pelatihan atau pendidikan kepada karyawan. Setiap manajer / kepala divisi mutlak menjadi pelatih internal bagi bawahannya dengan menginstruksikan petunjuk dan pedoman penyelesaian pekerjaan, cara pengoperasian peralatan, mesin, dan yang lainnya. Pelatih internal hanya mendidik karyawan dalam lingkungan perusahaan tersebut saja. 
2) Pelatih eksternal

Pelatih eksternal adalah individu atau suatu tim pelatih dari luar organisasi yang diminta untuk mengisi materi pengembangan kepada karyawan di sebuah perusahaan. Umumnya, karyawan akan ditugaskan untuk mengikuti lembaga - lembaga pendidikan atau pelatihan.

3) Gabungan internal dan eksternal

Pelatih gabungan internal dan eksternal adalah suatu tim himpunan dari pelatih internal dan eksternal yang memberikan pengembangan kepada para karyawan. Cara ini dinilai paling baik digunakan karena pengembangan yang ditangani tim internal dan eksternal akan akan saling isi mengisi dalam memberikan materi pengembangan, baik teoritis maupun praktis, kepada SDM sebuah perusahaan.

\section{Jenis dan Teknik Dalam Pengembangan Karyawan}

Jenis pengembangan SDM jika dilihat berdasarkan lama waktu pelaksanaannya dibagi menjadi 2 bentuk:

a) Pelatihan. Umumnya pelatihan diadakan hanya pada hitungan harian atau mingguan. Orientasi 
dari pelatihan adalah peningkatan kemampuan karyawan bagi kepentingan jabatannya saat ini.

b) Pendidikan. Lazimnya pendidikan diselenggarakan dalam hitungan bulanan atau bahkan lebih dari satu tahun. Sasarannya adalah peningkatan kinerja karyawan dalam jangka panjang. Keterkaitan dengan karier sangat tinggi karena dengan pendidikan, SDM dipersiapkan oleh organisasi untuk menduduki jabatan yang lebih strategis lagi di masa depan.

Sedangkan jika dilihat dari perspektif output yang ingin dihasilkan, terdapat 4 jenis dari pengembangan:

a) Pengembangan keahlian, atau bisa disebut skils development, merupakan pengembangan yang sering di jumpai dalam organisasi. Tujuan dari pelaksanaan program pengembangannya relatif sederhana: kebutuhan atau kekurangan karyawan diidentifikasi melalui penilaian evaluasi pekerjaan karyawan sehingga karyawan dapat bekerja lebih baik lagi di periode ke depan. 
b) Pengembangan ulang, atau dapat disebut redevelopment, adalah masih merupakan bagian dari pelatihan keahlian. Redevelopment berusaha untuk memberikan kepada SDM tentang keahlian-keahlian yang mereka butuhkan untuk menghadapi tuntutan kerja yang berubah menyesuaikan perkembangan jaman. Seperti tenaga kerja institusi pendidikan yang biasanya bekerja rnenggunakan mesin ketik harus dilatih dengan mesin komputer atau akses internet agar dapat bekerja lebih efektif lagi.

c) Pengembangan lintas fungsional, atau cross fungtional development melibatkan pelatihan atau pendidikan seorang karyawan untuk melakukan aktivitas kerja dalam bidang lain pada organisasi selain dari pekerjaan utama yang ditugaskan untuk karyawan tersebut.

d) Pengembangan tim, atau teamwork development merupakan pengembangan skill komunikasi dan kerjasama yang terdiri dari sekelompok individual untuk menyelesaikan pekerjaan demi tujuan bersama dalam sebuah tim kerja. 
e) Pengembangan kreatifitas, atau creativity development berasaskan pada pengertian hahwa kreativitas dapat dipelajari dan dilatih. Maksud dari creativity development adalah tenaga kerja diajarkan dan diberikan peluang untuk berpikir secara out of the box sehingga mereka dapat mengeluarkan gagasannya yang berdasar pada penilaian rasional sebebas mungkin. Melalui pengembangan ini, karyawan dapat menemukancara atau gagasan baru yang berguna untuk kemajuan organisasi.

Metode pengembangan SDM pada organisasi dapat dibagi menjadi 2 cara:

a. Secara informal: Pengembangan informal adalah pengembangan yang diselenggarakan untuk melengkapi pelatihan formal. Salah satu jenis pelatihan informal disebut Built In training (BIT ) atau pelatihan melekat adalah pengembangan yang berkesinambungan dengan pemberian assignment oleh atasan, untuk mengasah 
kemampuan SDM dalam pelaksanaan tugasnya sesuai dengan standar job analysis.

b. Secara formal: adalah pengembangan yang dilakukan secara resmi oleh perusahaan untuk para karyawan. Pengembangan jenis ini biasanya dilakukan secara terjadwal dan teratur dengan mengacu pada kurikulum yang telah direncanakan. Kurikulum diciptakan berbasis kebutuhan pengembangan yang sudah ditelaah sebelumnya, sehingga materi pengembangan benar-benar berkaitan dan mampu meningkatkan kemampuan pelaksanaan pekerjaan harian karyawan.

Program-program pengembangan dirancang untuk meningkatkan prestasi kerja karyawan, mengurangi tindakan indisipliner dan turnover, serta memperbaiki kepuasan kerja. Ada dua kategori pokok dari teknik pengembangan SDM:

a) On the job training, adalah suatu mekanisme pengembangan yang terorganisasi untuk meningkatkan keterampilan, pengetahuan, kebiasaan kerja dan sikap karyawan. On the job training 
umumnya dilakukan di tempat kerja dan bertujuan untuk memberikan pengetahuan / keterampilan berupa pengalaman kerja (praktik langsung). On the job training dilaksanakan pada setiap karyawan baru, atau karyawan lama yang pindah ke bagian lain. Metode ini biasanya dilakukan secara perorangan.

b) Off the job training, atau pengembangan di luar kerja adalah pengembangan yang berlangsung pada waktu karyawan yang dilatih tidak melaksanakan pekerjaan rutin. Off the job training lazimnya dilaksanakan pada suatu ruangan di luar tempat kerja / dilakukan pada lokasi terpisah dengan tempat kerja dan bertujuan agar SDM menguasai pengetahuan / keterampilan berupa konsep (teori). Off the job training hanya diberikan pada karyawan tetap dan metode ini dilakukan secara berkelompok.

\section{E. Perencanaan Karir Individu}

Perencanaan karier (career planning) terdiri dari dua suku kata, yaitu perencanaan dan karir. Perencanaan diartikan sebagai alur penentuan rencana atau aktifitas yang akan dilakukan pada masa mendatang. Sedangkan karier adalah seluruh pekerjaan yang dilakukan individu selama kehidupan 
kerjanya yang memberikan keteraturan, kelangsungan, dan nilai bagi perjalanan hidup seseorang.

Perencanaan karir individu adalah suatu proses yang digunakan individu untuk memilih tujuan karier dan jenjang karier dan mengisinya secara sistematis. Melalui perencanaan karir individu, setiap karyawan akan mengevaluasi kemampuan dan minatnya sendiri, menimbang kesempatan karir alternatif, menyusun tujuan karirnya kedepan, dan merencanakan aktivitas-aktivitas pengembangan kemampuan dan keahlian untuk mencapai jenjang karir yang diinginkan tersebut.

Tujuan dari perencanaan karir individu antara lain:

1) Memperoleh kesadaran dan pemahaman diri. Hasil perencanaan karir memungkinkan seorang karyawan untuk realistis dalam pengevaluasian dan pemahaman mengenai diri pribadi sehingga mampu membantu pencapaian karir secara tepat, sesuai dengan minat dan bakat. Pengetahuan dalam perencanaan karir dapat menghindari ketidakbahagiaan, kekecewaan, dan ketidakpuasan melalui kesadaran diri yang cermat. 
2) Mencapai kepuasan pribadi. Meraih kepuasan karir secara pribadi adalah salah satu kegunaan perencanaan karir. Individu menunaikan sebagian besar waktunya dengan bekerja, maka individu akan lebih memilih karir yang memberikan keuntungan tertinggi dalam pencapaian kepuasan pribadi. Individu mungkin lebih suka menjalani kegiatan karir yang mirip dengan minat individu, atau yang lebih memberikan perasaan emosional yang menyenangkan, atau yang kian memberikan kebahagiaan fisik.

3) Mempersiapkan diri untuk memperoleh penempatan dan penghasilan yang sesuai. Dalam perencanaan karir, karyawan mungkin ingin menghindari posisi / jabatan yang memberikan peluang terbatas atau tidak sesuai dengan minatnya dan hanya berfokus pada karir yang paling sesuai bagi karyawan tersebut. Pendekatan ini akan membantu karyawan dalam menemukan karir yang diminati dan alternatifnya sehingga karyawan tersebut akan lebih siap dalam menerima persyaratan keahlian, kewajiban yang harus dilaksanakan, dan hak yang akan diterima pada pilihan karir karyawan tersebut. 
4) Efisiensi usaha dan penggunaan waktu. Tujuan lain dari perencanaan karir ialah untuk memungkinkan karyawan memilih karir secara sistematis. Perencanaan secara sistematis akan menolong karyawan dalam menghindari metode coba-coba (trial-and-error) dan membantu menghabiskan lebih banyak waktu bekerja ke arah tujuan lain yang lebih produktif.

\section{F. Manajemen Karir Organisasi}

Manajemen karir adalah mekanisme dimana perusahaan mencoba untuk menyesuaikan minat karir karyawan individual dengan kemampuan perusahaan dalam merekrut dan menempatkan karyawan. Dalam praktiknya, manajemen karir organisasional mencakup berbagai kebijakan dan tindakan organisasi untuk meningkatkan efektivitas karir dari pekerjaannya. Lebih spesifik lagi, aplikasi dari manajemen karir organisasi meliputi program: (1) pemberian konseling untuk membantu karyawan merencanakan karirnya, (2) melacak pekerjaan, keahlian, dan pengalaman relevan lainnya dari karyawan agar perusahaan mampu mengakomodasi tujuan karir karyawan, dan (3) menawarkan workshop untuk 
menambah keahlian dan keterampilan karyawan sehingga dapat membantu karyawan mencapai rencana karinya.

Organisasi memiliki tujuan dan rencana yang harus diraih. Untuk meraih tujuan tersebut diperlukan sumber daya manusia yang qualified (disamping sumber daya lain). Di sisi lain, karyawan juga memiliki rencana dan tujuan karir yang ingin dicapainya. Untuk itu diperlukan sebuah sistem pengembangan karir yang menguntungkan kedua belah pihak.

\section{G. Penilaian Kinerja Karyawan}

Penilaian kinerja adalah evaluasi atas prestasi kerja / performa kerja karyawan dalam rangka menentukan sejauh mana karyawan melakukan pekerjaan secara efektif dan efisien. Esensinya, tujuan penilaian kinerja digunakan untuk:

1. Perbaikan prestasi kerja. Umpan balik pelaksaanaan kerja memungkinkan karyawan, manejer dan departemen personalia dapat membetulkan kegiatan kegiatan mereka untuk memperbaiki prestasi.

2. Penyesuaian kompensasi. Evaluasi prestasi kerja membantu organisasi dalam pengambilan keputusan mengenai besar kecilnya kompensasi yang diterima oleh karyawan. 
3. Keputusan -keputusan penempatan. Promosi dan demosi biasanya dilaksanakan berdasarkan hasil dari penilaian kinerja

4. Kebutuhan pengembangan. Prestasi kerja yang rendah memungkinkan pengadaan pengembangan. Demikian juga, prestasi yang baik mungkin melambangkan potensi yang harus dikembangkan.

5. Pengembangaan karier. Umpan balik prestasi menunjukan keputusan - keputusan karier, yaitu tentang jalur karier tertentu yang harus diambil.

6. Penyimpangan dalam proses rekrutmen dan penempatan. Prestasi yang baik atau jelek menggambarkan kekuatan atau kelemahan prosedur rekrutmen dan penempatan personel manajemen SDM.

7. Ketidakakuratan Informasi. Kinerja yang buruk mungkin menunjukan kesalahan dalam informasi analisa jabatan, perencanaan sumberdaya manusia, atau komponen lain dari sistem informasi SDM organisasi.

8. Kesempatan kerja yang adil. Keputusan penempatan karyawan internal yang diambil tanpa diskriminasi akan meningkatkan moril karyawan untuk bekerja lebih baik lagi. 
9. Tantangan -tantangan Eksternal. Terkadang prestasi kerja dapat dipengaruhi oleh faktor eksternal organisasi seperti keluarga, lingkungan sosial, dll.

\section{H. Mutasi Karyawan}

Mutasi adalah sebuah perubahan posisi / jabatan / tempat / pekerjaan yang dilakukan baik secara horisontal maupun vertikal di dalam satu perusahaan. Esensinya, mutasi termasuk dalam tujuan pengembangan karyawan, karena fungsinya adalah untuk meningkatkan efektivitas dan efisiensi kerja karyawan di dalam perusahaan tersebut.

Salah satu tindak lanjut yang dilaksanakan dari hasil penilaian kinerja / prestasi karyawan adalah mutasi. Karena dengan penilaian kinerja / prestasi karyawan, akan diketahui kemampuan karyawan dalam menuntaskan uraian pekerjaan (job description) yang dibebankan kepada dirinya. Pelaksanaan mutasi harus berbasis pada indeks prestasi yang dapat dicapai oleh karyawan bersangkutan. Dengan diadakannnya mutasi, diharapkan organisasi dapat memberikan uraian pekerjaan, sifat pekerjaan, lingkungan pekerjaan, dan alat-alat kerja yang sesuai bagi karyawan 
perusahaan sehingga ia dapat bekerja secara efektif dan efisien pada posisi / jabatan tersebut.

Mutasi secara vertikal terdapat dua jenis, promosi dan demosi. Promosi adalah penghargaan dengan kenaikan jabatan dalam suatu organisasi. Dengan tersedianya promosi, karyawan akan merasa diperhatikan, dihargai, dan diakui capaian kerjanya oleh organisasi sehingga mereka akan lebih bersemangat dalam memberikan prestasi yang terbaik dan sekaligus juga akan memupuk loyalitas karyawan terhadap organisasi. Pada sisi lain, demosi adalah penurunan posisi / jabatan dalam suatu organisasi dikarenakan berbagai hal, misal adalah tindakan indisipliner dalam bekerja. Demosi atau turun jabatan lumrah dilakukan oleh beberapa organisasi demi peningkatan kualitas kerja, dan juga sebagai motivasi bagi karyawannya agar semakin terpacu dalam meningkatkan kedisiplinannya.

Mutasi secara horizontal merupakan pemindahan karyawan dari satu jabatan atau tempat ke pekerjaan yang lain yang setara tanpa diikuti dengan kenaikan atau penurunan jabatan. Jenis mutasi horizontal adalah job rotation, job enlargement, dan job enrichment. Disebutkan bahwa manfaat dari mutasi horizontal adalah: 
1. Untuk melengkapi kebutuhan SDM di unit kerja lain.

2. Untuk mengeliminasi rasa bosan dan jenuh individu dalam pekerjaannya.

3. Untuk memberikan motivasi kepada individu dalam mengembangkan kemampuan dan keterampilannya.

4. Untuk menyanggupi kebutuhan karir karyawan yang disesuaikan dengan minat, keahlian, dan kemampuannya.

\section{Hasil Evaluasi Pengembangan SDM}

Evaluasi pengembangan merupakan suatu mekanisme untuk mengumpulkan data dan informasi yang diperlukan dalam program pengembangan. Evaluasi pengembangan lebih berfokus pada tinjauan ulang proses pengembangan, penilaian hasil pengembangan, dan dampak yang ditimbulkan dari pengembangan. Evaluasi pengembangan memiliki fungsi sebagai pengendali dari hasil program pengembangan sehingga menjamin pelaksanaan program pengembangan dapat terlaksana secara sistematis, efektif dan efisien. Evaluasi pengembangan mencoba menggali informasi mengenai perwujudan program pengembangan, juga 
memasukkan umpan balik dari peserta pengembangan yang sangat berkontribusi dalam perbaikan kualitas pengembangan tersebut.

Terdapat dua model evaluasi dalam pengembangan SDM:

1. Model evaluasi summative, yaitu model yang hanya membandingkan antara tujuan yang ingin dicapai dan hasil yang tercapai, apakah suatu program berhasil atau tidak, tanpa memperhatikan proses yang terjadi.

2. Model evaluasi formatif, adalah model evaluasi yang ditujukan terhadap proses yang terjadi, dengan tujuan untuk memberikan umpan balik bagi pelaksana program pengembangan. Evaluasi formatif secara hakikat merupakan penilaian yang dilaksanakan ketika program pengembangan masih berlangsung. Tujuannya adalah melihat seberapa jauh program pengembangan yang dirancang dapat berjalan, sekaligus mengidentifikasi kendala yang terjadi. Dengan diketahuinya kendala dan hambatan sehingga program pengembangan berjalan tidak lancar, penanggungjawab program pengembangan dapat 
mengadakan perbaikan yang menyokong kelancaran pencapaian tujuan dari program pengembangan.

\section{J. Fungsi Umpan Balik}

Secara profesional, instruktur pengembangan bertanggung jawab atas keberhasilan para peserta pengembangan menuju tujuan yang diinginkan oleh perusahaan. Tidak terdapat seorangpun instruktur menginginkan peserta pengembangan gagal dalam meraih prestasi. Kegagalan belajar peserta pengembangan bukan cuma kerugian bagi yang peserta bersangkutan, tetapi juga kerugian bagi instruktur dan perusahaan. Berbekal ilmu, instruktur berupaya agar tidak ada seorang peserta didik yang mengalami kegagalan dalam pengembangan keterampilan dan kemampuannya. Salah satunya dengan cara memberikan umpan balik dalam proses pengembangan.

Umpan balik ialah komentar instruktur terhadap hasil latihan dan belajar peserta pengembangan. Komentar ini dapat dilakukan secara tertulis atau secara lisan, secara langsung maupun tidak lansung kepada perserta yang bersangkutan. Selain dari instruktur, umpan balik dapat juga 
diperoleh peserta dari rekannya yang lain. Pada hakikatnya, dengan adanya umpan balik diharapkan:

1. Peserta pengemabangan termotivasi untuk lebih giat berlatih belajar karena pekerjaannya dihargai.

2. Setelah peserta mendapat saran atau penilaian, para peserta akan lebih memahami kekurangan pada pekerjaannya dan lebih termotivasi untuk memperbaikinya.

3. Intstruktur dapat segera melihat kekurangan perencanaan program pengembangannya dan dapat berusaha meningkatkan kompetensinya.

\section{K. Pemberian Umpan Balik}

Umpan balik (feedback) adalah tanggapan yang diberikan oleh seorang komunikan (penerima pesan) ketika seorang komunikator (pemberi pesan) sedang menyampaikan pesannya. Dalam program pengembangan, instruktur dapat memberikan feedback ke peserta pada saat:

a. Di lembar evaluasi

Lembar evaluasi (dapat berupa tes tulis atau observasi kegiatan, yang diadakan secara terencana atau 
mendadak) dapat dijadikan kesempatan untuk memberikan umpan balik terhadap peserta pengembangan, instruktur pengembangan, dan perusahaan.

b. Di dalam kelas

Disaat proses pelatihan dan pendidikan berlangsung, instruktur hendaknya mengamati kegiatan peserta. feedback dapat dilakukan dengan :

1) Ketika peserta mengajukan pertanyaan, instruktur dapat memberikan kesempatan pada peserta lain untuk memberikan tanggapan atau untuk didiskusikan dengan rekan sejawatnya. Komentar akan datang dari berbagai pihak sehingga terjadi interaksi antara instruktur dengan peserta, dan peserta dengan peserta. Dengan dialog dan pertukaran pikiran seperti ini, peserta baik yang bertanya maupun peserta lain akan mendapatkan proses pemecahan masalah dan informasi yang lebih mendalam.

2) Pada saat dialog / pertukaran pikiran berlangsung, instruktur hendaknya melibatkan diri agar dapat 
mengetahui proses berpikir peserta dalam memahami sebuah konsep.

3) Dari kesimpulan sebuah pemecahan masalah, instruktur dapat melihat kekurangan dan kelemahan dari peserta yang terlibat aktif dalam dialog. Kemudian instruktur memberikan komentar dan petunjuk untuk merevisinya sehingga peserta mendapatkan hasil yang terbaik dalam proses pemecahan masalah tersebut.

c. Pada praktik kerja peserta

Praktik kerja peserta yang dilakukan dalam pengembangan merupakan hasil usaha peserta berdasarkan kemampuannya masing-masing. Mereka ingin mengetahui seberapa jauh pekerjaannya dinilai oleh instruktur atau rekan sejawatnya. Dalam hal ini, instruktur hendaknya memberikan pujian kepada pesertayang hasil pekerjaannya baik. Jika hasil pekerjaan peserta kurang sempurna, berikan masukan yang membangun agar peserta makin termotivasi untuk meningkatkan performanya. 


\section{Keterkaitan Prestasi Dengan Kompensasi Stratejik}

Prestasi kerja adalah performa kerja secara kualitas dan kuantitas yang digapai oleh seorang karyawan dalam pelaksanaan tugasnya sesuai dengan tanggung jawab yang dipercayakan kepadanya. Salah satu tujuan pengembangan SDM adalah meningkatkan prestasi kerja pada suatu organisasi. Faktor prestasi kerja merupakan salah satu faktor yang signifikan dalam menentukan kelangsungan hidup suatu perusahaan. Dengan tingkat prestasi kerja yang tinggi, perusahaan pada gilirannya akan memperoleh laba yang tinggi yang dapat digunakan untuk berkembang dan menunjang kegiatan operasionalnya.

Metode kompensasi untuk SDM sangat vital bagi perusahaan dalam membentuk tingkat prestasi kerja karyawan, karena organisasi sebesar apapun tanpa ditunjang oleh individu - individu yang potensial akan sangat sulit untuk berkembang. Dengan adanya metode kompensasi yang adil, konsisten, dan transparan, moril SDM dalam sebuah organisasi akan terangkat dimana akhirnya loyalitas terhadap perusahaan akan menjadi lebih tinggi. Hal tersebut akan 
mengarah pada peningkatan prestasi kerja karyawan di sebuah perusahaan.

Tidak ada yang menyangsikan bahwa uang adalah elemen pokok dalam pemberian motivasi kerja individu. Hal demikian tercermin pada besaran kompensai atau benefit yang diperoleh karyawan. Semakin tinggi nilai kompensasi, semakin tinggi motivasi kerja karyawan. Namun patut diperhatikan bahwa elemen uang tidak selalu sebagai elemen satu-satunya yang dapat memotivasi karyawan untuk bekerja dengan lebih baik. Jika dikaitkan dengan teori motivasi Herzberg contohnya, uang digunakan sebagai pemelihara motivasi yang sudah ada agar tidak mengalami penurunan. Karena itu selain uang, maka organisasi harus mencari bentuk lain dalam memotivasi kerja karyawan misalnya membangun suasana kerja yang nyaman, kepemimpinan yang memotivasi, fasilitas kerja yang baik, dll. Hal lain yang disebutkan barusan itulah yang disebut dengan jenis kompensasi yang sifatnya non-finansial.

\section{Soal Soal}

1. Sebutkan dan jelaskan tujuan dari pengembangan SDM!

2. Menurut pendapat Anda, tipe instruktur apakah yang paling baik untuk pengembangan SDM? Jelaskan! 
3. Jelaskan perbedaan antara pelatihan dan pendidikan!

4. Menurut pendapat Anda, mana jenis pengembangan yang paling baik: Off the job training atau on the job training?

5. Jelaskan kegunaan perencanaan karir individu!

6. Jelaskan kegunaan manajemen karir organisasional!

7. Jelaskan 2 jenis mutasi karyawan!

8. Jelaskan fungsi dari umpan balik!

9. Terangkan bagaimana umpan balik sebaiknya dilakukan!

10. Jelaskan keterkaitan dari prestasi dan kompensasi! 


\section{Kompensasi}

\section{A. Pentingnya Kompensasi}

Ada beberapa factor yang mempengaruhi prestasi kerja dari karyawan tersebut yang salah satunya adalah pemberian kompensasi. Masalah kompensasi merupakan masalah yang tidak sederhana sebab apabila kompensai dapat diberikan secara benar, maka karyawan akan dapat lebih terpuaskan dan termotivasi untuk mencapai sasaran-sasaran organisasi (perusahaan). Sebaliknya apabila kompensasi tidak diberikan secara benar akan berakibat tidak menguntungkan bagi tercapainya sasaran-sasaran perusahaan yang telah direncanakan.

Kompensasi merupakan alat pengikat perusahaan terhadap karyawannya, faktor penarik bagi calon karyawan dan faktor pendorong seseorang menjadi karyawan. Dengan demikian kompensasi mempunyai fungsi yang cukup penting di dalam memperlancar jalannya roda organisasi/ perusahaan. Menurut Martoyo (1994), fungsi kompensasi adalah: 
a. Penggunaan SDM secara lebih efisien dan lebih efektif.

Kompensasi yang tinggi pada seorang karyawan mempunyai implikasi bahwa organisasi memperoleh keuntungan dan manfaat maksimal dari karyawan yang bersangkutan karena besarnya kompensasi sangat ditentukan oleh tinggi/rendahnya produktivitas kerja karyawan yang bersangkutan. Semakin banyak pegawai yang diberi kompensasi yang tinggi berarti semakin banyak karyawannya yang berprestasi tinggi. Banyaknya karyawan yang berprestasi tinggi akan mengurangi pengeluaran biaya untuk kerja-kerja yang tidak perlu (yang diakibatkan oleh kurang efisien dan efektifitasnya kerja). Dengan demikian pemberian kompensasi dapat menjadikan penggunaan SDM secara lebih efisien dan lebih efektif.

b. Mendorong stabilitas dan pertumbuhan ekonomi.

Sistem pemberian kompensasi yang baik secara langsung dapat membantu stabilitas organisasi dan secara tidak langsung ikut andil dalam mendorong stabilitas dan pertumbuhan ekonomi. Sebaliknya 
pemberian kompensasi yang kurang baik dapat menyebabkan gejolak di kalangan karyawan akibat ketidakpuasan. Pada gilirannya gejolak ketidakpuasan ini akan menimbulkan kerawanan ekonomi.

Dengan pemberian kompensasi yang benar dan memadai, perputaran karyawan juga dapat diperkecil dan biaya pendidikan untuk karyawan baru dapat ditekan, sehingga pihak perusahaan dapat diuntungkan.

\section{B. Jenis dan Pembagian Kompensasi}

Menurut Mangkuprawira (2011) kompensasi atau imbalan jasa sebenarnya mempunya arti yang lebih luas dari upah atau gaji. Kompensasi atau imbalan jasa sebenarnya mempunyai arti yang lebih luas dari upah atau gaji. Kompensasi justru mencakup upah atau gaji, tunjangantunjangan baik berupa uang, fasilitas, atau kemudahan dan hak-hak istimewa lainnya seperti tunjangan representasi untuk eksekutif, rumah dinas, cuti khusus, keanggotaan dalam klub khusus dan lain-lain. Menurut Martochio (2013) Pengertian kompensasi adalah balas jasa yang diberikan oleh perusahaan kepada karyawannya yang dapat dinilai dengan uang dan mempunyai kecenderungan diberikan secara tetap, 
sedangkan menurut William B. Werther dan Keith Davis yang disadur oleh Melayu. SP. Hasibuan (1990:134) dikemukakan bahwa :

Kompensasi adalah apa yang seorang pekerja terima sebagai balasan dari pekerjaan yang dilakukannya. Baik upah perjam ataupun gaji periodik yang di desain dan dikelola oleh bagian personalia)

Dari beberapa uraian pendapat di atas jelas bahwa kompensasi mengandung cakupan yang lebih luas daripada sekedar "Pemberian upah dan gaji", namun mencakup balas jasa yang bersifat finansial maupun non finansial yang diberikan oleh perusahaan kepada karyawannya. (Handoko, 2012). Kompensasi finansial terdiri dari:

a. Kompensasi finansial langsung (Direct Financial Compencation), yang terdiri dari bayaran (pay) yang diperoleh karyawan dalam bentuk gaji, upah, bonus, dan kompensasi

b. Kompensasi finansial tidak langsung (Indirect financial Compensation) disebut juga tunjangan yang meliputi imbalan-imbalan finansial yang tidak tercakup dalam kompensasi langsung. 
c. Kompensasi non finansial terdiri dari kepuasan yang diperoleh seseorang dari pekerjaan itu sendiri, dari lingkungan psikologis dan atau fisik dimana orang tersebut bekerja. Tipe kepuasan ini biasanya diperoleh dari keberhasilan melaksanakan tugas yang sangat bermakna.

Sedangkan pengertian lebih lanjut mengenai gaji, upah, tunjangan, komisi dan bonus adalah sebagai berikut :

I. Gaji (Salary), umumnya berlaku untuk tarif bayaran mingguan, bulanan, atau tahunan (Terlepas dari lamanyan jam kerja).

II. Upah (Wage), upah merupakan basis-basis bayaran yang kerap digunakan bagi pekerja-pekerja produksi. Biasanya berhubungan dengan tarif gaji perjam (Semakinlama jam kerjannya, semakin besar bayarannya).

III. Tunjangan (Benefit), pembayaran keuangan tidak langsung yang diberikan kepada karyawan, contohcontoh tunjangan asuransi jiwa dan kesehatan, liburan-liburan yang ditanggung perusahaan, program pension, rencana pendidikan dan tunjangan- 
tunjangan lainnya yang berhubungan dengan kepegawaian.

IV. Komisi (Commission), mengaitkan gaji terhadap penjualan dibandingkan terhadap produksi, individuindividu mungkin mendapatkan presentase tertentu dari penjualan, presentase tertentu dari penjualan baru, atau untuk mencapai kuota penjualan. Beberapa tenaga pemasaran mendapatkan gaji dasar dan setelah itu memperoleh komisi diatas gaji dasar tersebut.

V. Bonus (Bonus), adalah pembayaran secari partai yang dikaitkan denagan kinerja yang luar biasa/ eksesional. Contohnya, seorang eksekutif biro iklan mungkinmendapatkan bonus untuk sebuah kontrak atau klienyang baru. Bonus tidak hanya membantu perusahaan mengendalikan biaya-biaya, namun tampaknya juga memperbaiki kepuasan karyawan. Perusahaan yang memberikan kenaikan gaji kepada seorang karyawan adalah membuat perubahan permanen yang meningkatkan bayarannya sekarang, dimasa yang akan datang, dan juga pada saat pensiun. Hal ini jauh lebih mahal dibandingkan pembayaran 
bonus sekali waktu. Program-program bonus lebih mudah dipertahankan karena tidak memerlukan banyak dokumentasi dan sangat fleksibel.

\section{Sistem dan Kebijaksanaan Kompensasi}

Martochio (2013) menyatakan kompensasi sebagai apa yang diterima pekerja sebagai tukaran atas kontribusinya kepada organisasi. Selanjutnya Martochio juga menyatakan bahwa di dalam kompensasi terdapat sistem insentif yang menghubungkan kompensasi dengan kinerja.

Menurut Wibowo (2016) menyatakan tujuan manajemen kompensasi adalah:

a. Memperoleh personil berkualitas; Kompensasi perlu ditetapkan cukup tinggi untuk menarik pelamar. Tingkat pembayaran harus tanggap terhadap permintaan dan penawaran tenaga kerja di pasar kerja karena harus bersaing untuk mendapatkan tenaga kerja.

b. Mempertahankan karyawan yang ada; Pekerja dapat keluar jika kompensasi tidak kompetitif dibanding perusahaan lain, akibatnya tingkat perputaran tenaga kerja (labour turn over) tinggi. Dengan demikian perlu 
dipertimbangkan mana yang lebih baik dan menguntungkan antara meningkatkan kompensasi dengan mencari pekerja baru dengan konsekuensi harus melatih kembali pekerja baru.

c. Memastikan keadilan; Manajemen kompensasi berusaha keras menjaga keadilan internal dan eksternal. Keadilan internal memerlukan bahwa pembayaran dihubungkan dengan nilai relatif pekerjaan sehingga pekerja mendapatkan pembayaran yang sama. Keadilan eksternal berarti membayar pekerja sebesar apa yang diterima pekerja yang setingkat di perusahaan lain.

d. Menghargai perilaku yang diinginkan; Pembayaran harus memperkuat perilaku yang diinginkan dan bertindak sebagai insentif untuk perilaku di masa depan. Rencana kompensasi yang efektiff menghargai kinerja, loyalitas, keahlian dan tanggung jawab.

e. Mengawasi biaya; Sistem kompensasi yang rasional membantu organisasi memelihara dan mempertahankan pekerja pada biaya yang wajar. Tanpa manajemen kompensasi yang efektif pekerja dapat dibayar terlalu tinggi atau terlalu rendah. 
f. Mematuhi peraturan; Sistem upah dan gaji yang baik mempertimbangkan perraturan pemerintah dan memastikan pemenuhan kebutuhan pekerja.

g. Memfasilitasi saling pengertian; Sistem manajamen kompensasi harus mudah dipahami oleh manajer dan pekerja. Dengan demikian, harus bersifat terbuka sehingga akan terjalin saling pengertian dan menghindari kesalahan persepsi.

Martochio (2015) memberikan gambaran tentang dasar pembentukan dan penyesuaian dari penggajian karyawan dalam organisasi. Misal:

Seorang manajer menerima gaji sebesar Rp.10.000.000,00. Pertanyaan yang timbul adalah: "Mengapa dia dibayar Rp.10.000.000,00?

Bermacam-macam jawaban dapat timbul dari pertanyaan tersebut:

I. Gajinya sesuai dengan berat tugas dan tanggung jawabnya.

II. Gajinya sesuai dengan tingkat pendidikannya.

III. Dia memiliki masa kerja yang lama di perusahaannya. 
IV. Gaji untuk jabatan yang sama di pasaran tenaga kerja berkisar sekitar Rp.10.000.000,00

V. Prestasinya sesuai dengan sesuatu yang dinilai Rp.10.000.000,00

Kalau demikian halnya, pertanyaan yang sangat fundamental adalah: "Apakah yang dijadikan dasar untuk menggaji seseorang?"

Melihat gambaran di atas, tampaknya seseorang digaji dengan sesuatu angka rupiah tertentu yang dapat didasarkan antara lain kepada:

a) Berat ringannya tanggung jawab jabatannya, yang menggambarkan tinggi rendahnya jabatan dalam jenjang manajerial.

b) Tinggi rendahnya tingkat pendidikan.

c) Lamanya masa kerja di perusahaan yang bersangkutan.

d) Tinggi rendahnya nilai jabatan di pasaran tenaga kerja.

e) Keluaran (output) yang dapat dihasilkan oleh sesuatu jabatan.

Untuk dapat menentukan mana yang dapat dijadikan sebagai dasar untuk sistem penggajian bagi suatu perusahaan, 
maka beberapa hal di bawah ini dapat dijadikan sebagai pedoman:

- Sistem penggajian harus dapat menjamin keadilan internal.

- Sistem penggajian harus dapat menampung pengaruh faktor luar, sehingga terjadi keseimbangan.

- Sistem penggajian harus mampu:

1) Menarik tenaga-tenaga baik dari luar.

2) Mempertahankan tenaga-tenaga baik yang ada di dalam.

3) Memotivasi karyawan.

4) Membentuk budaya/iklim perusahaan.

5) Menunjang struktur organisasi.

6) Mencerminkan kemampuan (finansial) perusahaan.

Dalam sistem penggajian modern hendaknya juga diusahakan agar sistem penggajian sederhana dan mudah dimengerti.

Sedagkan menurut Hasibuan (2016), hal yang harus diperhatikan organisasi dalam membuat kebijakan terkait dengan kompensasi di dalam organisasinya adalah: 
1. Bersifat Menarik/ Atraktif.

Sistem penggajian sebaiknya bersifat atraktif, agar menarik bagi orang luar untuk memasuki perusahaan yang memiliki kebijakan tersebut.

2. Bersifat Kompetitif.

Sistem penggajian juga harus bersifat kompetitif agar bisa bersaing dengan perusahaan sejenis atau perusahaan lain yang berada di dalam lingkungannya.

3. Harus dirasakan Adil.

Sistem penggajian harus dapat dirasakan adil bagi semua karyawan, dimana pekerjaan yang memang berat menerima imbalan lebih dibandingkan dengan pekerjaan yang ringan.

4. Bersifat Motivatif.

Sistem penggajian harus bersifat motivatif agar karyawan merasa adanya suatu rangsangan untuk memacu prestasi kerjanya karena adanya nilai imbalan yang sesuai.

Menurut Hasibuan (2011:124), sistem pemberian kompensasi yang umum diterapkan antara lain : 
a. Sistem Waktu.

Dalam sistem waktu besarnya kompensasi (gaji, Upah) ditetapkan berdasarkan standar waktu seperti jam, minggu, bulan. Administrasi penguahan system waktu relative mudah serta dapat diterapkan pada karyawan tetap maupun pekerja harian.

Kebaikan system waktu ialah administrasi pengupahan mudah dan besarnya komponsasi yang akan dibayarkan tetap. Sedangkan kelemahan system waktu ialah pekerja yang malas pun kompensasinya tetap dibayarkan sebesar perjanjian.

b. Sistem Hasil (output)

Dalam system hasil (output) besarnya kompensasi yang dibayarkan selalu didasarkan pada banyaknya hasil yang dikerjakan bukan kepada lamanya waktu mengerjakannya. Sistem hasil ini tidak dapat diterpkan kepada karyawan tetap (system waktu) dan jenis pekerjaan yang tidak mempunyai standar fisik seperti bagi karyawan dan administrasi.

Kebaikan sistem hasil memberikan kesempatan kepada karyawan yang bekerja bersungguh-sungguh serta berprestasi baik akan memperoleh balas jasa 
yang lebih besar. Jadi prinsip keadilan benar-benar diterapkan, pada system hasil yang perlu mendapatkan perhatian sungguh-sungguh adalah kualitas barang yang dihasilkan karena ada kecenderungan dari karyawan untuk mencapai produksi yang lebih besar dan kurang memperhatikan kualitasnya. Manajer juga perlu memperhatikan jangan sampai karyawan memaksakan dirinya untuk bekerja diluar kemampuannya sehingga kurang memperhatikan keselamatannya. Sedangkan untuk kelemahan system hasil ialah kualitas barang yang dihasilkan kurang baik dan karyawan yang kurang mampu balas jasanya kecil, sehingga kurang manusiawi.

c. Sistem Borongan

Sistem borongan adalah suatu cara pengupahan yang menetapkan besarnya jasa didasarkan atas volume pekerjaan dan lama mengerjakannya. Penetapan besarnya balas jasa berdasarkan system borongan cukup rumit lama mengerjakannya, serta banyak alat yang diperlukan untuk menyelesaikannya. 
Jadi dalam system borongan pekerjaan bias mendapat balas jasa besar atau kecil tergantuk atas kecermatan kalkulasi mereka.

\section{Faktor yang Mempengaruhi Besar Kecilnya Kompensasi}

Menurut Mangkuprawira (2011), Dasar dalam menentukan kompensasi ada empat faktor, antara lain: adanya pertimbangan hukum dalam kompensasi, serikat buruh, kebijakan perusahaan, dan prinsip-prinsip keadilan. Faktor-faktor diatas dijabarkan sebagai berikut :

1. Faktor Hukum.

Sejumlah Undang-undang menetapkan apa yang harus dibayar oleh perusahaan pada karywan dari segi upah minimum, tarif lembur dan tunjangan. Jadi setiap perusahaan harus memperhatikan peraturan yang berlaku. Di Indonesia, besaran kompensasi telah diatur dalam UU Ketenagakerjaa Republik Indonesia.

2. Pengaruh serikat pekerja.

Serikat Buruh dan Undang-undang tenaga kerja juga mempengaruhi bagaimana sistem kompensasi 
ditetapkan. Hampir semua negara telah mempunyai perangkat hukum yang melegimitasikan gerakan tenaga kerja untuk berorganisasi, tawar menawar secara kolektif dan bergabung dalam kegiatankegiatan penentuan upah yang wajar bagi mereka, serta saling melindungi sesama buruh. Dengan demikian yang paling baik untuk memperoleh sistem kompensasi diantaranya adalah dengan memperhatikan tuntutan serikat buruh secara umum.

3. Kebijakan kompensasi perusahaan.

Kebijakan kompensasi perusahaan juga mempengaruhi besarnya tarif upah yang dibebankan. Karena kebijakan ini memberikan pedoman yang penting dalam sebuah pekerjaan. Kebijakan ini mencakup basis untuk peningkatan gaji, kebijakan promosi dan demosi, kebijakan pembayaran lembur, dan kebijakan menyangkut pembayaran masa percobaan, cuti dan liburan.

4. Faktor Keadilan.

Kebutuhan akan keadilan adalah faktor penting dalam penentuan tariff kompensasi khususnya keadilan internal dan keadilan eksternal. Secara internal, 
masing-masing karyawan hendaknya memandang kesamaan pembayaran dengan karyawan lain yang ada dalam organisasi. Sedangkan keadilan eksternal, pembayaran harus sebanding dengan tarif dalam organisasi yang lain, hal ini untuk mengantisipasi kesulitan mendapat tenaga kerja.

\section{E. Soal-Soal}

1. Jelaskan menurut pendapat Anda mengenai pentingnya pemberian kompensasi dalam organisasi!

2. Jelaskan jenis jenis kompensasi!

3. Jelaskan sistem pemberian kompensasi!

4. Terangkan secara sederhana mengenai kebijakan kompensasi!

5. Menurut pendapat Anda, faktor apa saja yang mempengaruhi tinggi rendahnya kompensasi dalam sebuah posisi / perusahaan? Jelaskan! 


\section{Pengintegrasian}

\section{Sumber Daya Manusia}

\section{A. Pentingnya Pengintegrasian Karyawan}

Pengintegrasian (integration) adalah fungsi operasional manajemen personalia yang sangat penting, sulit dan kompleks untuk merealisasikannya. Hal ini disebabkan karena karyawan/manusia bersifat dinamis dan mempunyai pikiran, perasaan, harga diri, sifat, serta membawa latar belakang, perilaku, keinginan dan kebutuhan yang berbeda-beda dalam organisasi perusahaan.

Karyawan tidak dapat diperlakukan seenaknya seperti menggunakan faktor-faktor produksi lainnya (mesin, modal atau bahan baku). Karyawan juga harus selalu diikutsertakan dalam setiap kegiatan serta memberikan peran aktif untuk menggunakan alat-alat yang ada. Karena tanpa peran aktif karyawan, alat-alat canggih yang dimiliki tidak ada artinya bagi peruashaan untuk mencapai tujuannya. Tujuan perusahaan hanya dapat dicapai jika para karyawan bergairah bekerja, mengerahkan kemampuannya dalam menyelesaikan 
pekerjaan, serta berkeinginan untuk mencapai prestasi kerja yang optimal.

Jika karyawan kurang berprestasi maka sulit bagi organisasi perusahaan dapat memperoleh hasil yang baik. Hal ini mengharuskan pemimpin menggunakan kewenangannya untuk mengubah sikap dan perilaku karyawan supaya mau bekerja giat serta berkeinginan mencapai hasil yang optimal.

Pengintegrasian adalah kegiatan mensinergikan keinginan karyawan dan kepentingan perusahaan, agar tercipta kerja sama yang memberikan kepuasan. Menurut Hasibuan (2016), usaha untuk pengintegrasian dapat dilakukan melalui: (1) hubungan antar manusia (human relation), (2) motivasi, kepemimpinan, (3) kesepakatan kerja bersama / KKB, dan (4) Collective Bargaining.

Tujuan pengintegrasian adalah memanfaatkan karyawan agar mereka bersedia bekerja keras dan berpartisipasi aktif dalam menunjang tercapainya tujuan perusahaan serta terpenuhinya kebutuhan karyawan. Prinsip pengintegrasian adalah menciptakan kerjasama yang baik dan saling menguntungkan. Pengintegrasian SDM pada sebuah perusahaan adalah hal yang sangat penting dan merupakan 
salah satu kunci untuk mencapai hasil yang baik bagi perusahaan maupun terhadap karyawan sehingga memberikan kepuasan kepada semua pihak. Kayawan dapat memenuhi kebutuhannya dan perusahaan memperoleh laba.

Hubungan antarmanusia (Human Relation) adalah hubungan kemanusiaan yang harmonis, tercipta atas kesadaran dan kesediaan melebur keinginan individu demi terpadunya kepentingan bersama. Tujuannya adalah menghasilkan integrasi yang cukup kukuh, mendorong kerjasama yang produktif dan kreatif untuk mencapai sasaran bersama. Manajer dalam menciptakan hubungan antarmanusia yang harmonis memerlukan kecakapan dan keterampilan tentang komunikasi, psikologi, sosiologi, antropologi dan etologi, sehingga dia memahami serta dapat mengatasi masalah-masalah dalam hubungan kemanusiaan.

\section{B. Hubungan Antar Manusia}

Hubungan antarmanusia (Human Relation) adalah hubungan kemanusiaan yang harmonis, tercipta atas kesadaran dan kesediaan melebur keinginan individu demi terpadunya kepentingan bersama. Tujuannya adalah menghasilkan integrasi yang kokoh, mendorong kerjasama 
yang produktif dan kreatif untuk mencapai sasaran bersama. Manajer dalam menciptakan hubungan antarmanusia yang harmonis memerlukan kecakapan dan keterampilan tentang komunikasi, psikologi, sosiologi, antropologi dan etologi, sehingga dia memahami serta dapat mengatasi masalahmasalah dalam hubungan kemanusiaan.

Manajer dalam membangun hubungan antar manusia (human relation) hendaknya memahami masalah "kepribadian dan perilaku" setiap individu bawahannya.

\section{Kepribadian}

Kepribadian adalah serangkaian ciri yang relatif tetap dan sebagian besar dibentuk oleh faktor keturunan, sosial, kebudayaan, dan lingkungan. Serangkaian variabel ini yang menentukan persamaan dan perbedaan dalam perilaku seseorang individu.

Kekuatan-kekuatan utama yang mempengaruhi kepribadian seseorang adalah kekuatan keturunan, kekuatan kebudayaan, kekuatan hubungan keluarga dan kelas sosial atau pendidikan, dan kekuatan lain dari keanggotaan kelompok. 
Teori Kepribadian

B.1. Teori Sifat (Traitist Theories)

Sifat merupakan bagian yang membentuk kepribadian, petunjuk jalan bagi tindakan dan merupakan sumber keunikan individu. Sifat/ciri cenderung dapat diduga sebagai pengarah perilaku individu berbuat dengan cara yang konsisten dan khas. Kelemahan teori sifat ini belum pasti menunjukkan kepribadian individu yang sama pada setiap situasi, karena perilaku individu masih dipengaruhi oleh lingkungan.

B.2. Teori Psikodinamis (Psychodinamic Theories)

Freud menerangkan perbedaan individual dalam kepribadian dengan mengemukakan bahwa orang menghadapi perangsangnya yang utama secara berbedabeda. Perbedaan kepribadian ini terletak pada Id (bagian ketidaksadaran) dan Superego yang diperlunak oleh Ego. Id adalah sebagai bagian yang primitif dan tidak sadar dari kepribadian, Id bekerja secara tidak rasional, tanpa mempertimbangkan apakah yang diinginkan itu mungkin atau dapat diterima dari segi moral. Superego adalah sikap moral yang dibentuk oleh masyarakat. Secara kasar Superego sesuai 
dengan hati nurani (con-science). Superego sering bertentangan dengan Id. Id ingin mengerjakan apa yang dirasa baik, sedangkan Superego cenderung mengerjakan apa yang benar.

B.3. Teori Humanistis (Humanistic Theories)

Pendekatan humanistis terhadap pemahaman kepribadian memberi tekanan pada perkembangan dan perwujudan diri individu. Teori ini menekankan pentingnya cara mempersepsikan dunia mereka dan kekuatan yang mempengaruhinya.

\section{Pengertian dan Teori Motivasi}

Motivasi berasal dari kata latin movere yang berartin dorongan atau menggerakkan. Motivasi (motivation) dalam manajemen hanya ditujukan pada sumber daya manusia umumnya dan bawahan khususnya. Motivasi mempersoalkan bagaimana caranya mengarahkan daya dan potensi bawahan, agar mau bekerja sama secara produktif berhasil mencapai dan mewujudkan tujuan yang telah ditentukan.

Pentingnya motivasi karena motivasi adalah hal yang menyebabkan, menyalurkan dan mendukung perilaku 
manusia, supaya mau bekerja giat dan antusias mencapai hasil yang optimal. Motivasi semakin penting karena manajer membagikan pekerjaan pada bawahannya untuk dikerjakan dengan baik dan terintegrasi kepada tujuan yang diinginkan.

Perterson dan Plowman mengatakan bahwa orang mau bekerja karena faktor - faktor berikut :

a. The desire to live (keinginan untuk hidup)

b. The desire for position (keinginan untuk suatu posisi)

c. The desire for power (keinginan akan kekuasaan)

d. The desire for recognation (keinginan akan pengakuan)

Motivasi adalah pemberian daya penggerak yang menciptakan kegairahan kerja seseorang agar mereka mau bekerja asma, bekerja efektif dan terintegrasi dengan segala daya upayanya untuk mencapai kepuasan. 


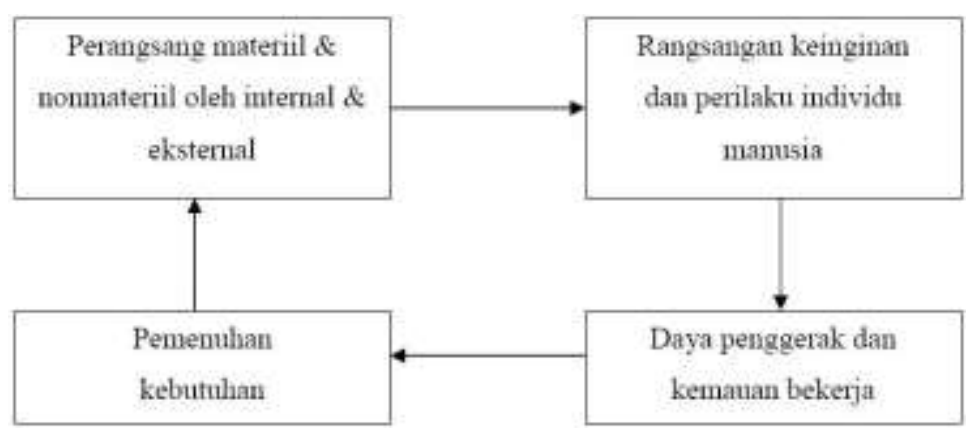

Gambar 5.1 Konsep Motivasi

Keterangan:

1. Perangsang berbentuk materiil atau nonmateriil yang tercipta oleh internal (keinginan) maupun eksternal yang dilakukan oleh manajer.

2. Rangsangan yang menciptakan keinginan (want) dan mempengaruhi perilaku seseorang (individu)

3. Keinginan menjadi daya penggerak dan kemauan bekerja seseorang (individu)

4. Kemauan bekerja menghasilkan pemenuhan kebutuhan dan kepuasan seseorang.

5. Kebutuhan dan kepuasan mendorong menciptakan perangsang selanjutnya dan seterusnya, jadi merupakan siklus.

Tujuan motivasi antara lain sebagai berikut:

a. Meningkatkan moral dan kepuasan kerja karyawan. 
b. Meningkatkan produktivitas kerja karyawan.

C. Mempertahankan kestabilan karyawan perusahaan.

d. Meningkatkan kedisiplinan karyawan.

e. Mengefektifkan pengadaan karyawan.

f. Menciptakan suasana dan hubungan kerja yang baik.

g. Meningkatkan loyalitas, kreativitas dan partisipasi karyawan.

h. Meningkatkan tingkat kesejateraan karyawan.

i. Mempertinggi rasa tanggung jawab karyawan terhadp tugas-tugasnya.

j. Meningkatkan efisiensi penggunaan alat-alat dan bahan baku

Asas-asas dalam teori motivasi:

1) Asas Mengikutsertakan. Maksudnya mengajak bawahan untuk ikut berpartisipasi dan memberikan kesempatan kepada mereka mengajukan ide-ide, rekomendasi dalam proses pengambilan keputusan.

2) Asas Komunikasi. Maksudnya menginformasikan secara jelas tentang tujuan yang ingin dicapai, cara mengerjakannya dan kendala yang dihadapi. 
3) Asas Pengakuan. Maksudnya memberikan penghargaan dan pengakuan yang tepat secara wajar kepada bawahan atas prestasi kerja yang dicapainya.

4) Asas Wewenang yang Didelegasikan. Maksudnya mendelegasikan sebagian wewenang serta kebebasan karyawan untuk mengambil keputusan dan berkreativitas dan melaksanakan tugas-tugas atasan atau manajer.

5) Asas Perhatian Timbal Balik. Asas perhatian timbal balik adalah memotivasi bawahan dengan mengemukakan keinginan atau harapan perusahaan disamping beruasha memenuhi kebutuhankebutuhan yang diharapkan bawahan dari perusahaan.

Terdapat dua jenis metode dalam motivasi

a. Motivasi Langsung (Rirect Motivation)

Adalah motivasi (materiil dan nonmateriil) yang diberikan secara langsung kepada setiap individu karyawan untuk memenuhi kebutuhan serta kepuasannya.

b. Motivasi Tak Langsung (Indirect Motivation) 
Adalah motivasi yang diberikan hanya merupakan fasilitas-fasilitas yang mendukung serta menunjang gairah kerja/kelancaran tugas sehingga para karyawan betah dan bersemangat melakukan pekerjaannya.

\section{Pimpinan dan Teori Kepemimpinan}

Kepemimpinan (leadership) yang ditetapkan oleh seorang manajer dalam organisasi dapat menciptakan integrasi yang serasi dan mendorong gairah kerja karyawan untuk mencapai sasran yang maksimal. Kepemimpinan adalah kata benda dari pemimpin (leader).

Kepemimpinan adalah cara seorang pemimpin mempengaruhi perilaku bawahan, agar mau bekerjasama dan bekerja produktif untuk mencapai tujuan organisasi.

Gaya kepemimpinan menurut Hasibuan (2016), yaitu :

\section{a. Kepemimpinan Otoriter}

Adalah jika kekuasaan atau wewenang, sebagian besar mutlak tetap berada pada pimpinan atau kalau pimpinan itu menganut sistem sentralisasi wewenang. Pengambilan keputusan dan kebijaksanaan hanya ditetapkan sendiri oleh pemimpin, bawahan tidak diikutsertakan untuk 
memberikan saran, ide dan pertimbangan dalam proses pengambilan keputusan. Falsafah pemimpin ialah "bawahan adalah untuk pimpinan/atasan".

Orientasi kepemimpinannya difokuskan hanya untuk peningkatan produktivitas kerja karyawan dengan kurang memperhatikan perasaan dan kesejahteraan bawahan. Pimpinan menganut sistem manajemen tertutup (closed management) kurang menginformasikan keadaan perusahaan pada bawahannya. Pengkaderan kurang mendapat perhatiannya.

\section{b. Kepemimpinan Partisipatif}

Adalah apabila dalam kepemimpinannya dilakukan dengan cara persuasif, menciptakan kerjasama yang serasi, menumbuhkan loyalitas, dan partisipasi para bawahan. Pemimpin memotivasi bawahan agar merasa ikut memiliki perusahaan. Falsafah pemimpin ialah "pimpinan (dia) adalah untuk bawahan".

\section{c. Kepemimpinan Delegatif}

Pada prindipnya pemimpin bersikap, menyerahkan dan mengatakan kepada bawahan "Inilah pekerjaan yang 
harus saudara kerjakan, saya tidak peduli, terserah saudara bagaimana mengerjakannya asal pekerjaan tersebut bisa diselesaikan dengan baik". Disini pimpinan menyerahkan tanggung jawab atas pelaksanaan pekerjaan kepada bawahan dalam arti pimpinan menginginkanagar para bawahan bisa mengendalikan diri mereka sendiri dalam menyelesaikan pekerjaan tersebut. Kematangan pekerjaan dikaitkan dengan kemampuan untuk melakukan sesuatu yang berdasarkan pengetahuan dan keterampilan. Kematangan psikologis dikaitkan dengan kemauan atau motivasi untuk melakukan sesuatu yang erat kaitannya dengan rasa yakin dan keterikatan.

\section{E. Kesepakatan Kerja Bersama dan Collective Bargaining}

Kesepakatan Kerja Bersama (KKB)

Kesepakatan Kerja Bersama (KKB) berperan penting dalam menciptakan pengintegrasian, membina kerja sama dan menghindarkan terjadinya konflik dalam perusahaan. Dengan KKB ini diharapkan permasalahan yang dihadapi karyawan dengan perusahaan dapat diatasi dengan baik. Misalnya : kenaikan gaji/upah, tunjangan hari raya, pemecatan buruh, 
dan lain-lain KKB adalah musyawarah dan mufakat antara pimpinan perusahaan dengan pimpinan serikat karyawan (buruh) dalam memutuskan masalah yang menyangkut

Kebutuhan karyawan dan kepentingan peruashaan. Dengan landasan musyawarah dan mufakafat diharapkan tercipta integrasi yang serasi dalam perusahaan. Kkkaryawan menjadi partner kerja sama yang baik bagi perusahaan.

\section{Collective Bargaining}

Collective bargaining adalah adanya pandangan antara pimpinan perusahaan denga pimpinan serikat buruh (karyawan) dalam menetapkan keputusan-keputusan yang menyangkut kepentingan perusahaan dan kebutuhan buruh. Hal ini dilakukan agar tercipta integrasi yang harmonis dan usaha-usaha untuk menghindari terjadinya konflik dalam perusahaan.

Collective bargaining didasarkan atas perundingan yang berarti adu kekuatan, siapa yang mempunyai posisi kuat maka dialah yang banyak menentukan keputusan. Sedangkan KKB didasarkan atas musyawarah dan mufakat dalam menetapkan keputusan, bukan atas adu kekuatan/posisi. 
Collective bargaining dapat diibaratkan seperti demokrasi barat, sedangkan KKB seperti demokrasi Pancasila.

\section{F. Hubungan pemberian kompensasi individu untuk meningkatkan kepuasan dan integrasi SDM}

Kompensasi merupakan hal yang diterima oleh pegawai, baik berupa uang atau bukan uang sebagai balas jasa yang diberikan bagi upaya pegawai (kontribusi pegawai) yang diberikan untuk organisasi. Pengelolaan kompensasi merupakan kegiatan yang amat penting dalam membuat pegawai cukup puas dalam pekerjaannya. Dengan kompensasi kita bisa memperoleh/menciptakan, memelihara, mempercepat proses integrasi SDM organisasi, dan mempertahankan produktivitas. Tanpa kompensasi yang memadai, pegawai yang ada sekarang cenderung untuk tidak betah dan lebih sering melakukan indisipliner.

Pemberian kompensasi untuk mempercepat proses integrasi SDM organisasi dilakukan saat terdapat perencanaan dalam penempatan karyawan di tempat / posisi yang baru. Penempatan dapat berupa 
Semua proses penempatan diatas umumnya dilakukan melalui kegiatan promosi / penigkatan jabatan, transfer / pengalihan jabatan, demosi / penurunan jabatan, dan pemutusan hubungan kerja sementara atau permanen. Pelaksanaan kegiatan ini sudah barang tentu harus dilakukan dengan baik dalam upaya meningkatkan dukungan sumber daya manusia terhadap organisasi. Pemberian kompensasi yang adil dan sesuai akan dilihat secara positif oleh seluruh karyawan organisasi, sehingga proses pengintegrasian karyawan dalam organisasi dapat berjalan dengan lebih baik lagi.

\section{G. Soal-Soal}

1. Jelaskan manfaat pengintegrasian karyawan dalam organisasi!

2. Jelaskan tujuan dari pemberian motivasi pada SDM organisasi serta terangkan dampaknya bagi karyawan dalam jangka panjang!

3. Motivasi apakah yang paling sesuai digunakan dalam organisasi, motivasi positif atau motivasi negatif? Jelaskan! 
4. Gaya kepemimpinan apa yang paling sesuai ditetapkan pada perusahaan yang baru berdiri? Jelaskan!

5. Terangkan manfaat KKB dan collective bargaining!

6. Apa yang menyebabkan kompensasi menjadi sangat penting bagi proses pengintegrasian SDM? 


\section{Pemeliharaan}

\section{Sumber Daya Manusia}

\section{A. Pentingnya pemeliharaan SDM}

Pemeliharaan SDM adalah sebuah fungsi yang dimaksudkan sebagai suatu kegiatan manajemen untuk mempertahankan daya kerja SDM dalam melakukan pekerjaannya dalam perusahaan. Untuk memelihara daya kerja SDM maka perlu dilakukan usaha perlindungan fisik, jiwa dan raga para karyawan dari berbagai ancaman yang merugikan. Upaya pemeliharaan ini perlu dilakukan terus menerus karena SDM yang kurang mendapat perhatian dan pemeliharaan dari perusahaan akan menimbulkan masalah, semangat kerja dan prestasi karyawan akan merosot, loyalitas karyawan menurun. Jika hal ini terjadi maka akan berakibat pada tingginya tingkat kemangkiran (bolos) karyawan. Oleh karena itulah, suatu perusahaan yang ingin berkembang harus melakukan kegiatan pemeliharaan terhadap SDM yang bekerja diperusahaan. Karena pemeliharaan karyawan erat hubungannya dengan tingkat produktivitas karyawan terhadap suatu perusahaan. 
Menurut Hasibuan (2016), Pemeliharaan SDM adalah usaha mempertahankan dan atau meningkatkan kondisi fisik, mental, dan sikap karyawan agar mereka tetap loyal dan bekerja produktif untuk menunujang tercapainya tujuan perusahaan. Sementara tujuan dari pemeliharaan SDM, seperti yang dikemukakan Handoko (2015) adalah untuk:

1. Meningkatkan produktivitas karyawan

2. Meningkatkan disiplin dan menurunkan absensi karyawan.

3. Meningkatkan loyalitas dan menurunkan turnover karyawan.

4. Memberikan ketenangan, keamanan dan kesehatan karyawan.

5. Meningkatkan kesejahteraan karyawan dan keluarganya.

6. Memperbaiki kondisi fisik, mental, dan sikap karyawan.

7. Mengurangi konflik serta menciptakan suasana harmonis.

8. Mengefektifkan pengadaan karyawan. 


\section{B. Metode pemeliharaan}

Pemilihan metode yang tepat bertujuan agar pelaksanaannya efektif dalam mendukung tercapainya tujuan organisasi suatu perusahaan.

Menurut Hasibuan dalam bukunya yang berjudul “Manajemen Sumber Daya Manusia”, manajer seharusnya menerapkan metode yang sesuai dan efektif dalam melakukan tugas-tugasnya. Adapun metode-metode pemeliharaan antara lain:

1. Komunikasi

Komunikasi adalah proses pemindahan pengertian dalam bentuk gagasan atau informasi dari seseorang ke orang lain. Dalam menyampaikan informasi, komunikasi sangat diperlukan. Komunikasi berfungsi untuk instructive, informative, influencing, dan evaluative. Komunikasi disebut efektif jika informasi disampaikan secara singkat, jelas, dapat dipahami dan dilaksanakan sesuai dengan maksud komunikator. Melalui komunikasi yang baik dan efektif maka permasalaha-permasalahan yang terjadi di dalam perusahaan dapat diselesaikan. Konflik yang terjadi dapat diselesaikan melalui rapat dan 
musyawarah. Jadi, komunikasi sangat penting untuk menciptakan pemeliharaan karyawan dalam perusahaan.

Simbol-simbol komunikasi lain adalah suara, tulisan, gambar, warna, mimik, kedipan mata, dan lain-lain.

\section{Insentif}

Menurut Hasibuan dalam bukunya "Manajemen Sumber Daya Manusia", insentif adalah daya perangsang yang diberikan kepada karyawan tertentu berdasarakan prestasi kerjanya agar karyawan terdorong meningkatkan produktivitas kerjanya. Adapun jenis insentif dalam buku Hasibuan terbagi atas dua yaitu:

Insentif positif adalah daya perangsang dengan memberikan hadiah material atau non material kepada karyawan yang prestasi kerjanya di atas prestasi standar.

Insentif negatif adalah daya perangsang dengan memberikan ancaman hukuman kepada karyawan yang prestasi kerjanya di bawah prestasi standar. Selain jenisjenisnya, Insentif juga memiliki bentuk-bentuk insentif antara lain: 
Non material insentif, adalah daya perangsang yang diberikan kepada karyawan berbentuk penghargaan atau pengukuhan berdasarkan prestasi kerjanya. Misalnya piagam, piala, medali.

Sosial insentif, adalah daya perangsang yang diberikan pada karyawan berdasarkan prestasi kerjanya, berupa fasilitas dan kesempatan untuk mengembangkan kemampuannya, seperti promosi, mengikuti pendidikan atau naik haji.

Material insentif, adalah daya perangsang yang diberikan pada karyawan berdasarkan prestasi kerjanya, berbentuk uang dan barang. material insentif ini bernilai ekonomis sehingga dapat meningkatkan kesejahteraan karyawan dan keluarganya.Pemberian insentif yang adil dan terbuka akan menciptakan pemeliharaan yang baik dan selaras, sehingga loyalitas dan semangat kerja karyawan akan meningkat dan absensi serta tingkat keluar-masuk karyawan akan menurun. Jadi, pemberian insentif sangat berpengaruh terhadap kinerja karyawan dalam suatu perusahaan. 


\section{Program kesejahteraan}

Menurut Mangkuprawira (2011), kesejahteraan karyawan adalah balas jasa pelengkap (material dan non material) yang diberikan berdasarkan kebijaksanaan. Kesejaheraan yang diberikan sangatlah berarti dan bermanfaat untuk memenuhi kebutuhan fisik dan mental karyawan beserta keluarganya. Pemberian kesejahteraan akan menciptakan ketenangan, semangat kerja, dedikasi, disiplin, dan sikap loyal karyawan terhadap perusahaan sehingga labour turnover relatif rendah.

Pemberian kesejahteraan ini bertujuan mendorong agar tercapainya tujuan perusahaan, karyawan, dan masyarakat serta tidak melanggar peraturan legal pemerintah. Tujuan pemberian kesejahteraan adalah;

1. Untuk meningkatkan kesetiaan dan keterikatan karyawan kepada perusahaan.

2. Memberikan ketenangan dan pemenuhan kebutuhan bagi karyawan beserta keluarganya.

3. Memotivasi gairah kerja, disiplin, dan produktivitas kerja karyawan.

4. Menurunkan tingkat absensi dan turnover karyawan. 
5. Menciptakan lingkungan dan suasana kerja yang baik serta nyaman.

6. Membantu lancarnya pelaksanaan pekerjaan untuk mencapai kerjaan.

7. Memelihara kesehatan dan meningkatkan kualitas karyawan.

8. Mengefektifkan pengadaan karyawan.

9. Membantu membantu melaksanakan program pemerintah dalam meningkatkan kualitas manusia Indonesia.

10. Mengurangi kecelakaan dan kerusakan peralatan perusahaan.

11. Meningkatkan status sosial karyawan beserta keluarganya

Jenis-jenis kesejahteraan yang di berikan adalah finansial dan nonfinansial yang bersifat ekonomis, serta pemberian fasilitas dan pelayanan. Jenis kesejahteraan yang akan diberikan harus selektif dan efektif mendorong terwujudnya tujuan perusahaan, karyawan beserta keluarganya. Jadi, penentuan jenis kesejahteraan harus hati-hati, bukan secara emosional atau asal-asalan. 


\section{Manajemen Keselamatan dan kesehatan kerja (K3)}

Di negara berkembang seperti Indonesia, Undang- undang keselamatan kerja yang berlaku tidak secara otomatis meningkatkan kondisi di tempat kerja, disamping hukuman yang ringan bagi yang melanggar aturan. Meningkatkan standar keselamatan kerja yang lebih baik akan menghasilkan keuangan yang baik.

Tujuan dari sistem manajemen keselamatan dan kesehatan kerja adalah :

a) Sebagai alat mencapai derajat kesehatan tenaga kerja setinggi-tingginya, baik buruh, petani, nelayan, pegawai negeri, atau pekerja bebas.

b) Sebagai upaya mencegah dan memberantas penyakit dan kecelakaan akibat kerja, memelihara, menigkatkan kesehatan dan gizi tenaga kerja, merawat efisiensi dan daya produktivitas tenaga manusia, memberantas kelelahan kerja dan melipatgandakan gairah serta kenikmatan bekerja.

c) Memberi perlindungan kepada masyarakat sekitar perusahaan, agar terhindar dari bahaya pengotoran 
bahan proses indrustrialisasi yang bersangkutan, dan perlindungan masyarakat luas dari bahaya

\section{E. Faktor Keamanan Kerja}

Tujuan utama kesehatan dan keselamatan kerja adalah agar karyawan disebuah institusi mendapat kesehatan yang seoptimal mungkin sehingga mencapai produktivitas kerja yang setinggi-tingginya. Sedangkan tujuan diadakannya manajemen keselamatan kerja adalah agar para karyawan di sebuah institusi bebas dari segala kecelakaan akibat kerja atau gangguan-gangguan yang lain sehingga menurunkan dan bahwa mengakibatkan hilangnya produktivitas kerja. Untuk itu, maka diperlukan kondisi kerja yang kondusif terwujudnya derajat kesehatan dan terhindarnya kecelakaan kerja bagi karyawan sehingga disebut sebagai diterminan kesehatan dan keselamatan kerja yang antara lain mencakup:

\section{a. Beban kerja}

Setiap pekerjaan apapun memerlukan 2 hal penting yakni pekerjaan-pekerjaan yang lebih memerlukan pemikiran dan pekerjaan-pekerjaan yang lebih memerlukan kekuatan-kekuatan fisik. Kedua hal ini mempunyai keterbatasan-keterbatasan tersendiri. 
Siapapun juga tidak dapat dituntut dan dipaksakan untuk melaksanakan pekerjaannya melebihi kemampuan yang dimilikinya. Apabila seseorang dituntut dan dipaksakan untuk melakukan pekerjaan dapat terganggunya kesehatan atau terjadinya kecelakaan kerja bagi yang bersangkutan. Oleh sebab itu, kesehatan dan keselamatan kerja berusaha agar para karyawan baik yang menggunakan kemampuan pemikiran maupun fisiknya membuat perencanaan pelayanan terhadap kesehatan dan keselamatan kerja.

b. Beban tambahan

Beban tambahan bagi setiap tenaga kerja adalah lingkungan kerja yang tidak kondusif. Lingkungan kerja yang tidak kondusif sering bahkan selalu menghambat atau mempengaruhi kinerja dan pelaksanaan tugas karyawan. Lingkungan kerja sebagai beban tambahan karyawan di suatu institusi antara lain :

a. Faktor fisik, misalnya penerangan dalam lingkungan kerja yang tidak cukup, udara yang panas, pengap, kurangnya ventilasi dalam ruangan kerja, bising, 
ramai, kelembaban udara yang terlalu tinggi atau rendah dan sebagainya.

b. Faktor kimia, yaitu terganggunya lingkungan kerja dengan adanya bahan-bahan kimia yang menimbulkan bau tidak enak, bau gas, polusi kendaran bermotor, asap rokok, debu dan sebagainya.

c. Faktor biologi, yakni binatang atau serangga yang menggangu lingkungan kerja misalnya, lalat, nyamuk, kecoa, tanaman yang tidak teratur, lumut dan sebagainya.

d. Faktor fisiologis, yakni peralatan kerja yang tidak sesuai dengan ukuran tubuh, misalnya meja tulis atau komputer yang terlalu pendek atau tinggi, meja dan kursi rapat tidak sesuai ukuran dan sebagainya.

e. Faktor sosio-fisiologis, yakni suasana kerja yang tidak harmonis, misalnya adanya kelompokkelompok penggosip, adanya kecemburuan satu dengan yang lainnya dan sebagainya.

c. Kemampuan kerja 
Kemampuan kerja dalam mengerjakan tugasnya berbeda satu dengan yang lainnya. Meskipun pekerjaannya sama, dikerjakan oleh karyawan yang tingkat pendidikannya sama, tetapi hasilnya berbeda. Perbedaan hasil pekerjaan tersebut disebabkan karena perbedaan kemampuan yang dimiliki oleh para karyawan tersebut. Kemampuan seseorang dalam menjalankan tugasnya pada umumnya sejajar dengan prestasinya. Kemampuan dipengaruhi oleh banyak faktor, salah satunya adalah tingkat pendidikan. Faktor lainnya yang mempengaruhi kemampuan seseorang antara lain: kesehatan, status gizi, genetik, motivasi, latar belakang sosial, dan lingkungan. Tidak semua kemampuan harus ditingkatkan melalui pelatihan. Orang tidak mampu menjalankan tugasnya bukan karena tidak terampil tetapi karena mungkin tidak merasa fit atau karena kurang asupan makanan bergizi atau tidak punya motivasi untuk kerja.

\section{F. Hukum Industrial Pancasila}

Menurut Hasibuan dalam bukunya yang berjudul "Manajemen SDM", hubungan industrial pancasila adalah 
hubungan antara para pelaku dalam proses produksi barang dan jasa didasarakan atas nilai yang merupakan manifestasi dari keseluruhan sila-sila Pancasila dan UUD 1945, yang tumbuh dan berkembang di atas kepribadian bangsa dan kebudayaan nasional Indonesia. Berikut adalah ciri-ciri khusus Hubungan Industrial Pancasila antara lain:

1. Hubungan Industrial Pancasila mengakui dan menyakini bahwa bekerja bukan hanya bertujuan untuk sekedar mencari nafkah saja, akan tetapi sebagai pengabdian manusia kepada tuhannya, kepada sesama manusia, masyarakat, bangsa dan negara.

2. Hubungan Industrial Pancasila menganggap pekerja bukan hanya sekedar faktor produksi belaka, tetapi sebagai manusia pribadi dengan segala harkat dan martabatnya. Karena itu perlakuan pengusaha kepada pekerja bukan hanya dilihat dari segi kepentingan produksi belaka, akan tetapi haruslah dilihat dalam rangka meningkatkan harkat dan martabat manusia.

3. Hubungan Industrial Pancasila melihat antara pekerja dan pengusaha bukanlah mempunyai kepentingan yang bertentangan, akan tetapi mempunyai 
kepentingan yang sama yaitu kemampuan perusahaan. Karena dengan perusahaan yang maju dan semua pihak akan dapat meningkatkan kesejahteraan.

Tujuan Hubungan Industrial Pancasila di dalam mencapai tujuan mendasarkan diri pada asas-asas pembangunan nasional, yaitu:

i. Asas manfaat

ii. Asas usaha bersama dan kekeluargaan

iii. Asas demokrasi

iv. Asas adil dan merata

v. Asas keseimbangan

Hubungan Industrial Pancasila di dalam mecapai tujuan juga mendasarkan diri pada 3 asas kerja sama:

1)Buruh dan pengusaha pimpinan perusahaan adalah teman seperjuangan dalam proses produksi yang berarti baik buruh maupun pengusaha/pemimpin perusahaan wajib bekerja sama serta bantu membantu dalam kelancaran usaha dengan meningkatkan kesejahteraan dan menaikkan produksi. 
2)Buruh dan pengusaha/pemimpin perusahaan adalah teman seperjuangan keuntungan, yang berarti keuntungan yang diterima perusahaan dinikmati bersama dengan bagian yang layak dan serasi.

3)Buruh dan pengusaha/pemimpin perusahaan adalah teman seperjuangan dalam mempertanggung jawabkan kepada: (1) Tuhan Yang Maha Esa, (2) Bangsa dan Negara, (3) Masyarakat sekelilingnya. (4) Buruh beserta keluarganya, dan (5) Perusahaan tempat mereka bekerja.

Dengan demikian, dalam HIP tidak ada tempat bagi sikap saling berhadap-hadapan atau penindasan oleh yang kuat terhadap yang lemah. Jadi, HIP juga mewujudkan terciptanya pemeliharaan karyawan yang baik. Dalam HIP setiap perbedaan pendapat antara pekerja dan pengusaha harus diselesaikan dengan jalan musyawarah untuk mencapai mufakat yang dilakukan secara kekeluargaan. Didasari hal tersebut, penggunaan tindakan penekanan dan aksi-aksi sepihak seperti mogok dan penutupan perusahaan tidak sesuai dengan prinsip-prinsip Hubungan Industrial. 


\section{G. Soal Soal}

1. Jelaskan pentingnya pemeliharaan SDM bagi organisasi!

2. Terangkan metode dalam pemeliharaan SDM yang umum digunakan!

3. Mengapa Program Kesejahteraan sangat penting dirancang seadil dan selayak mungkin? Jelaskan!

4. Jelaskan tujuan dari K3!

5. Jelaskan faktor apa saja yang mempengaruhi keselamatan dan keamanan karyawan di tempat kerja!

6. Menurut pendapat Anda, apakah Hubungan Industrial Pancasila telah berjalan di Indonesia atau belum? Terangkan! 
Perencanaan

Sumber Daya Manusia

\section{G. Pentingnya perencanaan SDM}

Fungsi dari perencanaan sumber daya manusia adalah untuk mendapatkan dan memelihara kualifikasi sumber daya manusia yang dibutuhkan bagi organisasi perusahaan dalam mencapai tujuan perusahaan. Perencanaan SDM memiliki hubungan terintegrasi dengan manajemen SDM. Mengunakan informasi berbagai aktifitas SDM. Sehingga Perencanaan SDM dipandang bukan hanya sekedar fungsi personalia namun sebagai suatu proses manajemen.

Komponen Utma dalam perencanaan sumber daya manusia adalah penentuan tipe sumber daya manusia yang dibutuhkan suatu organisasi atau perusahaan dalam jangka waktu tertentu. Perencanaan SDM merupakan kegiatan mengidentifikasi jumlah sumber daya manusia yang dibutuhkan organisasi untuk mencapai tujuan di masa depan. Untuk menyusun rencana tenaga kerja, seorang manajer SDM akan memproyeksikan penawaran dan permintaan terhadap 
SDM. Perencanaan lalu menentukan perbedaan antara permintaan dengan suplai, yakni terdapat kekurangan atau kelebebihan.

terdapat beberapa tujuan bagi organisasi untuk melakukan perencanaan sumber daya manusia agar perusahaan dapat berjalan secara efektif dan efisien. Berikut tujuannya:

1. Memutuskan Kualitas dan kuantitas katryawan yang aan mengisi jabatan dalam perusahaan.

2. Menjamin tersedianya tenaga kerja masa kini maupun masa yang akan datang sehingga setiap pos pekerjaan terdapat SDM yang berkompeten mengisinya.

3. Menghindari terjadinya mis Manajemen dan tumpang tindih dalam pelaksanaan tugas.

4. Mempermudah koordinasi, integrasi, dan sinkronisasi sehingga produktivitas kerja meningkat.

5. Menghindari kekurangan dan kelebihan karyawan.

6. Menjadi pedoman dalam melaksanakan mutasi dan pensiun karyawan. 
7. Menjadi pedoman dalam menetapkan program penarikan seleksi pengembangan, kompensasi, pemeliharaan, kedisiplinan dan pemberhentian karyawan.

8. Menjadi dasar dalam melakukan pemilihan karyawan

Dapat dikatakan bahwa perencanaan SDM memiliki peranan strategis dalam organisasi. Peranan strategis tersebut adalah:

a. Untuk memastikan bahwa sejumlah pekerja dalam jumlah tertentu memenuhi persyaratan yang dibutuhkan pada kurun waktu tertentu.

b. Organisasi dapat mengidentifikasi segala kegiatan Manajemen SDM yang dibutuhkan guna memastikan adanya karyawan berkualitas yang sesuai dengan kebutuhan dalam rangka mencapai tujuan organisasi. 


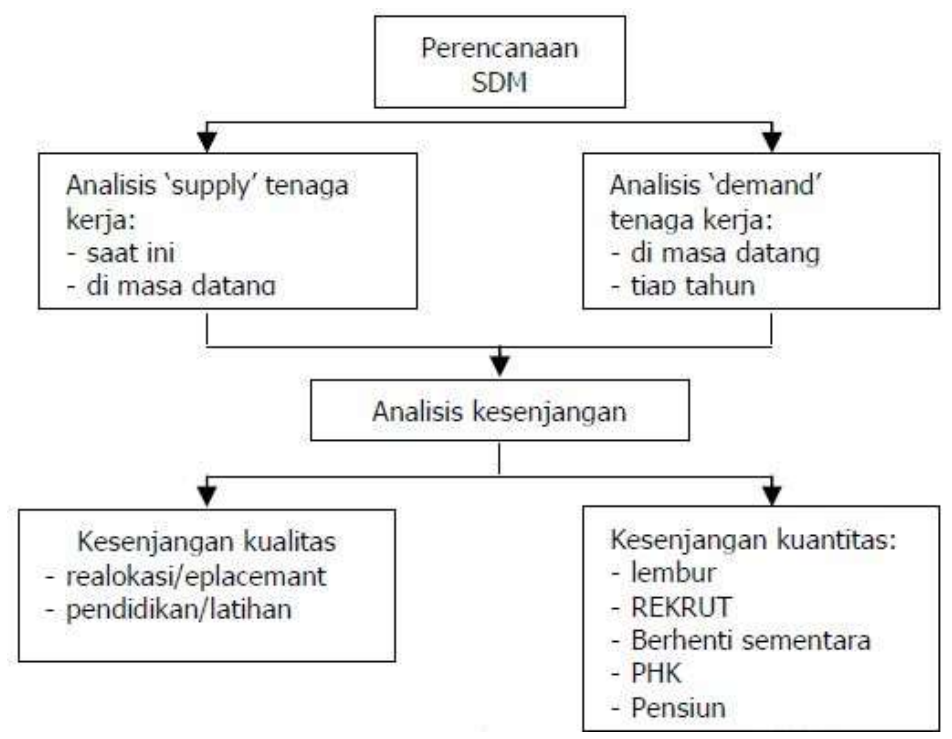

Gambar 7.1 Proses Perencanaan SDM

\section{H. Metode, informasi, dan peramalan SDM}

Strategi SDM adalah alat yang digunakan untuk membantu organisasi untuk mengantisipasi dan mengatur penawaran dan permintaan SDM. Strategi SDM ini memberikan arah secara keseluruhan mengenai bagaimana kegiatan SDM akan dikembangkan dan dikelola.

Pengembangan rencana SDM merupakan rencana jangka panjang. Contohnya, dalam perencanaan SDM suatu organisasi harus mempertimbangkan alokasi orang-orang pada tugasnya untuk jangka panjang tidak hanya enam bulan 
kedepan atau hanya untuk tahun kedepan. Alokasi ini membutuhkan pengetahuan untuk dapat meramal kemungkinan apa yang akan terjadi kelak seperti perluasan, pengurangan pengoperasian, dan perubahan teknologi yang dapat mempengaruhi organisasi tersebut.

Metode Perencanaan SDM dikenal atas dua metode: metode nonilmiah, diartikan bahwa perencanaan SDM hanya didasarkan atas pengalaman, imajinasi, dan perkiraanperkiraan dari perencanaanya saja. Rencana SDM semacam ini risikonya cukup besar, misalnya kualitas dan kuantitas tenaga kerja tidak sesuai dengan kebutuhan perusahaan. Akibatnya timbul mismanajemen dan pemborosan yang merugikan perusahaan.

Yang kedua adalah metode ilmiah, diartikan bahwa Perencanaan SDM dilakukan berdasarkan atas hasil analisis dari data, informasi, dan peramalan (forecasting) dari perencananya. Rencana SDM semacam ini risikonya relatif kecil karena segala sesuatunya telah diperhitungkan terlebih dahulu.

Penekanan utama dari peramalan SDM saat ini adalah meramalkan kebutuhan SDM organisasi atau permintaan 
kebutuhan akan SDM. Ramalan permintaan dapat berupa penilaian subjektif atau matematis.

1. Metode subjektif terdiri dari:

i. Estimasi; top down atau bottom up.

ii. Rules of thumb

2. Metode Matematika, terdiri dari:

i. Analisis Regresi Statistik

ii. Merode Simulasi

iii. Rasio Produktivitas

iv. Rasio jumlah tenaga kerja yang dibutuhkan

\section{Prosedur dan perencanaan SDM}

Pengembangan rencana SDM merupakan rencana jangka panjang. Contohnya, dalam perencanaan SDM suatu organisasi harus mempertimbangkan alokasi orang-orang pada tugasnya untuk jangka panjang tidak hanya enam bulan kedepan atau hanya untuk tahun kedepan.

Alokasi ini membutuhkan pengetahuan untuk dapat meramal kemungkinan apa yang akan terjadi kelak seperti perluasan, pengurangan pengoperasian, dan perubahan teknologi yang dapat mempengaruhi organisasi tersebut. 
Dan yang perlu diketahui dalam pengembangan rencana SDM ini adalah Prosedur perencanaan SDM yang seperti ada di bawah ini:

1. Menetapkan secara jelas kualitas dan kuantitas SDM yang dibutuhkan.

2. Mengumpulkan data dan informasi tentang SDM.

3. Mengelompokkan data dan informasi serta menganalisisnya.

4. Menetapkan beberapa alternatif.

5. Memilih yang terbaik dari alternatif tersedia.

6. Menginformasikan rencana kepada para karyawan untuk direalisasikan.

Perencanaan SDM harus dimulai dari pendayagunaan secara efektif dan efisien (optimal) SDM yang sudah dimiliki; dan hanya akan menambah atau merekrut SDM dari luar apabila ternyata terdapat kekurangan SDM untuk melaksanakan tugas-tugas pokok perusahaan.

Meskipun perencanaan SDM disusun oleh Staf MSDM Supervisor MSDM, atau Manager SDM, namun perlu dipahami bahwa kebutuhan pegawai tidak bisa dilepaskan dari kebutuhan departemen / divisi dalam perusahaan dan 
rencana strategis organisasi dalam beberapa tahun ke depan. di samping kebutuhan yang sifatnya didasarkan kepada aspek operasional organisasi saat ini. Dengan demikian dalam melakukan perencanaan SDM, karena perencanaan SDM bersifat divisional, seorang HR yang cerdas akan bersinergi terlebih dahulu ke berbagai pihak / divisi / departemen lain dalam organisasi agar perencanaan SDM dapat berjalan semaksimal mungkin.

\section{J. Sumber penarikan SDM}

Mangkunegara (2011) mengemukakan bahwa terdapat Ada dua sumber dalam penarikan pegawai, yaitu sumber dari dalam perusahaan dan sumber dari luar perusahaan.

1. Sumber dari Dalam Perusahaan

Upaya penarikan pegawai dapat dilakukan melalui proses memutasikan pegawai berdasarkan hasil evaluasi terhadap penilaian prestasi kerja dan kondite pegawai yang ada di perusahaan. Ada tiga bentuk mutasi pegawai, yaitu: 
1) Promosi jabatan, yaitu pemindahan pegawai dari satu jabatan ke tingkat jabatan yang lebih tinggi daripada jabatan sebelumnya.

2) Transfer atau rotasi pekerjaan adalah pemindahan bidang pekerjaan pegawai kepada bidang pekerjaan lainnya tanpa mengubah tingkat jabatannya.

3) Demosi jabatan adalah penurunan jabatan pegawai dari satu jabatan ke tingkat jabatan yang lebih rendah atas dasar kondite dan prestasi kerjanya atau akibat terjadinya penyederhanaan struktur organisasi.

\section{Sumber dari Luar Perusahaan}

Sumber ini mengambil calom karyawan yang akan mengisi jabatan yang lowong dilakukan penarikan dari sumbersumber tenaga kerja di luar perusahaan yaitu :

1) Iklan Media Massa, sebagai sumber penawaran formasi kerja kepada masyarakat luas. Dengan demikan, memungkinkan perusahaan dapat menyeleksi calon pegawai yang betul-betul memenuhi persyaratan 
kualifikasi sesuai yang dibutuhkan untuk mengisi formasi yang ada di perusahaan.

2) Lembaga Pendidikan, perusahaan memanfaatkan lembaga pendidikan sebagai sumber penarikan pegawai. Calon pegawai yang mendapat rekomendasi dari lembaga pendidikan pada umumnya merupakan calon pegawai yang mempunyai prestasi akademik yang tinggi dan mempunyai kepribadian yang dinilai baik selama mereka menempuh pendidikan di lembaga pendidikan tersebut.

3) Depnaker, perusahaan dapat memanfaatkan calon pegawai yang mendapat rekomendasi dari Departemen Tenaga Kerja

4) Lamaran Kerja yang sudah masuk di Perusahaan. Melalui lamaran kerja yang sudah masuk, perusahaan dapat langsung menyeleksi lamaran yang memenuhi syarat untuk mengisi posisi di perusahaan.

\section{K. Prosedur dan tata cara Audit SDM}

Audit merupakan proses pengumpulan dan pengevaluasian bahan bukti tentang informasi yang dapat 
diukur mengenai suatu entitas ekonomi yang dilakukan seorang yang kompeten dan independen untuk dapat menentukan dan melaporkan kesesuaian informasi dengan kriteria-kriteria yang telah ditetapkan. Sedang audit SDM adalah pemeriksaan kualitas kegiatan SDM secara menyeluruh dalam suatu departemen, divisi atau perusahaan, dalam arti mengevaluasi kegiatan-kegiatan SDM dalam suatu perusahaan dengan menitikberatkan pada peningkatan atau perbaikan (Handoko, 2016).

Sedangkan menurut Wibowo (2016), audit sumber daya manusia merupakan tinjauan berkala yang dilakukan oleh departemen sumber daya manusia untuk mengukur efektifitas penggunaan sumber daya manusia yang terdapat di dalam suatu perusahaan. Selain itu, audit memberikan suatu perspektif yang komprehensif terhadap praktik yang berlaku sekarang, sumber daya, dan kebijakan manajemen mengenai pengelolaan SDM serta menemukan peluang dan strategi untuk mengarahkan ulang peluang dan strategi tersebut. Intinya, melalui audit dapat menemukan permasalahan dan memastikan kepatuhan terhadap berbagai peraturan perundangan-undangan dan rencana-rencana strategis perusahaan. 
Audit SDM merupakan suatu metode evaluasi untuk menjamin bahwa potensi SDM dikembangkan secara optimal. Secara lebih terinci, menurut Mathis \& Jackson (2012), audit SDM juga memberi feedback dan kesempatan untuk:

a. Mengevaluasi keefektifan berbagai fungsi SDM yang meliputi rekrutmen dan seleksi, pelatihan dan penilaian kinerja.

b. Menganalisis kontribusi fungsi SDM pada operasi bisnis perusahaan.

c. Melakukan benchmarking kegiatan SDM untuk mendorong perbaikan secara berkelanjutan.

d. Mengidentifikasi berbagai masalah strategi dan administratif implementasi fungsi SDM.

e. Menganalisis kepuasan para pengguna pelayanan departemen SDM.

f. Mengevaluasi ketaatan terhadap berbagai peraturan perundang-undangan, kebijakan dan regulasi pemerintah.

g. Meningkatkan keterlibatan fungsi lini dalam implementasi fungsi SDM. 
h. Mengukur dan menganalisis biaya dan manfaat setiap program dan kegiatan SDM

i. Memperbaiki kualitas staf SDM.

j. Memfokuskan staf SDM pada berbagai isu penting dan mempromosikan perubahan serta kreatifitas.

\section{Soal Soal}

1. Jelaskan pentingnya perencanaan SDM bagi organisasi!

2. Jelaskan menurut pendapat Anda, mana metode peramalan perencanaan SDM yang paling cocok digunakan pada perusahaan besar!

3. Jelaskan prosedur perencanaan SDM!

4. Dari sumber apa saja perencanaan SDM dapa dilakukan? Jelaskan!

5. Menurut Anda, apa manfaat dari audit SDM? Jelaskan! 


\section{Kedisiplinan dan}

Kepuasan Kerja

\section{H. Pentingnya Kedisiplinan dan Motivasi Kerja}

Pengertian Disiplin Kerja Menurut pendapat Mangkuprawira (2011) adalah suatu sikap tingkah laku dan perbuatan yang sesuai dengan peraturan dari perusahaan baik tertulis maupun tidak tertulis. Handoko (2015) membagi 3 disiplin kerja(1994:208) yaitu:

a. Displin Preventif yaitu: kegiatan yang dilaksanakan untuk mendorong para karyawan agar mengikuti berbagai standar dan aturan, sehingga penyelewengan dapat dicegah.

b. Disiplin Korektif yaitu: kegiatan yang diambil untuk menangani pelanggaran terhadap aturan-aturan yang mencoba untuk menghindari pelanggaranpelanggaran lebih lanjut. Kegiatan korektif sering berupa suatu bentuk hukuman dan disebut tindakan pendisiplin.

c. Disiplin Progresif yaitu: kegiatan memberikan hukuman-hukuman yang lebih berat terhadap 
pelanggaran-pelanggaran yang berulang. Tujuan dari disiplin progresif ini agar karyawan untuk mengambil tindakan-tindakan korektif sebelum mendapat hukuman yang lebih serius.

Banyak faktor yang dapat mempengaruhi tegak tidaknya suatu disiplin kerja dalam suatu perusahaan. Menurut Wibowo (2016), faktor-faktor tersebut antara lain:

1. Besar kecilnya pemberian kompensasi

2. Ada tidaknya keteladanan pimpinan dalam perusahaan

3. Ada tidaknya aturan pasti yang dapat dijadikan pegangan

4. Keberanian pimpinan dalam mengambil tindakan

5. Ada tidaknya pengawasan pimpinan

6. Ada tidaknya perhatian kepada pada karyawan

7. Diciptakan kebiasaan-kebiasaan yang mendukung tegaknya disiplin

Adalah satu tugas yang paling sulit bagi seorang atasan adalah bagaimana menegakkan disiplin kerja secara tepat. Jika karyawan melanggar aturan tata tertib, seperti terlalu sering terlambat atau membolos kerja, berkelahi, tidak jujur atau bertingkah laku lain yang dapat merusak kelancaran kerja 
suatu bagian, atasan harus turun tangan. Kesalahan semacam itu harus dihukum dan atasan harus mengusahakan agar tingkah laku seperti itu tidak terulang.

Terdapat beberapa cara menegakkan disiplin kerja dalam suatu perusahaan menurut Wibowo (2016):
a. Disiplin Harus Ditegakkan Seketika
b. Disiplin Harus Didahului Peringatan Dini
c. Disiplin Harus Konsisten
d. Disiplin Harus Impersonal
e. Disiplin Harus Setimpal

Berikutnya pada motivasi kerja, Mello (2014) berpendapat bahwa motivasi kerja adalah kondisi yang berpengaruh membangkitkan, mengarahkan dan memelihara perilaku yang berhubungan dengan lingkungan kerja. Sedangkan menurut Aguinis (2015), Motivasi kerja adalah kemauan kerja karyawan yang timbulnya karena adanya dorongan dari dalam pribadi karyawan yang bersangkutan sebagai hasil integrasi keseluruhan daripada kebutuhan pribadi, pengaruh lingkungan fisik dan pengaruh lingkungan sosial dimana kekuatannya tergantung daripada proses pengintegrasian tersebut. 
Menurut pendapat diatas, dapat disimpulkan bahwa motivasi kerja adalah suatu faktor yang mendorong seorang karywan untuk melakukan suatu perbuatan atau kegiatan tertentu, oleh karena itu motivasi sering kali diartikan pula sebagai faktor pendorong perilaku seseorang. Setiap tindakan yang dilakukan oleh seorang manusia pasti memiliki sesuatu faktor yang mendorong perbuatan tersebut. Motivasi atau dorongan untuk bekerja ini sangat penting bagi tinggi rendahnya produktivitas perusahaan. Tanpa adanya motivasi dari para karyawan atau pekerja untuk bekerja sama bagi kepentingan perusahaan maka tujuan yang telah ditetapkan tidak akan tercapai. Sebaliknya apabila terdapat motivasi yang besar dari para karyawan maka hal tersebut merupakan suatu jaminan atas keberhasilan perusahaan dalam mencapai tujuannya.

Motivasi atau dorongan kepada karyawan untuk bersedia bekerja bersama demi tercapainya tujuan bersama ini terdapat dua macam, yaitu:

d. Motivasi finansial, yaitu dorongan yang dilakukan dengan memberikan imbalan finansial kepada karyawan. Imbalan tersebut sering disebut insentif. 
e. Motivasi nonfinansial, yaitu dorongan yang diwujudkan tidak dalam bentuk finansial/ uang, akan tetapi berupa hal-hal seperti pujian, penghargaan, pendekatan manusia dan lain sebagainya (Handoko, 2016).

Menurut Aguinis (2015), memotivasi bawahan berarti menjadikan mereka merasakan bahwa bekerja sebagai bagian hidup yang dinikmati. Para pekerja pada umumnya akan siap bekerja keras bila menghadapi beberapa kondisi berikut ini:

1. Merasa diperlukan oleh organisasi

2. Mengetahui yang diharapkan organisasi

3. Perlakuan adil antar pekerja dan dalam pemberian imbalan

4. Peluang untuk berkembang

5. Tantangan yang menarik

6. Suasana kerja yang menyenangkan

\section{Indikator indikator kedisiplinan}

Menurut Hasibuan (2005) Kedisiplinan merupakan fungsi operatif MSDM yang terpenting karena semakin baik disiplin karyawan, semakin tinggi prestasi kerja yang dapat dicapainya. Tanda disiplin karyawan baik, sulit bagi organisasi perusahaan mencapai hasil yang optimal. Disiplin yang baik 
mencerminkan besarnya rasa tanggung jawab seseorang terhadap tugastugas yang diberikan kepadanya. Hal ini mendorong gairah kerja, semangat kerja, dan terwujudnya tujuan perusahaan, karyawan, dan masyarakat. Oleh karena itu, setiap manajer selalu berusaha agar para bawahannya mempunyai disiplin yang baik. Seorang manajer dikatakan efekif dalam kepemimpinannya, jika para bawahannya berdisiplin baik. Untuk memelihara dan meningkatkan kedisiplinan yang baik adalah hal yang sulit, karena banyak faktor yang mempengaruhinya.

Menurut Hasibuan (2016) Pada dasarnya banyak indikator yang mempengaruhi kedisiplinan karyawan suatu organisasi, diantaranya:

1. Tujuan Dan Kemampuan

Tujuan dan kemampuan ikut mempengaruhi tingkat kedisiplinan karyawan. Tujuan yang akan dicapai harus jelas dan ditetapkan secara ideal serta cukup menantang bagi kemampuan karyawan

2. Teladan Pimpinan

Teladan pimpinan sangat berperan dalam menentukan kedisiplinan karyawan karena pimpinan dijadikan teladan dan panutan oleh para bawahannya. 
3. Balas Jasa

Balas jasa (gaji dan kesejahteraan) ikut mempengaruhi kedisiplinan karyawan karena balas jasa akan memberikan kepuasan dan kecintaan karyawan terhadap perusahaan/pekerjaannya.

4. Keadilan

Keadilan ikut mendorong terwujudnya kedisiplinan karyawan, karena ego dan sifat manusia yang selalu merasa dirinya penting dan minta diperlakukan sama dengan manusia lainnya.

5. Waskat

Waskat ialah tindakan nyata dan efektif untuk mencegah/mengetahui kesalahan, membetulkan kesalahan, memelihara kedisiplinan, meningkatkan prestasi kerja, mengaktifkan peranan atasan dan bawahan, menggali sistem-sistem kerja yang paling efektif, serta menciptakan sistem internal control yang terbaik dalam mendukung terwujudnya tujuan perusahaan, karyawan dan masyarakat.

6. Sanksi Hukuman

Dengan sanksi hukuman yang semakin berat, karyawan akan semakin takut melanggar peraturan- 
eraturan perusahaan, sikap dan perilaku indisipliner karyawan akan berkurang. Berat ringannya sanksi hukuman yang akan diterapkan ikut mempengaruhi baik/buruknya kedisiplinan karyawan. Sanksi hukuman harus dipertimbangkan secara logis, masuk akal dan diinformasikan secara jelas kepada semua karyawan.sanksi hukuman seharusnya tidak terlalu ringan, namun juga tidak terlalu berat agar dapat tetap mendidik karyawan untuk mengubah perilakunya.

7. Hubungan Kemanusiaan

Hubungan kemanusiaan yang harmonis di antara karyawan ikut menciptakan kedisiplinan yang baik pada suatu perusahaan. Manajer harus berusaha menciptakan suasana hubungan kemanusiaan yang serasi serta mengikat, vertikal maupun horizontal di antara semua karyawannya. Terciptanya human relationship yang serasi akan mewujudkan lingkungan dan suasana kerja yang nyaman.

\section{J. Persaingan dan konflik dalam organisasi}

Menurut Hasibuan (2005: 198-201) Persaingan adalah kegiatan yang berdasarkan atas sikap rasional dan emosional dalam mencapai prestasi kerja yang terbaik. Persaingan 
dimotivasi oleh ambisi untuk memperoleh pengakuan, penghargaan, dan status sosial yang terbaik.

Konflik adalah pesaingan yang kurang sehat berdasarkan ambisi dan sikap emosional dalam memperoleh kemenangan. Konflik akan menimbulkan ketegangan, konfrontasi, perkelahian dan frustasi jika tidak dapat diselesaikan. Hal-hal yang menyebabkan persaingan dan konflik, antara lain:

1. Tujuan. Tujuan yang ingin dicapai akan merangsang timbulnya persaingan dan konflik di antara individu atau kelompok karyawan. Setiap karyawan atau kelompok selalu berjuang untuk mencapai pengakuan yang lebih baik dari orang lain.

2. Ego Manusia. Ego manusia yang selalu menginginkan lebih berhasil dari manusia lain akan menimbulkan persaingan atau konflik.

3. Kebutuhan. Kebutuhan material dan non material yang terbatas akan menyebabkan timbulnya persaingan atau konflik. Pada dasarnya setiap orang menginginkan pemenuhan kebutuhan material dan non 
material. Yang lebih baik dari orang lain sehingga timbullah persaingan dan konflik.

4. Perbedaan Pendapat. Perbedaan pendapat akan menimbulkan persaingan atau konflik. Karena setiap orang atau kelompok terlalu mempertahankan bahwa pendapatnya itulah yang paling tepat. Jika perbedaan pendapat tidak terselesaikan, akan timbul persaingan atau konflik yang kadang-kadang menyebabkan perpecahan.

5. Salah Paham. Salah paham sering terjadi di antara orang-orang yang bekerja sama. Karena salah pham(salah persepsi) ini timbullah persaingan dan konflik di antara individu karyawan atau kelompok.

6. Perasaan Dirugikan. Perasaan dirugikan karena perbuatan orang lain akan menimbulkan persaingan atau konflik. Setiap orang tidak dapat menerima kerugian dari perbuatan orang lain. Oleh kaena itu, perbuatan yang merugikan orang ain hendaknya dicegah supaya tidak timbul konflik di atara sesamanya. Jika terjadi konflik 
pasti akan merugikan kedua belah pihak, bahkan akan merusak kerja sama.

7. Perasaan Sensitif. Perasaan sensitif atau mudah tersinggung akan menimbulkan konflik. Perilaku atau sikap seseorang dapat menyinggung perasaan orang lain yang dapat menimbulkan konflik atau perselisihan, bahkan dapat menimbulkan perkelahian di antara karyawan. Konflik terjadi karena harga dirinya tersinggung walaupun menurut orang lain tidak ada maksud jelek. Akan tetapi karena perasaan sensitif seseorang hal itu dianggap menghina.

Seperti sisi koin, setiap persaingan / konflik yang terjadi dapat membawa keuntungan atau kerugian

Kebaikan ersaingan

- Evaluasi diri demi kemajuan.

- Prestasi kerja akan meningkat.

- Mengembangkan diri demi kemajuan karena dorongan persaingan.

- Memotivasi dinamika organisasi dan kreativitas karyawan. 
Keburukan persaingan

- Kerja sama kurang serasi dan harmonis di antara para karyawan.

- Memotivasi sikap-sikap emosional karyawan.

- Menimbulkan sikap apriori karyawan.

- Meningkatkan absen dan turnover karyawan.

- Kerusakan produksi dan kecelakaan semakin meningkat.

\section{K. Kepuasan kerja, stres, dan frustasi}

Menurut Hasibuan (2016) Kepuasan kerja adalah sikap emosional yang menyenangkan dan mencintai pekerjaannya. Sikap ini dicerminkan oleh moral kerja, kedisiplinan, dan prestasi kerja. Kepuasan kerja dinikmati dalam pekerjaan, luar pekerjaa, dan kombinasi dalam dan luar pekerjaan.

Kepuasan kerja karyawan dipengaruhi oleh faktor-faktor berikut :

1. Balas jasa yang adil dan layak.

2. Penempatan yang sesuai dengan keahliannya.

3. Berat-ringannya pekerjaan.

4. Suasana dan lingkungan pekerjaan.

5. Peralatan yang menunjang pelaksanaan pekerjaan.

6. Sikap pemimpin dalam kepemimpinannya. 
7. Sikap pekerjaan monoton atau tidak.

Menurut Handoko (2015) Pada dasarnya kepuasan kerja berarti tanggapan emosional seseorang terhadap aspek-aspek didalam atau pada keseluruhan pekerjaan/jabatannya.

Stres karyawan timbul akibat kepuasan kerja tidak terwujud dari pekerjaannya. Stres karyawan perlu sedini mungkin diatasi oleh pemimpin agar hal-hal yang dapat merugikan perusahaan dapat segera diatasi. Stres adalah kondisi ketegangan yang mempengaruhi emosi, proses berfikir, dan kondisi seseorang. Orang-orang yang mengalami stres menjadi nervous dan merasa kekuatiran kronis. Mereka sering menjadi marah-marah, agresif, tidak dapat rileks, atau memperlihatkan sikap yang tidak kooperatif.

Faktor-faktor penyebab stres karyawan, antara lain sebagai berikut:

1. Beban kerja yang sulit dan berlebihan.

2. Tekanan dan sikap pemimpin yang kurang adil dan wajar.

3. Waktu dan peralatan kerja yang kurang memadahi.

4. Konflik antara pribadi dengan pemimpin atau kelompok kerja.

5. Balas jasa yang terlalu rendah. 
6. Masalah-masalah keluarga seperti anak, istri, mertua dan lain-lain.

7. Frustrasi

Stres karyawan yang belum terselesaikan dengan baik akan mengakibatkan timbulnya frustrasi. Frustrasi akan menimbulkan perilaku yang aneh-aneh dari orang tersebut, misalnya marah-marah, membanting telepon, bahkan memukul-mukul kepalanya. Frustrasi adalah keadaan emosional, ketegangan pikiran dan perilaku yang tidak terkendalikan dari seseorang, bertindak aneh-aneh yang dapat membahayakan dirinya atau orang lain.

\section{Bimbingan Konseling Karyawan untuk}

\section{Meningkatkan Kedisiplinan}

Aguinis (2016) menjelaskan bahwa konseling adalah suatu pertemuan langsung dengan individu yang ditujukan pada pemberian bantuan kapadanya untuk dapat menyesuaikan dirinya secara lebih efektif dengan dirinya sendiri dan lingkungan. Wibowo (2016) menjelaskan definisi konseling sebagai proses pemberian bantuan yang dilakukan melalui wawancara konseling oleh seorang ahli (disebut konselor) kepada individu yang sedang mengalami sesuatu masalah 
(disebut klien) yang bermuara pada teratasinya masalah yang dihadapi klien.

Konseling dilakukan untuk memajukan kesehatan mental yang baik bagi karyawan, yaitu:

1. Merasa nyaman dengan dirinya sendiri.

2. Pandangan yang obyektif tentang orang lain.

3. Dapat memenuhi kebutuhan hidup.

Terdapat 3 jenis konseling yang dapat digunakan untuk menyehatkan mental SDM di sebuah organisasi:

1. Directive Counseling (Conselor Centered)

Konselor memutuskan apa yang harus dilakukan, memberitahu dan memotivasi untuk melakukan halhal tertentu (terpusat pada konselor, dia yang lebih aktif dan otoriter).

2. Non Directive Counseling (Councelee Centered) Konselee dapat membuat keputusan, pemecahan dari konselee, konselor menumbuhkan insight, dapat lebih mendewasakan konselee.

3. Participative Counseling

Kedua belah pihak berpartisipasi saling mengembangkan pemecahan masalahnya. Ada kerjasama yang kooperatif (diskusi bersama). 


\section{Menejemen performa untuk meningkatkan kedisplinan}

Manajemen performa menurut Aguinis (1998), Manajemen Kinerja merupakan pendekatan strategis dan terintegrasi untuk memberikan hasil yang sukses dalam organisasi dengan meningkatkan kinerja dan mengembangkan kemampuan tim dan individu. Sementara tujuan utama dari Manajemen performa secara keseluruhan adalah memastikan semua elemen organisasi atau perusahaan bekerjasama secara terpadu untuk mencapai tujuan organisasinya.

Secara terperinci, Wibowo (2016) berpendapat bahwa fungsi manajemen performa yang memiliki dampak signifikan dalam peningkatan kedisiplinan karyawan pada sebuah organisasi adalah sebagai berikut:

a. Membantu karyawan dalam mengidentifikasi pengetahuan dan keterampilan yang diperlukan untuk melakukan pekerjaannya secara efisien dan juga dapat mendorong mereka untuk melakukan tugas yang benar dengan cara yang benar. 
b. Meningkatkan kinerja karyawan dengan mendorong pemberdayaan karyawan, motivasi dan penerapan mekanisme penghargaan (rewards) yang efektif.

c. Meningkatkan sistem komunikasi dua arah antara Supervisor/Manajer dan karyawan untuk dapat memperjelas ekspektasi (harapan) perusahaan mengenai peran dan akuntabilitas karyawan dalam melakukan pekerjaan, mengkomunikasikan tujuan fungsional dan organisasi serta memberikan umpan balik yang teratur dan transparan sehingga dapat meningkatkan kinerja karyawan dan pembinaan berkelanjutan.

d. Mengidentifikasi hambatan untuk kinerja yang efektif dan menyelesaikan hambatan tersebut melalui pemantauan (monitoring), pembinaan (coaching) dan pengembangan (development).

e. Menciptakan dasar untuk beberapa keputusan administratif mengenai perencanaan strategis, perencanaan suksesi (succession planning), promosi, kompensasi dan pengupahan yang berdasarkan kinerja. 
f. Meningkatkan pengembangan diri pribadi karyawan dan kemajuan dalam karir karyawan dengan membantu mereka memperoleh pengetahuan dan keterampilan yang diinginkan.

\section{N. Soal Soal}

1. Jelaskan secara singkat pentingnya kedisiplinan dalam organisasi!

2. Jelaskan secara ringkas indikator indikator kedisiplinan!

3. Jelaskan kebaikan konflik dalam organisasi!

4. Apa kegunaan bimbingan konseling bagi karyawan? Jelaskan!

5. Terangkan mengenai manajemen performa dan kegunaannya bagi kedisiplinan karyawan! 


\section{Pemberhentian Karyawan}

\section{G. Pentingnya Pemberhentian Tenaga Kerja}

Istilah pemberhentian juga mempunyai arti yang sama dengan separation yaitu pemisahan. Pemberhentian juga bisa berarti Pemutusan Hubungan Kerja (PHK) karyawan dari suatu organisasi perusahaan. Pemberhentian yang dilakukan oleh perusahaan harus berdasarkan dengan Undang - undang No 12 Tahun 1964 KUHP dan seijin P4D atau P4P atau seijin keputusan pengadilan. Pemberhentian juga harus memperhatikan pasal 1603 ayat 1 KUHP yaitu mengenai "tenggang waktu dan ijin pemberhentian". Perusahaan yang melakukan pemberhentian akan mengalami kerugian karena karyawan yang diberhentikan membawa biaya penarikan, seleksi, pelatihan dan proses produksi berhenti.

Pemberhentian yang dilakukan oleh perusahaan juga harus dengan baik - baik, mengingat saat karyawan tersebut masuk juga diterima baik - baik. Dampak pemberhentian bagi karyawan yang diberhentikan yaitu dampak secara psikologis dan dampak secara biologis. Pemberhentian yang 
berdasarkan pada Undang -undang 12 tahun 1964 KUHP, harus berperikemanusiaan dan menghargai pengabdian yang diberikannya kepada perusahaan misalnya memberikan uang pension atau pesangon. Pemberhentian juga dapat diartikan sebagai pemutusan hubungan kerja seseorang karyawan dengan organisasi perusahaan. Dengan pemberhentian dilakukan berarti karyawan tersebut sudah tidak ada ikatan lagi dengan perusahaan (Hasibuan, 2016).

Pemutusan hubungan kerja merupakan fungsi terakhir manajer sumberdaya manusia yang dapat didefinisikan sebagai pengakhiran hubungan kerja antara pekerja dan pengusaha yang dapat disebabkan oleh berbagai macam alas an, sehingga berakhir pula hak dan kewajiban di antara mereka (Handoko, 2015).

\section{H. Alasan Alasan Dalam Pemberhentian}

Hasibuan (2016) menyebutkan beberapa alasan karyawan diberhentikan dari perusahaan, yaitu :

a. Undang-Undang

Undang-undang dapat menyebabkan seorang karyawan harus diberhentikan dari suatu perusahaan, antara lain anak-anak dibawah 
umur, karyawan WNA, karyawan yang terlibat organisasi terlarang.

b. Keinginan Karyawan

Terdapat berbagai alasan dari karyawan yang ingin berhenti dari pekerjaannya. Umumnya alasan berupa :

a) Pindah ke tempat lain untuk mengurus orang tua.

b) Kesehatan yang kurang baik.

c) Untuk melanjutkan pendidikan.

d) Untuk bewirausaha.

e) Balas jasa terlalu rendah.

f) Mendapat pekerjaan yang lebih baik.

g) Suasana dan lingkungan pekerjaan yang kurang serius.

h) Kesempatan promosi yang tidak ada.

i) Perlakukan yang kurang adil

c. Keinginan Perusahaan

Perusahaan juga memiliki alasan tertentu dalam memberhentikan karyawannya. umumnya disebabkan oleh: 
a. Karyawan tidak mampu mengerjakan pekerjaannya.

b. Perilaku dan kedisiplinannya kurang baik.

c. Melanggar peraturan dan tata tertib perusahaan.

d. Tidak dapat bekerja sama dan konflik dengan karyawan lainnya.

e. Melakukan tindakan amoral dalam perusahaan.

d. Memasuki masa Pensiun

Undang-undang mempensiunkan seseorang karena telah mencapai batas usia dan masa kerja tertentu. Usia kerja seseorang karyawan untuk setatus kepegawaian adalah 55 tahun atau seseorang dapat dikenakan pensiun dini, apabila menurut keterangan dokter, karyawan tersebut sudah tidak mampu lagi untuk bekerja dan umurnya sudah mencapai 50 tahun dengan masa pengalaman kerja minimal 15 tahun.

e. Meninggal Dunia

Karyawan yang meninggal dunia secara otomatis hubungan kerjanya dengan perusahaan akan terputus. Perusahaan tersebut akan memberikan 
pesangon atau uang pensiun bagi keluarga yang ditinggalkannya sesuai dengan peraturan yang ada. Seorang karyawan yang meninggal dunia saat melaksanakan tugas, pesangon atau golongannya diatur di dalam undang-undang. Misalnya, pesangon lebih besar dan golongannya dinaikkan sehingga uang pensiunnya lebih besar.

f. Perusahaan Dilikuidasi

Dalam hal perusahaan dilikuidasi masalah pemberhentian karyawan diatur dengan peraturan perusahaan, perjanjian bersama dan peraturan perundang-undangan yang berlaku. Untuk menentukan apakah benar atau tidak perusahaan dilikuidasi atau dinyatakan bangkrut harus didasarkan kepada peraturan perundangundangan.

\section{Menjelaskan Proses Pemberhentian}

Pemberhentian karyawan hendaknya berdasarkan peraturan dan perundang-undangan yang ada agar tidak menimbulkan masalah, dan dilakukan dengan cara sebaikbaiknya, sebagaimana pada saat mereka diterima sebagai karyawan. Dengan demikian, hubungan antara perusahaan 
dan mantan karyawan tetap terjalin dengan baik. Akan tetapi pada kenyataannya sering terjadi pemberhentian dengan pemecatan, karena konflik yang tidak dapat diatasi lagi, yang seharusnya pemecatan karyawan harus berdasar kepada peraturan dan perundang-undangan karena setiap karyawan mendapat perlindungan hukum sesuai dengan statusnya.

Berikut adalah prosedur/proses pemecatan karyawan:

1. Musyawarah karyawan dengan pimpinan perusahaan.

2. Musyawarah pimpinan serikat buruh dengan pimpinan perusahaan.

3. Musyawarah pimpinan serikat buruh, pimpinan perusahaan, dan P4D.

4. Musyawarah pimpinan serikat buruh, pimpinan perusahaan, dan P4P.

5. Pemutusan berdasarkan Keputusan Pengadilan Negeri

Bagi pemutusan hubungan kerja yang bersifat massal yang disebabkan keadaan perusahaan, maka sebelum pemutusan hubungan kerja pengusaha harus berusaha untuk meningkatkan efisiensi. Upaya peningkatan efisiensi yang biasa digunakan adalah dengan: 
1. Mengurangi shift kerja.

2. Menghapuskan kerja lembur.

3. Mengurangi jam kerja.

4. Mempercepat pensiun.

5. Meliburkan atau merumahkan karyawan secara bergilir untuk sementara.

Dalam pemberhentian karyawan, apakah yang sifatnya kehendak perusahaan, kehendak karyawan maupun karena undang-undang harus betul-betul didasarkan kepada peraturan, jangan sampai pemberhentian karyawan tersebut menibulkan suatu konflik suatu konflik atau yang mengarah kepada kerugian kepada dua belah pihak, baik perusahaan maupun karyawan.

Adapun bebera cara yang dilakukan dalam proses pemberhentian karyawan:

1. Bila kehendak perusahaan dengan berbagai alasan untuk memberhentikan dari pekerjaannya perlu ditempuh terlebih dahulu:

2. Adakan musyawarah antara karyawan dengan perusahaan. 
3. Bila musyawarah menemui jalan buntu maka jalan terakhir adalah melalui pengadilan atau instansi yang berwenang memutuskan perkara.

4. Bagi karyawan yang melakukan pelanggaran berat dapat langsung diserahkan kepada pihak kepolisian untuk diproses lebih lanjut tanpa meminta ijin legih dahulu kepada Dinas terkait atau berwenang.

5. bagi karyawan yang akan pensiun, dapat diajukan sesuai dengan peraturan. Demikian pula terhadap karyawan yang akan mengundurkan diri atau atas kehendak karyawan diatur atas sesui dengan paraturan perusahaan dan peraturan perundangundangan.

\section{J. Undang Undang Dan Konsep Pemberhentian}

1. Pengunduran Diri (Resignation)

Pemutusan hubungan kerja yang diawali dari pihak karyawan. Apabila hal ini terjadi di dalam masa percobaan (probation period), tidak menimbulkan masalah beban kewajiban, baik bagi perusahaan maupun karyawan. Lain halnya, bila ikatan kerja berdasarkan atas perjanjian 
(kontrak) tertentu yang memungkinkan pihak perusahaan menuntut ganti rugi biaya seleksi, pelatihan dan sebagainya.

2. Pemberhentian Sementara (lay-off)

Pemberhentian sementara (lay-off), biasa juga disebut pengrumahan, adalah pemutusan hubungan kerja yang umumnya terjadi bila terdapat situasi dan kondisi pada perusahaan :

1. Tidak ada pekerjaan yang tersedia bagi karyawan yang dirumahkan.

2. Pimpinan mengharapkan, bahwa situasi tidak adanya pekerjaan akan bersifat kontemporer dan tidak lama.

3. Pimpinan bermaksud memanggil kembali karyawan untuk dipekerjakan kembali bilamana pekerjaan tersedia kembali.

4. Pemberhentian lay-off ini terjadi pada karyawan yang masa kontraknya sudah habis.

3. Pemecatan (Disharge) 
Pemecatan merupakan pemutusan hubungan kerja yang paling drastis dan ditakuti oleh karyawan. Pemecatan dapat terjadi dikarenakan:

1) Prestasi kerja karyawan yang tidak memuaskan (kegagalan terus menerus untuk melaksanakan kewajiban yang ditugaskan atau untuk memenuhi standar pekerjaan yang telah ditetapkan).

2) Mangkir, sering terlambat, adanya sikap negatif terhadap perusahaan, atasan, atau rekan sekerja

3) Kelakuan yang tidak baik dapat diartikan sebagai perilaku yang melanggar peraturan perusahaan secara sengaja dan atas kehendak sendiri yang antara lain dapat mencakup perbuatan mencuri, berlaku kasar atau membuat gaduh dan tidak patuh. 
4. Pemensiunan (Retirement)

Retirement terjadi dikarenakan karyawan sudah mencapai umur maksimum dan masa kerja maksimum menurut batas-batas yang ditentukan oleh perusahaan dan perusahaan mempunyai kewajiban untuk memberikan tunjangan pensiun.

\begin{tabular}{|c|c|c|c|}
\hline $\begin{array}{l}\text { Sebab } \\
\text { Pemberhentian }\end{array}$ & Alasan-alasan & $\begin{array}{l}\text { Dasar } \\
\text { Hukum }\end{array}$ & Keterangan \\
\hline 1 & 2 & 3 & 4 \\
\hline \multirow[t]{3}{*}{$\begin{array}{l}\text { Keinginan } \\
\text { Perusahaan }\end{array}$} & $\begin{array}{l}\text { 1. Tidak } \\
\text { cakap dalam } \\
\text { masa } \\
\text { percobaan }\end{array}$ & $\begin{array}{l}\text { Pasal } 1603 \\
1 \text { KUHP }\end{array}$ & $\begin{array}{l}\text { Tidak diberi } \\
\text { pesangon/uang } \\
\text { jasa }\end{array}$ \\
\hline & $\begin{array}{l}\text { 2. Alasan } \\
\text { mendesak }\end{array}$ & $\begin{array}{l}\text { Pasal } 1603 \\
0 \text { KUHP }\end{array}$ & Idem \\
\hline & $\begin{array}{l}\text { 3. Pegawai } \\
\text { sering } \\
\text { mangkir/tidak } \\
\text { cakap }\end{array}$ & $\begin{array}{l}\text { a) } \\
\mathrm{P} 4 / \mathrm{M} / 57 / 6 \\
388 \\
= \\
\text { mendesak } \\
\text { b) } \\
\mathrm{P} 4 / \mathrm{M} / 57 / 6 \\
083 \\
=\text { tidak } \\
\text { mendesak }\end{array}$ & Idem \\
\hline
\end{tabular}




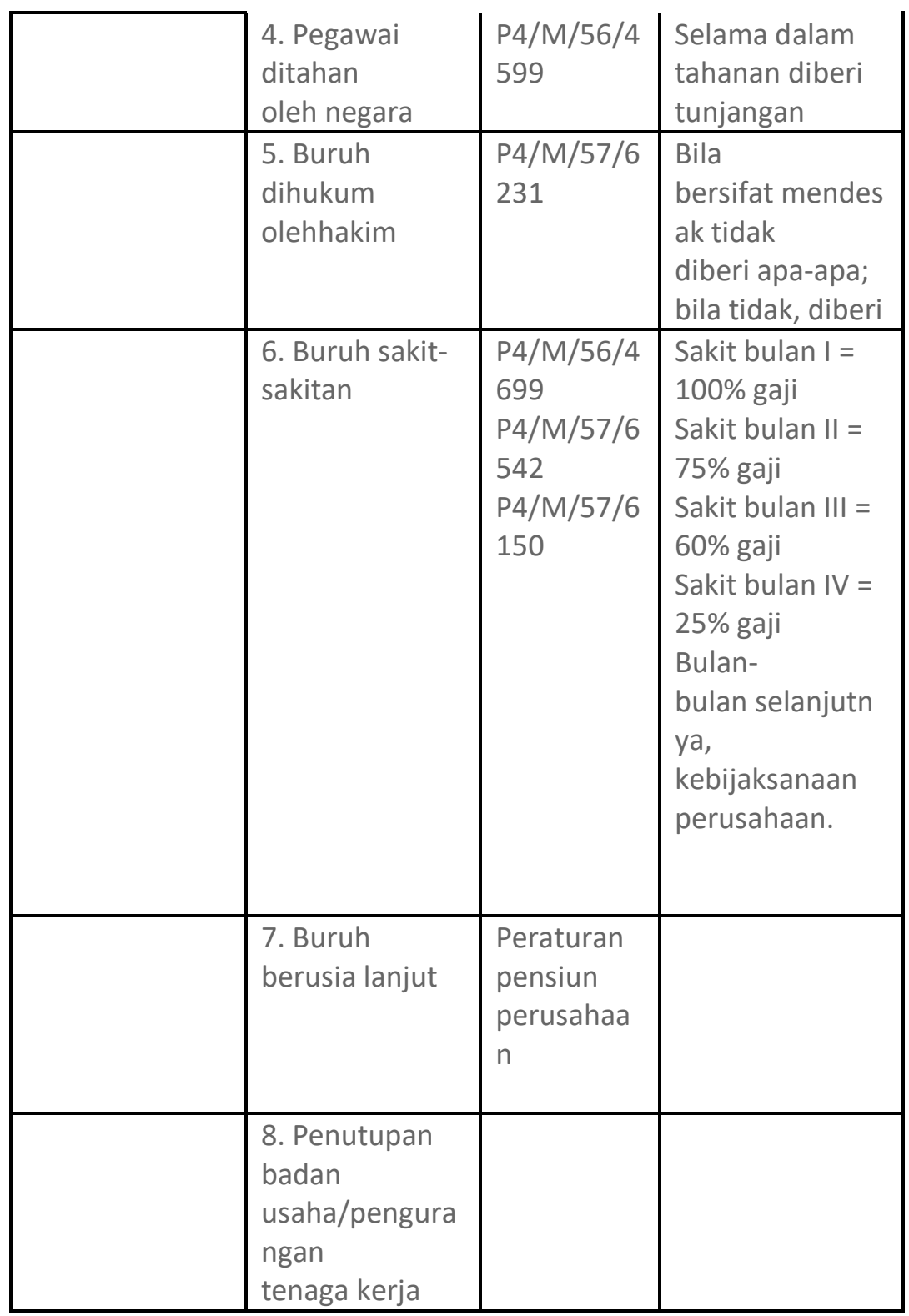




\begin{tabular}{|c|c|c|c|}
\hline \multirow[t]{3}{*}{$\begin{array}{l}\text { II. Keinginan } \\
\text { Pegawai }\end{array}$} & $\begin{array}{l}\text { 1. Tidak cakap } \\
\text { dalam } \\
\text { masa } \\
\text { percobaan }\end{array}$ & $\begin{array}{l}\text { Pasal } 1603 \\
1 \mathrm{KUHP}\end{array}$ & $\begin{array}{l}\text { Tidak diberi apa } \\
\text { apa }\end{array}$ \\
\hline & $\begin{array}{l}\text { 2. Alasan- } \\
\text { alasan } \\
\text { mendesak }\end{array}$ & $\begin{array}{l}\text { Pasal } 1603 \\
p\end{array}$ & \\
\hline & $\begin{array}{l}\text { 3. Menolak } \\
\text { bekerja } \\
\text { pada majikan } \\
\text { baru }\end{array}$ & & \\
\hline \multirow[t]{3}{*}{$\begin{array}{l}\text { III. Sebab- } \\
\text { sebab } \\
\text { lain }\end{array}$} & $\begin{array}{l}\text { 1. Pegawai } \\
\text { meninggal } \\
\text { dunia }\end{array}$ & $\begin{array}{l}\text { a) Pasal } \\
1603 j \\
\text { KUHP }\end{array}$ & $\begin{array}{l}\text { a) di luar } \\
\text { hubungan kerja } \\
\text { diberi uang } \\
\text { duka } \\
\text { pada pegawai } \\
\text { tetap }\end{array}$ \\
\hline & & $\begin{array}{l}\text { b) UU } \\
\text { Kecelakaan }\end{array}$ & $\begin{array}{l}\text { b) dalam } \\
\text { hubungan } \\
\text { kerja, ahli waris } \\
\text { dapat tunjangan }\end{array}$ \\
\hline & $\begin{array}{l}\text { 2. Berakhir } \\
\text { masa } \\
\text { hubungan kerja }\end{array}$ & $\begin{array}{l}\text { Pasal } 1603 \\
1 \\
\text { KUHAP }\end{array}$ & $\begin{array}{l}\text { Tidak diberi apa } \\
\text { apa }\end{array}$ \\
\hline
\end{tabular}




\section{K. Pemberian Uang Pesangon Dan Menentukan}

\section{Besarannya}

Konsekuensi diberhentikannya karyawan atas keinginan perusahaan adalah sebagai berikut:

1. Karyawan dengan status masa percobaan diberhentikan tanpa memberi uang pesangon.

2. Karyawan dengan status kontrak diberhentikan tanpa memberi uang pesangon.

3. Karyawan dengan status tetap, jika diberhentikan harus diberi uang pesangon yang besarnya:

a. Masa kerja sampai satu tahun: 1 bulan upah bruto.

b. Masa kerja 1 sampai 2 tahun: 2 bulan upah bruto.

c. Masa kerja 2 sampai 3 tahun: 3 bulan upah bruto.

d. Masa kerja 3 tahun dan seterusnya: 4 bulan upah bruto.

Sedangkan besarnya uang jasa sebagai berikut:

a. Masa kerja 5 s.d 10 tahun: 1 bulan upah bruto.

b. Masa kerja 10 s.d 15 tahun: 2 bulan upah bruto.

c. Masa kerja 15 s.d 20 tahun: 3 bulan upah bruto.

d. Masa kerja 20 s.d 25 tahun: 4 bulan upah bruto.

e. Masa kerja 25 tahun keatas: 5 bulan upah bruto. 


\section{Soal Soal}

1. Jelaskan makna dari pemberhentian tenaga

kerja dari sudut pandang organisasi!

2. Jabarkan alasan alasan pemberhentian dalam teori yang Anda pahami!

3. Jelaskan proses pemeberhentian SDM!

4. Jelaskan konsep pemberhentian dan apa saja UU yang mendasarinya di Indonesia!

5. Jelaskan mengenai konsep pemberian pesangon! 


\section{Pengelolaan Tunjangan}

\section{Sumber Daya Manusia}

\section{Transisi SDM}

Peran manajemen sumber daya manusia terhadap suksesnya suatu organisasi. Tingkat efektivitas mempengaruhi kinerja suatu organisasi, sebesar atau sekecil apapun organisasi tersebut. Sumber daya manusia ikut berperan dalam pengembangan strategi usaha dan menjadikan dimensi sumber daya manusia sebagai faktor yang harus ikut dipertimbangkan. Contohnya, manajer SDM untuk bagian produksi yang memiliki 600 tenaga kerja mempunyai tugas untuk membuat keputusan-keputusan mengenai alur pekerjaan, produksi, penjadwalan, dan keputusan lain yang menyangkut produksi. Hal ini bisa diartikan bahwa ia harus dapat diterima oleh para tenaga kerja bagian produksi yang sebagian besar terdiri dari tenaga kerja harian.

"Sumber daya manusia didefinisikan bukan terletak pada apa yang sumber daya manusia lakukan, tetapi apa yang sumber daya manusia hasilkan" (Melo, 2014). Karena SDM dipandang semakin besar peranannya bagi kesuksesan suatu 
organisasi, maka banyak organisasi yang kini menyadari bahwa unsur "manusia" dalam organisasi dapat memberikan keunggulan dalam bersaing. Manjemen SDM berhubungan dengan sistem rancangan formal dalam suatu organisasi untuk menentukan efektivitas dan efisiensi dilihat dari bakat seseorang untuk mewujudkan sasaran atau organisasi. Dalam suatu organisasi, manajemen SDM mencakup perekrutan, kompensasi, pelatihan, dan pengembangan.

Dalam persaingan yang semakin ketat, SDM organisasi dapat menjadi penentu tingkat kesuksesan organisasi di masa depan. Salah satu cara yang dapat digunakan organisasi dalam menarik karyawan yang berkualitas adalah dengan program kompensasi dan tunjangan yang memenuhi bermacam kebutuhan dari karyawannya. Maka dari itu, Dibutuhkan cara dalam pengelolaan dan perancangan tenaga kerja yang tepat guna, sehingga orang-orang tersebut (tenaga kerja) bias efektif dan efisien.

\section{Perspektif Strategis Pengelolaan Tunjangan}

Insentif dan tunjangan mencakup balas jasa yang dapat mempengaruhi naik turunnya prestasi kerja karyawan, 
mempengaruhi keputusan kerja dan motivasi karyawan. Maka pengaturan insentif dan tunjangan harus benar-benar adil dan layak. Maksud pokok pemberian atau penyediaan tipe insentif dan tunjangan sering disebut juga "FringeBenefit" adalah untuk mempertahankan karyawan organisasi (perusahaan) dalam jangka panjang.

Menurut Handoko (2015) tunjangan digunakan untuk membantu organisasi memenuhi satu atau lebih dari tujuantujuan berikut:

1. Meningkatkan moral karyawan

2. Memotivasi karyawan

3. Meningkatkan kepuasan kerja

4. Memikat karyawan-karyawan baru

5. Mengurangi perputaran karyawan

6. Menjaga agar serikat pekerja tidak campur tangan

7. Meningkatkan keamanan karyawan

8. Mempertahankan posisi yang menguntungkan

9. Meningkatkan citra perusahaan dikalangan karyawan

Dalam pengelolaan tunjangan untuk meningkatkan prestasi karyawan, yang perlu diperhatikan adalah beberapa faktor kompensasi yang mempengaruhii kepuasan kerja 
karyawan dan motivasi kerja secara langsung, agar dapat memaksimalkan produktivitas karyawan. Faktor-faktor tersebut antara lain bonus, pembagian laba, dan keuntungan organisasi perusahaan, serta dasar dari penetapan insentif.

a. Bonus (Reward), merupakan system imbalan uang, dan biasanya diberikan secara tunai atau deposito yang diberikan kepada karyawan di dalam organisasi.

b. Pembagian Laba (Profit Sharing), merupakan system yang mengatur bagian dari laba perusahaan yang dibagikan kepada karyawan. Biasanya dikaitkan dengan pencapaian target yang ditetapkan organisasi.

c. Pembagian keuntungan (Gain Sharing), dapat sebagai pemberian keuntungan sesudah dilakukan laporan tahunan perusahaan, di mana karyawan diberi bagian dari keuntungan, di samping keuntungan bagi para pemilik saham (owner's).

d. Sistem Insentif (Incentive System), merupakan sistem yang diketahui oleh karyawan bahwa dengan peningkatan produktivitas individu maupun kelompok akan memperoleh sejumlah insentif berdasarkan sistem insentif yang ada. 
e. Penetapan Sistem Kompensasi (Based Pay System), merupakan dasar bagi karyawan untuk mengetahui porsi kompensasi (pembayaran) yang akan diterimanya apabila karyawan di dalam melakukan tugas disertai kemampuan dan pengetahuan yang baik menyelesaikan tugasnya.

Faktor-faktor diatas dapat menjadi pendorong untuk menciptakan kepuasan dan motivasi kerja karyawan. Makin tinggi insentif yang diperoleh karyawan, akan makin tinggi kepuasan dan motivasi kerja karyawan. Kondisi tingkat kepuasan dan motivasi kerja karyawan yang tinggi akan menjadi suatu keunggulan bagi organisasi untuk bersaing. Dengan keunggulan ini, sumber daya manusia perusahaan akan dapat mengikuti perubahan dan perkembangan pasar, sesuai dengan permintaan konsumen atau pelanggan.

\section{Jenis Tunjangan waktu Bekerja}

Menurut Mangkunegara (2011), tunjangan karyawan yang masih aktif dapat dikelompokkan menjadi empat kategori anatara lain: Asuransi Sosial, Asuransi Kelompok Pribadi, Pengunduran diri, Gaji saat tidak bekerja dan kebijakan family friendly.

1. Asuransi Sosial (wajib secara hukum). 
Ketentuan UU di Amerika Serikat yaitu Social Security act 1935 mewajibkan adanya asuransi masa tua dan asuransi pengangguran. Undang-undang tersebut kemudian menambahkan asurasni untuk karyawan yang selamat dari PHK (survivor), asuransi cacat (disability), asuransi rumah sakit, asuransi medis tambahan. Karena asuransi-asuransi tersebut diwajibkan secara hukum.

Selanjutnya asuransi pengangguran yang bertujuan untuk: (1) mengganti kehilangan pendapatan selama karyawan tidak dikaryawankan oleh perusahaan, (2) membantu karyawan yang tidak bekerja menemukan karyawan baru, (3) insentif bagi perusahaan untuk menstabilkan karyawan, (4) investasi untuk mempertahankan karyawan (yang ahli) dengan memberikan pendapatan selama layoffs jangka pendek.

2. Asuransi Kelompok Pribadi

Asuransi kelompok lebih menguntungkan daripada individual karena skala ekonomis dan kekuatan tawar menawar yang lebih besar. Ada dua jenis asuransi ini yaitu: asuransi medis dan asuransi 
karena cacat.Asuransi medis adalah tunjungan yang paling penting untuk rata-rata karyawan. Asuransi ini meliputi tiga jenis biaya medis, antara lain: biaya rumah sakit, biaya operasi dan kunjungan dokter.Asuransi cacat ini meliputi: program disability jangka pendek dan program disability jangka panjang. Program jangka pendek memberikan tunjangan enam bulan atau kurang sementara itu program jangka penjang meliputi seumur hidup seseorang.

\section{Pengunduran Diri}

Perusahaan tidak wajib secara hukum untuk memberikan program pengunduran diri pribadi.Pengunduran diri ada 2 jenis:Defined Benefit :Program defined benefit menjamin tingkat tunjangan pengunduran yang telah ditentukan untuk para karyawan berdasar kombinasi antara tahun pengabdian, usia dan juga tingkat gaji karyawan.Defined Contribution :tidak seperti program defined benefit, program defined contributiontidak menjanjikan tingkat tunjangan tertentu untuk para karyawan yang mengundurkan 
diri. Tunjangan ini ditentukan untuk masing-masing karyawan sesuai dengan kontribusinya.

4. Gaji Saat Tidak Bekerja

Sepintas lalu gaji saat liburan, hari besar, cuti sakit, dan lain sebagainya terlihat tidak masuk akal secara ekonomis. Perusahaan yang membayar karyawan saat mereka tidak bekerja tidak mendapatkan nilai produksi yang nyata. Untuk itu, kebijakan cuti sakit misalnya harus distruktur dengan hati-hati untuk menghindari dalam memberi insentif yang salah pada para karyawan walaupun program-program tersebut membantu menarik dan mempertahankan karyawan.

5. Kebijakan Family-Friendly

Kebijakan ini digunakan untuk mengurangi konflik antara karyawan dan bukan karyawan terutama karyawan wanita dalam suatu organisasi yang berupa kebijakan arti keluarga dan kepedulian anak.

\section{Tunjangan Pensiun}

Di dalam proses pelaksanaannya para penerima pensiun dapat memilih salah satu dari beberapa jenis pensiun yang 
ditawarkan, dengan melihat situasi dan kondisi yang terjadi. Berikut adalah jenis-jenis pensiun yang ditawarkan oleh perusahaan:

a. Pensiun Normal.

Pensiun yang diberikan untuk karyawan yang usianya telah mencapai masa pensiun yang telah ditetapkan perusahaan. Untuk wilayah Indonesia rata-rata seseorang memasuki masa pensiun pada usia 55 tahun dan 60 tahun pada profesi tertentu.

b. Pensiun Dipercepat.

Pensiun yang dilakukan apabila perusahaan menginginkan pengurangan karyawan di dalam tubuh perusahaan.

c. Pensiun Ditunda.

Pensiun yang diminta sendiri oleh karyawan meskipun usianya belum memasuki usia pensiun. Karyawan tersebut berhenti bekerja tetapi dana pensiun miliknya di perusahaan tempat dia bekerja baru akan keluar pada masa umur karyawan ini telah memasuki masa pensiun.

d. Pensiun Cacat. 
Pensiun yang diberikan kepada karyawan yang mengalami kecelakaan sehingga dianggap tidak mampu dipekerjakan seperti semula, sedangkan umurnya belum memenuhi masa pensiun.

\section{Dana Pensiun}

Dana Pensiun adalah badan hukum yang mengelola dan menjalankan program yang menjanjikan manfaat pensiun. Yang dimaksud dengan manfaat pensiun disini adalah pembayaran berkala yang dibayarkan kepada pekerja penerima pensiun pada saat usia pensiun dan dengan cara yang ditetapkan dalam peraturan Dana Pensiun.

Berdasarkan UU No 11 tahun 1992 mengenai Dana Pensiun, di Indonesia mengenal 2 jenis Dana Pensiun yaitu:,

1. Dana Pensiun Pemberi Kerja (DPPK). Dana pensiun yang dibentuk dan dikelola oleh perusahaan pemberi kerja dan memberi program pensiun manfaat pasti dan iuran pasti bagi seluruh karyawannya.

2. Dana Pensiun Lembaga Keuangan (DPLK). Dana pensiun yang didirikan oleh bank atau perusahaan asuransi jiwa bagi masyarakat umum, baik karyawan maupun pekerja mandiri. 
Dana Pensiun diperoleh karyawan dengan mengikuti program pensiun yang diadakan oleh perusahaannya. Program pensiun adalah suatu program yang mengupayakan tersedianya uang pensiun (atau sering disebut manfaat pensiun) bagi pesertanya. Berikut adalah macam-macam program pensiun:

1. Program Pensiun Manfaat Pasti. Besar uang pensiun ditentukan berdasarkan rumus tertentu yang telah ditetapkan di awal. Rumus tersebut biasanya dikaitkan dengan masa kerja dan besar penghasilan kita.

Kelebihannya:

a. Uang pensiun ditentukan terlebih dahului, mengingat uang dikaitkan dengan gaji karyawan.

b. Dapat mengakomodasi masa kerja yang telah dilalui pekerja apabila program pensiun dibentuk jauh setelah perusahaan berjalan.

c. Pekerja lebih dapat menentukan besarnya uang yang akan diterima pada saat mencapai usia pensiun.

Kelemahannya: 
a. Perusahaan menanggung resiko atas kekurangan dana apabila hasil investasi tidak mencukupi.

b. Relatif lebih sulit untuk diadministrasikan.

2. Program Pensiun luran Pasti. Program pensiun yang menetapkan besarnya iuran yang dibayarkan pekerja dan perusahaan (pemberi kerja). Program ini terdiri dari money purchase plan, profit sharing plan dan saving plan.

Kelebihannya:

a. Pendanaan [biaya/iuran] dari perusahaan lebih dapat diperhitungkan/diperkirakan.

b. Pekerja dapat memperhitungkan besarnya iuran yang dilakukan setiap tahunnya.

c. Lebih mudah untuk diadministrasi.

Kelemahannya:

a. Penghasilan pada saat mencapai usia pensiun lebih sulit untuk diperkirakan.

b. Karyawan menanggung resiko atas ketidakberhasilan investasi. 
c. Tidak dapat mengakomodasikan masa kerja yang telah dilalui karyawan

\section{Jaminan Sosial}

Penyelenggara program jaminan sosial merupakan salah satu tangung jawab dan kewajiban Negara untuk memberikan perlindungan sosial ekonomi kepada masyarakat. Sesuai dengan kondisi kemampuan keuangan Negara, Indonesia seperti halnya berbagai Negara berkembang lainnya, mengembangkan program jaminan sosial berdasarkan funded social security, yaitu jaminan sosial yang didanai oleh peserta dan masih terbatas pada masyarakat pekerja di sektor formal.

Jaminan sosial tenaga kerja adalah suatu perlindungan bagi tenaga kerja dalam bentuk santunan berupa uang sebagai pengganti sebagian penghasilan yang hilang atau berkurang dan pelayanan sebagai akibat peristiwa atau keadaan yang dialami oleh tenaga kerja berupa kecelakaan kerja, sakit, hamil, bersalin, hari tua dan meninggal dunia. Di Indonesia, tata cara jaminan sosial diatur dalam Undangundang Jaminan Sosial Tenaga kerja, No, 3 Tahun 1992 Pasal 10.

Jenis - Jenis Jaminan Sosial tenaga kerja di Indonesia: 
1. Jaminan Kecelakaan Kerja.

Kecelakaan Kerja maupun penyakit akibat kerja maerupakan resiko yang dihadapi oleh tenaga kerja yang melakukan pekerjaan. Untuk menanggulangi hilangnya sebagian atau seluruh penghasilannya yang diakibatkan oleh kematian atau cacat karena kecelakaan kerja baik fisik maupun mental, maka perlu adanya jaminan kecelakaan kerja.

2. Jaminan Kematian.

Tenaga kerja yang meninggal dunia bukan akibat kecelakaan kerja akan mengakibatkan terputusnya penghasilan, dan sangat berpengaruh pada kehidupan sosial ekonomi bagi keluarga yang ditinggalkan. Oleh karena itu, diperlukan jaminan kematian dalam upaya meringankan beban keluarga baik dalam bentuk biaya pemakaman maupun santunan berupa uang.

3. Jaminan hari Tua.

Hari tua dapat mengkibatkan terputusnya upah karena tidak lagi mapu bekerja. Akibat 
terputusnya upah tersebut dapat menimbulkan keresahan bagi tenaga kerja dan mempengaruhi ketenagakerjaan sewaktu masih bekerja, terutama bagi mereka yang penghasilannya rendah. Jaminan hari tua memberikan kepastian penerimaan yang dibayarkan sekaligus dan atau berkala pada saat tenaga kerja mencapai usia 55 (lima puluh lima) tahun atau memenuhi persyaratan tersebut.

4. Jaminan Pemeliharaan Kesehatan. Pemeliharaan kesehatan dimaksudkan untuk meningkatkan produktivitas tenaga kerja sehingga dapat melaksanakan tugas sebaik-baiknya dan merupakan upaya kesehatan dibidang penyembuhan.

Dari pengertian diatas jelaslah bahwa jaminan sosial tenaga kerja adalah merupakan perlindungan bagi tenaga kerja dalam bentuk santunan berupa uang (jaminan kecelakaan kerja, kematian, dan tabungan hari tua), dan pelyanan kesehatan yakni jaminan pemeliharaan kesehatan. 


\section{Tunjangan Perawatan Kesehatan}

Tunjangan perawatan kesehatan merupakan bentuk paling mahal dalam area kompensasi finansial tidak langsung. Sejumlah faktor berkombinasi menciptakan biaya perawatan kesehatan yang tinggi antara lain: populasi yang menua, permintaan yang bertambah akan perawatan kesehatan, semakin mahalnya teknologi kesehatan, dan proses administrasi yang tidak efisien. Beberapa sistem perawatan kesehatan yang digunakan perusahaan di Indonesia adalah :

1. Organisasi pengelola perawatan kesehatan.

Perusahaan menjalin kerjasama dengan pihak rumah sakit beserta para dokternya setelah menyepakati harga yang harus dibayarkan.

2. Rancangan perawatan kesehatan inisiatif.

Karyawan ada posisi terbaik untuk mengetahui apa yang terbaik bagi keluarga mereka. Hal ini berbeentuk pada pembuatan investasi kesehatan yang diberikan perusahan dalam bentuk rekening kesehatan.

3. Perawatan kesehatan di tempat kerja.

Memberikan perawatan kesehatan di tempat kerja membantu menangani penyakit dan luka ringan serta memberikan perawatan lanjutan; sehingga akan 
menekan ongkos kesehatan dan kunjungan ke rumah sakit.

4. Tunjangan kesehatan utama.

Rancangan untuk menaggung biaya-biaya luar biasa yang timbul dari masalah kesehatan jangka panjang atau serius. Karyawan harus membayar dulu tagihan kesehatan sebelum asuransinya mengambil alih pembayaran.

\section{Tunjangan Finansial Lain}

Meskipun hukum mewajibkan beberapa tunjangan, organisasi-organisasi dapat secara sukarela memberikan sejumlah tunjangan lainnya. Tunjangan tersebut biasanya dihasilkan dari keputusan manajemen puncak pada beberapa perusahaan dan dari perundingan tenaga kerja/manajemen pada persuahaan lainnya. Kategori-kategori utama tunjangan tidak wajib meliputi:

a. Bayaran saat tidak bekerja.

Dalam memberikan bayaran saat tidak bekerja, pemberi kerja menyadari bahwa karyawan membutuhkan waktu untuk meninggalkan sejenak pekerjaan karena berbagai tujuan. Di bawah ini didiskusikan cuti dibayar, cuti sakit dan jeda 
dibayar, cuti panjang, dan bentuk-bentuk lain bayaran saat tidak bekerja.

b. Cuti dibayar.

Dalam Study SDM karyawan terbaru, 64 persen karyawan punya waktu memilih hari-hari cuti dibayar sebagai tunjangan kompensasi yang penting yang mereka terima. Cuti tersebut juga mendorong para karyawan untuk bertahan dengan perusahaan. Waktu cuti dibayar biasanya meningkat seiring senioritas. Namun, beberapa karyawan tampaknya memilih untuk tidak mengambil seluruh cuti mereka karena terkadang mereka merasa tertekan dengan pekerjaan meskipun sedang cuti.

C. Cuti sakit dan jeda dibayar.

Banyak perusahaan mengalokasikan kepada setiap karyawan sejumlah hari cuti sakit yang bisa mereka pergunakan ketika sakit. Beberapa manajer tidak menyukai program cuti sakit karena terkadang para karyawan menyalahgunakan sistem tersebut dengan berpura-pura sakit agar bisa cuti. Salah satu pendekatan untuk mengatasi masalah absen yang 
tidak terjadwal adalah dengan memberikan lebih banyak fleksibilitas yaitu dengan diberikannya jeda dibayar (paid time off/ PTO) sejumlah hari kosong tertentu yang diberikan setiap tahun di mana setiap karyawan bisa menggunakannya untuk keperluan apapun.

d. Cuti panjang.

Cuti panjang adalah cuti sementara dari organisasi, biasanya dengan bayaran yang dikurangi. Seringkali cuti panjang membantu mengurangi tingkat perputaran (turnover) karyawan dan menghindari para karyawan dari kelelahan.

e. Jenis-jenis lain bayaran saat tidak bekerja.

Meskipun cuti dibayar dan cuti sakit mencakup porsi terbesar bayaran saat tidak bekerja ada banyak jenis lain yang digunakan perusahaan. Seperti tugas kemasyarakatan, sebagai saksi pada pengadilani, bertugas untuk angkatan bersenjata, ataupun pada saat tejadi pemilihan umum. Perusahaan akan tetap menggaji karyawan dengan syarat mereka aktif pada kegiatan tersebut. 
f. Asuransi jiwa.

Asuransi jiwa kelompok adalah tunjangan yang diberikan oleh hampir semua perusahaan untuk melindungi keluarga karyawan saat ia meninggal dunia.

g. Relokasi.

Biaya pengangkutan barang rumah tangga dan biaya hidup sementara yang ditanggung perusahaan, mencakup seluruh atau sebagian biaya real estat yang berhubungan dengan pembelian rumah baru dan penjualan rumah yang ditinggali sebelumnya.

h. Perawatan anak.

Layanan perawatan anak bersubsidi dari perusahaan dengan tujuan meminimalisir kemangkiran ketidak hadiran dengan alasan merawat anak, memertahankan produktivitas karyawan, dan meningkatkan kemajuan kaum wanita.

i. Bantuan pendidikan.

Perusahaan memberikan bantuan berupa alokasi dana untuk meneruskan pendidikan dengan 
minimal nilai $\mathrm{C}$ dengan cara memberikan uang muka pendaftaran.

j. Layanan makanan/kafetaria bersubsidi.

Dengan adanya layanan ini, perusahaan berharap adanya balas budu karyawan yaitu dengan peningkatan produktivitas, sedikit waktu terbuang, dan tenaga kerja yang sehat. Seperti makan siang cuma-cuma yang diberikan di kantin kantor

\section{Tunjangan Keluarga}

Tunjangan Keluarga adalah tunjangan yang diberikan kepada karyawan yang memiliki keluarga. Tunjangan keluarga merupakan salah satu dari unsur gaji. Tunjangan keluarga terdiri atas Tunjangan Istri/Suami dan Tunjangan Anak.

1. Tunjangan Istri/Suami, adalah tunjangan yang diberikan kepada karyawan yang memiliki istri atau suami. Ketentuan-ketentuan yang berkaitan dengan tunjangan istri/suami adalah:

a. Diberikan untuk satu istri/suami yang sah dari pegawai negeri, yang dibuktikan dengan akta nikah dari Kantor Urusan Agama atau Kantor Catatan Sipil; 
b. Umumnya besarannya adalah $10 \%$ dari gaji pokok, atau sebesar nominal yang telah ditentukan oleh perusahaan tempat karyawan bekerja.

c. Dihentikan pada bulan berikutnya setelah terjadi perceraian atau suami/istri meninggal dunia;

2. Tunjangan Anak adalah tunjangan yang diberikan kepada pegawai negeri yang mempunyai anak (anak kandung, anak tiri, dan anak angkat).

\section{Tunjangan Waktu Libur}

Undang-Undang Ketenagakerjaan mengatur tentang cuti tahunan berbayar untuk semua pekerja/buruh yang telah bekerja selama satu tahun secara terus menerus. Pekerja/buruh berhak atas cuti tahunan selama 12 hari kerja per tahun. Pekerja/buruh yang mengambil cuti tahunan tersebut berhak atas upah penuh.

Setelah bekerja selama 6 tahun (dan kelipatannya) secara terus menerus di perusahaan yang sama, pekerja/buruh dapat diberi penghargaan berupa cuti istirahat panjang selama 1 bulan di tahun ketujuh dan tahun kedelapan, dengan ketentuan pekerja/buruh tersebut tidak berhak lagi atas cuti tahunannya dalam 2 
(dua) tahun berjalan. Ketetapan dan rincian yang mengatur hal ini diatur dalam keputusan menteri.

Pelaksanaan waktu istirahat tahunan sebagaimana ditetapkan dan diatur dalam perjanjian kerja, peraturan perusahaan, atau perjanjian kerja bersama. Di Indonesia, pengaturan tunjangan waktu libur diatur dalam Pasal 79 dan 84 UU Ketenagakerjaan (UU No. 13/2003) dan Pasal 3 Kepmenaker Istirahat Panjang Pada Perusahaan Tertentu (No.51/2004).

\section{Discretionary Benefits}

Discretionary benefits terbagi menjadi tiga kategori utama:

1) Protection Program : menyediakan manfaat bagi keluarga, memperhatikan kesehatan, perlindungan terhadap kehilangan income karena faktor catastrophic seperti pengangguran, cacat, atau sakit parah.

2) Paid Time Off : memberikan time off kepada karyawan dengan gaji seperti acara liburan

3) Services : memberikan seperti peningkatan atas biaya perkuliahan, pertukaran pembayaran, dan hari peduli 
sebagai bantuan kepada karyawan dan keluarga mereka.

\section{Administrasi Tunjangan}

Pemberian tunjangan bisa berdasarkan periode waktu (mingguan, bulanan, atau tahunan) tetapi dapat pula berdasarkan kejadian (menikah, kematian, bantuan cuti, dan sebagainya). Pemberian tunjangan juga harus diketahui dengan baik oleh semua karyawan terkait prosedur pembayaran tunjangan khususnya cara menghitungnya dan cara pemberian tunjangan misal dari absensi.

Mengenai tunjangan, disarankan agar pimpinan perusahaan mengaplikasikan tindakan - tindakan dibawah ini:

1. Sebaiknya jumlah tunjangan dikurangi macamnya, lebih sedikit tunjangan yang diberikan akan sedikit mengurangi persoalan dan pekerjaan administrasi. Untuk hal tersebut, lakukan audit tunjangan: Apakah latar belakang pemberian tunjangan? (2) Apa tujuan yang ingin dicapai? (3) Apa benar - benar berfungsi? bila tidak maka masukkan saja pada gaji pokok.

2. Lakukan survei pada perusahaan lain yang sejenis. Tunjangan apa saja yang mereka berikan? jangan 
terburu - buru untuk menghapus tunjangan bila perusahaan lain masih memberikan.

3. Apabila tunjangan dipertahankan maka harus diusahakan dalam bentuk uang, bukan dalam bentuk persen (\%) gaji pokok. Bila dari persen (\%) gaji pokok maka setiap kenaikan gaji pokok maka tunjangan akan ikut naik.

Cara mana yang digunakan tergantung manajemen perusahaan dengan mengkombinasikan dua tunjangan atau beberapa sekaligus. Faktor yang mempengaruhi keputusan misal besarnya pengupahan, jenis industri dan sebagainya. Cara apapun yang digunakan hendaknya mempertimbangkan efektivitas kebijakan tersebut dalam mencapai tujuan organisasi dan besarnya biaya sebaiknya disesuaikan dengan kemampuan perusahaan.

\section{Perspektif Stratejik Kompensasi Untuk}

\section{Menghasilkan Komitmen Karyawan}

Kompensasi (termasuk didalamnya tunjangan karyawan) adalah pengaturan pemberian balas jasa bagi karyawan, baik yang secara langsung berupa uang, maupun tidak langsung berupa balas jasa non finansial. Martochio (2015) menggunakan istilah sistem kompensasi, yaitu paket imbalan total yang diberikan kepada karyawan sebagai imbalan atas tenaga mereka. Dengan demikian, kompensasi berfungsi 
untuk mendayagunakan karyawan secara efektif guna mendorong peningkatan produktivitas kerja.

Kompensasi penting bagi karyawan sebagai individu karena besarnya kompensasi mencerminkan ukuran nilai prestasi mereka di antara karyawan itu sendiri, keluarga dan masyarakat. Kemudian program kompensasi juga penting bagi organisasi, karena hal itu mencerminkan upaya organisasi untuk mempertahankan sumber daya manusia yang dimilikinya atau dengan kata lain, agar karyawan mempunyai kesetiaan dan komitmen yang tinggi pada organisasi.

Dari berbagai hasil penelitian yang dilakukan oleh para ahli manajemen SDM menunjukkan bahwa faktor utama ketidakpuasan kerja karyawan adalah kompensasi yang tidak sesuai dengan harapan karyawan. Disamping itu adanya ketidakpuasan karyawan terhadap kompensasi yang diterima dapat mencetuskan perilaku negatif karyawan terhadap organisasi, yaitu menurunnya komitmen karyawan terhadap perusahaan.

Kondisi ini menuntut suatu organisasi untuk mengembangkan performanya, dan hal itu harus didukung pula oleh karyawan yang cakap, memiliki loyalitas serta dedikasi yang tinggi. Untuk mencapai hal tersebut, maka pemberian kompensasi yang memuaskan dapat mengurangi terjadinya turnover dan absenteeisme.

Efek lain dari ketidakpuasan karyawan terhadap kompensasi adalah dampak psikologis yang dialami oleh karyawan yang ingin keluar / resign dari organisasi. Keinginan tersebut tentunya tidak mudah untuk diwujudkan mengingat berbagai kondisi yang tidak atau kurang memungkinkan bagi 
karyawan untuk pindah dari satu perusahaan ke perusahaan lain, misalnya kondisi persaingan di pasar tenaga kerja yang semakin ketat, birokrasi serta aturan internal yang ada di dalam perusahaan itu sendiri. Akhirnya bentuk ketidakmampuan mereka untuk keluar tersebut diwujudkan dengan tidak peduli terhadap kewajiban mereka serta tidak merasa bertanggung jawab terhadap kemajuan organisasi atau dengan kata lain, mempunyai komitmen yang rendah terhadap perusahaan.

Hal ini tentu saja membawa dampak yang sangat tidak menguntungkan bagi perusahaan karena karyawan yang mempunyai komitmen yang rendah akan mengarah pada prestasi kerja dan produktivitas yang rendah pula. Kondisi karyawan yang seperti ini tidak bisa dibiarkan berlarut-larut karena dengan komitmen yang rendah, karyawan tidak bisa mencurahkan seluruh jiwa, perasaan dan waktu mereka untuk kemajuan organisasi yang pada akhirnya akan menyebabkan organisasi kehilangan daya saingnya. Oleh karena itu sikap pegawai atas kepuasan kerja dan komitmen pada organisasi telah menjadi kepentingan yang mendesak bagi ahli-ahli $p$ industri dan manajemen sumber daya manusia karena hal itu membawa dampak bagi perilaku karyawan pada organisasi.

Komitmen organisasi berkaitan dengan identifikasi dan loyallitas karyawan pada orgasnisasi dan tujuan-tujuannya. Kompensasi seringkali harus membuat organisasi harus introspeksi apalagi bila hal tersebut berakibat banyak karyawan yang mempunyai sikap acuh dengan masa depan organisasi serta tidak peduli lagi dengan lingkungan tempat kerjanya. Apabila hal tersebut dibiarkan terus berlanjut, tidak mustahil terjadi turnover yang tinggi sehingga organisasi harus 
mengeluarkan biaya yang lebih banyak untuk merekrut karyawan baru serta mengembangkan mereka. Salah satu cara untuk mengantisipasi hal tersebut adalah dengan pemberian kompensasi yang layak, wajar, dan dapat memuaskan para karyawan, sehingga tercipta komitmen organisasi yang tinggi pada karyawan

\section{Soal Soal}

1. Jelaskan kegunaan tunjangan dan kompensasi bagi kemajuan perusahaan!

2. Jelaskan jenis jenis tunjangan dalam bekerja!

3. Terangkan kegunaan dan manfaat dari pengelolaan dana pensiun dan tunjangan pensiun!

4. Jelaskan pengaplikasian jaminan sosial yang ada di Indonesia!

5. Jelaskan macam dari tunjangan keluarga!

6. Mengapa perusahaan mau mengadakan tunjangan waktu libur untuk karyawannya? Bukankan itu justru merugikan organisasi? Jelaskan jawaban Anda!

7. Apa fungsi pokok dan manfaat dari pengadaan tunjangan perawatan kesehatan bagi organisasi! 
8. Apakah Discretionary benefit yang bebannya sangat tinggi dapat memberikan manfaat bagi organisasi? Bukankan beban yang tinggi akan sangat tidak menguntungkan bagi perusahaan? Jelaskan jawaban Anda!

9. Mengapa besaran tunjangan harus diketahui oleh karyawan? Bukankah administrasinya akan menjadi lebih rumit? Jelaskan jawaban Anda!

10. Jelaskan faktor apa saja yang dapat menghasilkan komitmen karyawan pada organisasi! 


\section{Serikat Karyawan}

dan Manajemen

\section{A. Sejarah dan awal munculnya serikat pekerja}

Serikat pekerja adalah organisasi yang dibentuk dari, oleh, dan untuk Pekerja/Buruh baik diperusahaan maupun diluar perusahaan, yang bersifat bebas, terbuka, mandiri, demokratis dan bertanggung jawab guna memperjuangkan, membela serta melindungi hak dan kepentingan Pekerja/Buruh serta meningkatkan kesejahteraan Pekerja/Buruh dan keluarganya.

Jelas bahwa peningkatan kesejahteraan Pekerja/Buruh dan keluarganya sebagai tujuan utama keberadaan Serikat Pekerja/Buruh. Jika menelisik sejarah panjang munculnya Serikat Pekerja/ Serikat Buruh di Indonesia sebenarnya dimulai pada masa kolonial Belanda pada tahun 1920-an. Tujuan dan garis perjuangannya setiap dekade memang mengalami banyak perubahan. Pada awal keberadaannya kegiatan Serikat Pekerja/Serikat Buruh masih terbatas dalam usaha sosial dan olahraga dan ada kalanya ikut mencampuri 
politik sebagai usaha kaum politik dalam memperkuat untuk mengadakan pergerakan perjuangan kemerdekaan dan kebebasan dari penjajah. Dengan seiring waktu, tuntutan itu berkembang atas perbaikan nasib Pekerja/Buruh dengan kenaikan upah, tuntutan adanya jaminan sosial (kesehatan, kecelakaan kerja, hari tua, kematian dan pensiun) bagi kaum Pekerja / Buruh, dan hak-hak normatif lainnya.

Pada jaman orde baru organisasi Serikat Pekerja/Serikat Buruh dikanalisasi seolah hanya Serikat Pekerja Seluruh Indonesia (SPSI) untuk non pemerintah dan bagi Pekerja/Pegawai pemerintah bergabung ke Korps Pegawai Negeri (Korpri) dan Ratifikasi Konvensi ILOtentang kebebasan berserikat. Setelah keran demokrasi terbuka seiring tuntutan reformasi pada tahun 1998 maka paradigma mengenai organisasi Serikat Pekerja/Serikat Buruh berubah. Banyak berdiri Serikat Pekerja/Serikat Buruh di Indonesia, termasuk di lingkungan Pekerja/Karyawan BUMN. Bak jamur dimusim hujan, Karyawan dan Pekerja BUMN beramai-ramai meninggalkan KORPRI yang mempunyai stigma orde baru dengan membentuk Serikat Pekerja (SP), Serikat Karyawan (Sekar) dan perkumpulan lainnya. 


\section{B. Kerangka Hubungan Antara Serikat Karyawan, Manajemen, Dan Pemerintah}

Serikat karyawan atau union terbentuk karena para karyawan tidak puas terhadap berbagai kondisi perusahaan. Kerangka hubungan serikat karyawan dan manajemen terdiri dari 3 aktor (pemeran) utama: para pekerja dan wakil-wakil mereka (pengurus serikat), para manajer (manajemen) dan wakil-wakil pemerintah dalam bidang legislatif, yudikatif dan eksekutif. Masing-masing pihak ini saling ketergantungan, namun mereka tidak seimbang. Pemerintah adalah kekuatan dominan karena menentukan peranan manajemen dan serikat karyawan melalui hukum-hukum dalam bidang kepegawaian atau perburuhan.

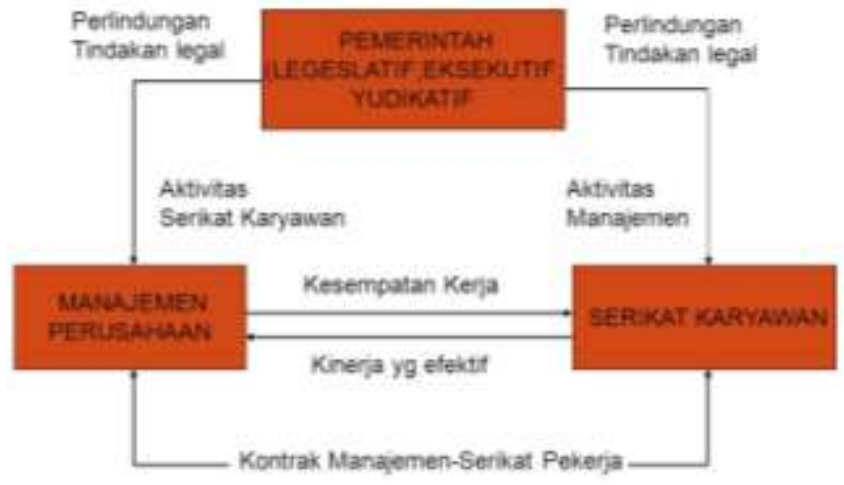

Gambar 11.1 Kerangka Hubungan 3 Pihak 


\section{Struktur Serikat Kerja}

Serikat karyawan (labor union atau trade union) adalah organisasi para pekerja yang dibentuk untuk mempromosikan atau menyatakan pendapat, melindungi dan memperbaiki, melalui kegiatan kolektif, kepentingan-kepentingan sosial, ekonomi dan politik para anggotanya. Kepentingan dominan yang diperjuangkan serikat karyawan adalah ekonomi. Contohnya adalah permintaan kenaikan gaji atau upah, pengurangan jam kerja dan perbaikan kondisi-kondisi kerja.

Ada dua konsep pergerakan serikat karyawan yang berbeda. Pertama, pendekatan business unionism. Ini misinya adalah melindungi para karyawan, meningkatkan kesejahteraan mereka, menuntut kenaikan gaji, memperbaiki kondisi-kondisi kerja dan membantu karyawan pada umumnya. Kedua, social unionism yang mempunyai misi tertuju pada kebijaksanaan-kebijaksanaan sosial, ekonomi dan politik yang lebih luas.

Tipe serikat karyawan menurut Handoko (2015):

1. Craft Unions. Terdiri dari para karyawan atau pekerja yang mempunyai keterampilan yang sama. Misalnya tukang-tukang kayu. 
2. Industrial Unions. Dibentuk berdasarkan Iokasi pekerjaan yang sama. Terdiri dari para pekerja yang tidak berketrampilan, maupun yang berketrampilan dalam suatu perusahaan atau industri tertentu tanpa memperhatikan sifat pekerjaan mereka.

3. Mixed Unions. Mencakup pekerja trampil, tidak trampil, setengah trampil dari suatu lokal tertentu tidak memandang dari industri mana. Ini adalah kombinasi serikat craft unions dan industrial unions.

Dalam strukturnya, serikat karyawan memiliki 2 bentuk (Hasibuan, 2016):

1. Serikat Karyawan Lokal. Merupakan bentuk basis organisasi buruh, dan bagian yang paling penting dari struktur serikat karyawan. Serikat karyawan lokal memberikan kepada para anggota "revenue" dan kekuatan pergerakan serikat secara keseluruhan.

2. Serikat Karyawan Nasional. Adalah serikat karyawan yang mempunyai tugas untuk mewakili karyawan dalam penyelesaian masalah-masalah yang kepentingannya bersifat nasional. 


\section{Tanggapan Proaktif Manajemen}

Manajemen perusahaan dapat mempersempit gerak serikat kerja di perusahaan mereka dengan tanggapan proaktif sebagai berikut:

1. Merancang pekerjaan-pekerjaan yang secara pribadi memuaskan para karyawan.

2. Mengembangkan rencana-rencana yang memaksimumkan berbagai kesempatan individual di samping meminimumkan kemungkinan pemutusan hubungan kerja.

3. Memilih para karyawan yang "qualified".

4. Menetapkan standar-standar prestasi kerja yang adil, mempunyai arti dan obyektif.

5. Melatih para karyawan dan manager sehingga memungkinkan mereka untuk mencapai tingkat prestasi yang diharapkan.

6. Menilai dan menghargai perilaku atas dasar prestasi kerja nyata. 


\section{E. Penyelesain Dan Mediasi Konflik Antara Serikat Kerja Dan Manajemen}

Perundingan kolektif adalah proses dimana para wakil (representatif) dua kelompok bertemu dan bermaksud untuk merundingkan (negosiasi) suatu perjanjian yang mengatur hubungan kedua pihak di waktu yang akan datang. Tipe dasar perundingan kolektif ada 2 yaitu :

1. Perundingan Tradisional. Adalah mengenai distribusi "benefit", yaitu pengupahan, kondisi kerja, promosi, pemutusan hubungan kerja, hak-hak manajemen, dan sebagainya.

2. Perundingan perundingan bersifat integratif. Ini berkaitan dengan masalah kepentingan timbal balik kedua belah pihak yang lebih besar dan terutama menyangkut upaya pemecahan masalah atau pendamaian konflik yang terjadi.

Faktor- faktor yang berpengaruh dalam perundingan kolektif seperti yang dikemukakan Handoko (2015) adalah:

a. Cakupan Perundingan.

b. Tekanan-Tekanan Perundingan Serikat Karyawan 
c. Peranan Pemerintah

d. Kesediaan Perusahaan

Proses perundingan kolektif menurut Hasibuan (2016) memiliki 3 tahap dan saling berurutan:

i. Tahap persiapan negosiasi, adalah tahap pertama dan paling kritis. Keberhasilan negosiasi secara keseluruhan, sangat tergantung pada kesiapan kedua pihak.

ii. Tahap perundingan. Negosiasi ini biasanya mencakup pengupahan, jam kerja dan kondisi kerja. Secara ringkas, pengupahan berarti semua bentuk kompensasi seperti gaji/upah, asuransi, program pensiun, dan pelayanan serta "benefit" lainnya.

iii. Tahap administrasi perjanjian. Tahap ini dilakukan untuk menjamin bahwa baik manajemen maupun para karyawan mentaati segala ketentuan yang diatur dalam perjanjian kerja. 


\section{G. Soal Soal}

1. Bagaimana dan dalam keadaan apa serikat pekerja di Indonesia pertama kali muncul? Jelaskan!

2. Jelaskan hubungan antara serikat karyawan, manajemen, dan pemerintah!

3. Jelaskan secara singkat mengenai struktur serikat kerja di Indonesia!

4. Apa yang dapat dilakukan Manajemen perusahaan untuk menghadapi Serikat Kerja? Jelaskan!

5. Terangkan bagaimana mediasi konflik dilakukan jika terjadi permasalahan antara Manajemen dan Serikat Karyawan! 


\section{BIODATA PENULIS}

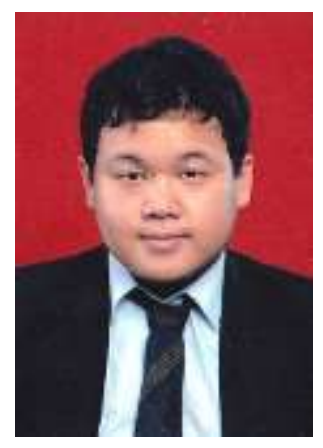

Rizky Eka Febriansah, S.Mb., M.SM. lulus S1 di Program Studi Manajemen Bisnis di Fakultas Manajemen Bisnis Telekomunikasi Universitas Telkom (UTELK) Bandung Tahun 2011. Lulus S2 di Program Magister Science Management Universitas Airlangga (UNAIR) Surabaya Tahun 2015. Saat ini, penulis adalah Dosen Tetap sekaligus menjabat sebagai Kepala Laboratorium periode 2016 - 2018 pada Program Studi Manajemen Fakultas Ekonomi dan Bisnis Universitas Muhammadiyah Sidoarjo. Mengampu mata kuliah Manajemen Sumber Daya Manusia 1, Manajemen Sumber Daya Manusia 2, dan Sistem Informasi Manajemen. Penulis aktif di dunia organisasi, terlibat pada Himpunan Pengusaha Muda Indonesia (HIPMI) dan Forum Manajemen Indonesia (FMI). Penulis juga aktif dalam menulis jurnal ilmiah dan pernah tampil pada 3 konferensi pada kurun waktu 2016 - 2017, 2 konferensi nasional dan 1 konferensi Internasional. 